\title{
Archaeological Investigations at Morgan Chapel Cemetery (41BP200), A Historic Cemetery in Bastrop County, Texas
}

Anna J. Taylor

Anne A. Fox

I. Waynne Cox

Follow this and additional works at: https://scholarworks.sfasu.edu/ita

Part of the American Material Culture Commons, Archaeological Anthropology Commons, Environmental Studies Commons, Other American Studies Commons, Other Arts and Humanities Commons, Other History of Art, Architecture, and Archaeology Commons, and the United States History Commons

Tell us how this article helped you.

This Article is brought to you for free and open access by the Center for Regional Heritage Research at SFA ScholarWorks. It has been accepted for inclusion in Index of Texas Archaeology: Open Access Gray Literature from the Lone Star State by an authorized editor of SFA ScholarWorks. For more information, please contact cdsscholarworks@sfasu.edu. 


\section{Archaeological Investigations at Morgan Chapel Cemetery (41BP200), A Historic Cemetery in Bastrop County, Texas}

\section{Creative Commons License}

\section{(c) (1) (8)}

This work is licensed under a Creative Commons Attribution-NonCommercial 4.0 International License 


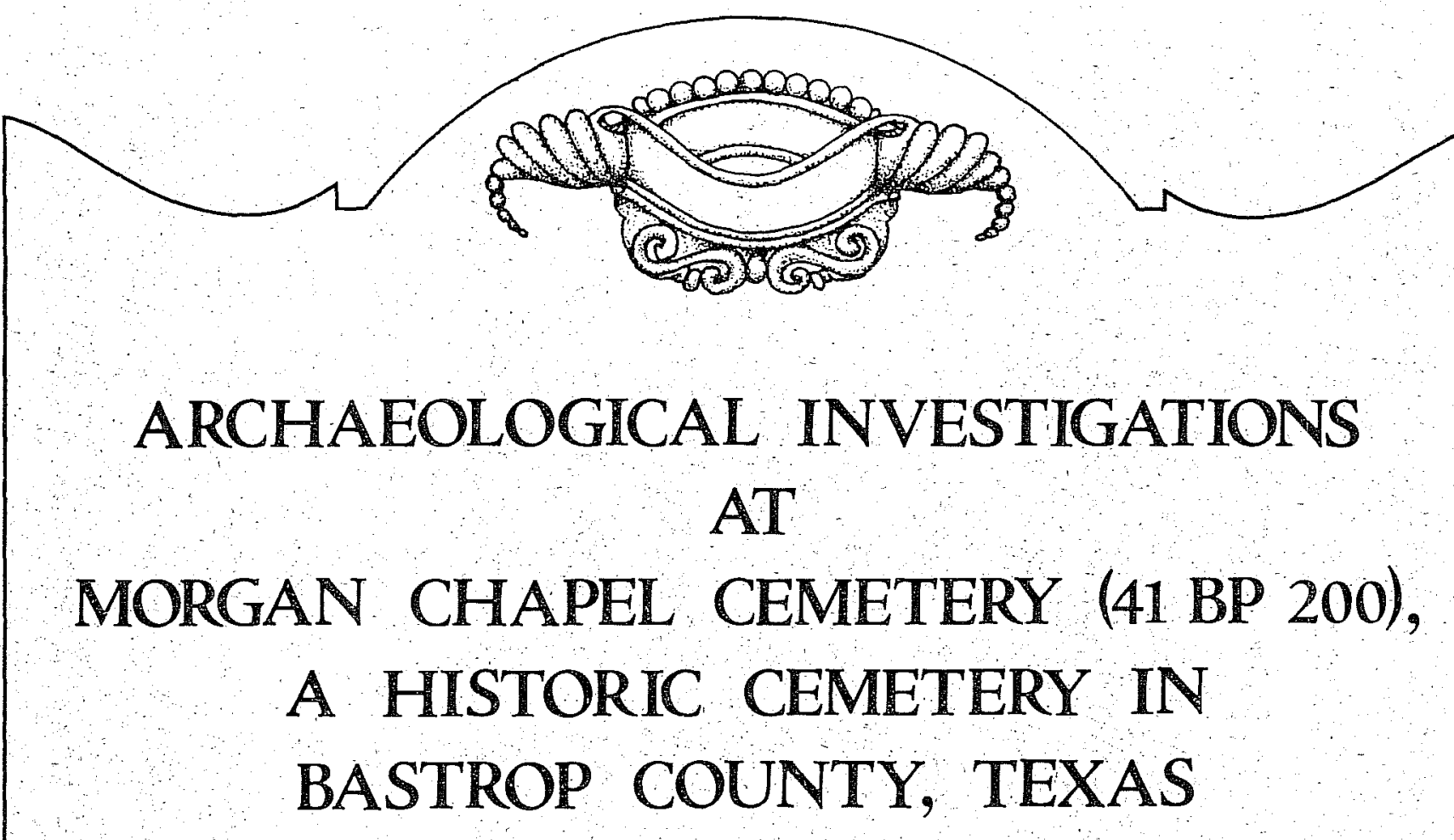

Anna J.Taylor, Anne A. Fox, and I. Waynne Cox

With Appendices By

Virginia K. Massey and

Richard G. Holloway

Center for Archaeological Research

The University of Texas at San Antonio

Archaeological Survey Report, No.146

1986 


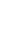




\section{UTSA - Center for Archaeological Research}





\section{ARCHAEOLOGICAL INVESTIGATIONS \\ AT \\ MORGAN CHAPEL CEMETERY (4I BP 200), \\ A HISTORIC CEMETERY IN \\ BASTROP COUNTY, TEXAS}

Anna J. Taylor, Anne A. Fox, and I. Waynne Cox

With Appendices by

Virginia K. Massey and

Richard G. Holloway

Center For Archaeological Research The University of Texas at San Antonio ${ }^{\circ}$

Archaeological Survey Report, No. 146 
The following information is provided in accordance with General Rules of Practice and Procedure, Chapter 41.11 (Investigation Reports), Texas Antiquities Committee:

1. Type of investigation: Archaeological investigation at the Morgan Chape 1 Cemetery;

2. Project name: CPS-Butler, Phase III: Morgan Chapel Cemetery;

3. County: Bastrop County, Texas;

4. Principal Investigator: Thomas R. Hester; Co-Principal Investigators: Jack D. Eaton and Kenneth M. Brown;

5. Name and location of sponsoring agency: City Public Service, San Antonio, Texas;

6. Texas Antiquities Committee Permit No. 364 ;

7. Published by the Center for Archaeological Research, The University of Texas at San Antonio, San Antonio, Texas 782850658, 1986.

A 1 ist of publications offered by the Center for Archaeological Research can be obtained by sending $\$ 1.00$ to the Center for Archaeological Research, The University of Texas at San Antonio, San Antonio, Texas 78285-0658. 
During August 1984, archaeologists from the Center for Archaeological Research (CAR), The University of Texas at San Antonio, and City Public Service (CPS) of San Antonio relocated the burials from Morgan Chapel Cemetery (41 BP 200), in Bastrop County, Texas. Twenty-one burials, of which 13 were unmarked, were located, exposed, recorded, and removed for reinterment in the nearby McDade and Ridgeway Cemeteries. The nature of the clay subsoil at the site obscured grave out 1 ines, which made detection of unmarked burials quite difficult. This situation resulted in a decision by CPS, following consultation with representatives of the Texas Historical Commission and the CAR-UTSA archaeologists, to remove all the soil from the 3.055 acres of cemetery property to a depth of six feet. The excavation procedures utilized during the cemetery removal, and problems encountered during this process, are detailed to aid other archaeologists involved in similar projects. Descendants of the deceased and also other local informants provided details about the identification and location of burials. Information concerning the burial customs and physical condition of the people of this area was gained as a result of the project. Because the cultural deposits and features associated with Morgan Chape 1 Cemetery were removed during the cemetery operations, and no in situ cultural deposits remain, the site is no longer considered to be a significant cultural resource. The suggestion is therefore made that the site not be recommended for nomination as a State Archeological Landmark, or 1 isted on the National Register of Historic Places. Investigations were done in comp 1 iance with Texas state statutes governing cemeteries. 


\section{TABLE OF CONTENTS}

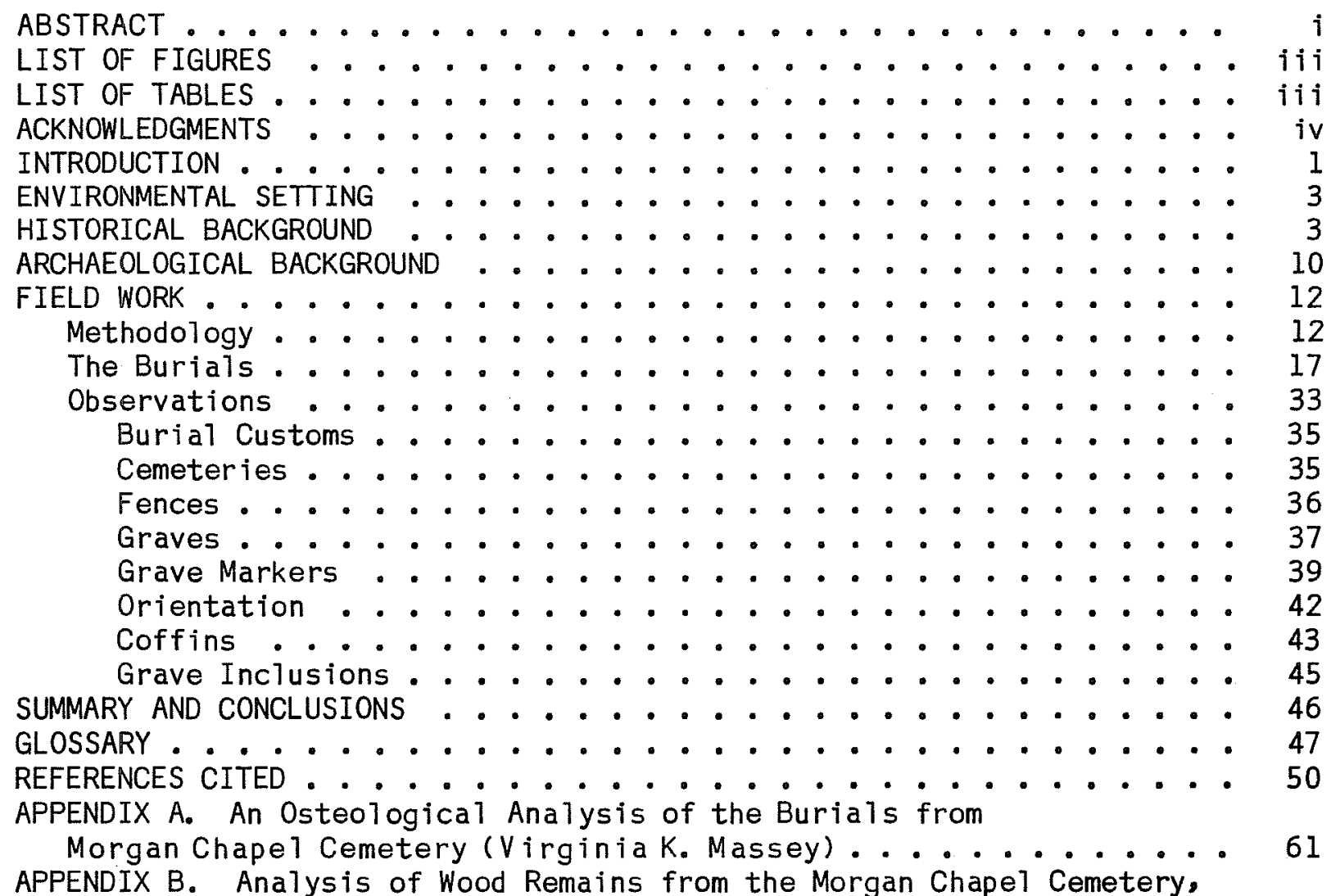

41 BP 200 (Richard G. Holloway) . . . . . . . . . . . . 73 


\section{LIST OF FIGURES}

1. Map of the General Morgan Chapel Cemetery (4I BP 200) Area . . . 2

2. View of Morgan Chapel Cemetery (41 BP 200) Before Excavations, and of an Exposed Dug Vault . . . . . . . . . . . . . . . 5

3. Map of the Immediate Morgan Chapel Cemetery (4I BP 200) Vicinity . 6

4. Map of Morgan Chape1 Cemetery (41 BP 200) Showing Grave Locations, Coffin Forms, Age Groups, and Features . . . . . . . . 9

5. Coffin Hardware from Graves A and B . . . . . . . . . . . 22

6. Coffin Hardware from Graves C, E, G, H, and K........... 24

7. Coffin Hardware from Graves $L, N, 0$, and $T$. . . . . . . . . 29

8. Coffin Hardware from Grave M . . . . . . . . . . . . . 31

9. Metal Hardware from Grave U................. . 34

10. Coffin Shapes and a Dug Vautt Grave from Morgan Chapel Cemetery

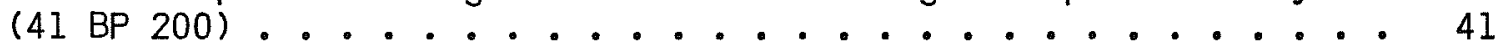

11. Microphotographs of the Coffin Wood Sample of cf. Prunus from Grave U....................... . 75

\section{LIST OF TABLES}

1. Listing of the Morgan Chapel Cemetery Burials by Age, Sex, Birth, and Death Dates, and Associated Burial Goods .........

2. Listing of the Morgan Chapel Cemetery Burials by Presence of Gray Sandy Soi1, Coffin Box or Vault Planking, Coffin Shape, Painted Coffin, Lined Coffin, and Glass Front or Sealer . . . . . . . 19

3. Listing of the Morgan Chapel Cemetery Burials by Coffin Measurements; the Depth (Below Ground Surface) of the Vautt, Coffin Box or Coffin Top; and the Depth (Below Ground Surface) of the Coffin Bottom .................... 20

4. Listing of the Calcium Levels for the Gray Sandy Soils from Graves I, J, M, O, and P, at Morgan Chapel Cemetery . . . . . . 38

5. A Summary of the Osteological Findings from Morgan Chapel Cemetery ......................... 64

6. Results of Burial Wood Analysis, 41 BP 200 . . . . . . . . . 74 


\section{ACKNOWLEDGMENTS}

We are especial1y grateful to the descendants of the deceased who visited Morgan Chape 1 Cemetery during the relocation activities. Their interest and support for our efforts, and the information they provided about the deceased were appreciated.

We wish to thank Cindy Sou lé, Martin Clausewitz, and Fritz Ranner of City Public Service for their part in accomplishing the relocation of Morgan Chape 1 Cemetery. James Odiorne, the Methodist Church legal representative, provided assistance and advice. The mortician assigned to the project, J. E. McIntire, representing the Newby Funeral Home, Inc., in Elgin, assisted in the location and exposure of the burials, and provided information about burial customs. The other personnel from the Newby Funeral Home, Inc., Margaret Newby, Myron Peterson, and Lawrence Matetzschk, were also helpful. $\mathrm{Jim}$ and John Owen, the machine operators from D\&M Services of New Braunfels, and also Calvin and Richard Taylor of Taylor Bros. Dirt Construction \& Pipe Line Inc.s and the operators with Taylor Bros. of Giddings were very responsive and helpful throughout the project, which certainly made our work much easier. The surveyor, Barry White of Giddings, provided an excellent map of the site. The various Methodist representatives assigned to the project were also helpful.

LaVerne Herrington, Pau 1 White, and Nancy Kenmotsu of The State Agency for Historic Preservation of the Texas Historical Commission (THC) in Austin provided valuable information and support throughout the project.

The archaeological field crew included the field director, A. J. Taylor, and I. Waynne Cox, both research associates (CAR-UTSA); Elizabeth Craig, Jeff Huebner, and Kevin Jo11y, archaeological assistants (CAR-UTSA); and Darla Cox of San Antonio, who volunteered to assist with the excavations. Virginia Massey, of Texas A\&M University, was the physical anthropologist for the project. Richard G. Holloway, of Texas A\&M University, analyzed the wood remains. Anne Fox (CAR-UTSA) provided valuable advice concerning excavations at the cemetery, and analyzed fabric samples from the burials. Dr. Donald R. Lewis (CAR-UTSA) provided information concerning the nature of the soils at the site, and the soil test results. David Hafernik and Bruce Ellis did the drafting for the report, and Margaret Greco did the artifact illustrations. Special thanks are due to Mary Lou El1is, administrative secretary, Sharon Quirk, editor, and Ann Young, typist (a11 from the CAR-UTSA), a 11 of whom provided much support and aid throughout the project. Thomas R. Hester (principal investigator) and Jack D. Eaton and Kenneth M. Brown (co-principal investigators) supervised the project. 


\section{INTRODUCTION}

From August 5 through August 28, 1984, archaeologists from the Center for Archaeological Research, The University of Texas at San Antonio (CAR-UTSA), and a physical anthropologist from Texas A\&M University, assisted by representatives from The State Agency for Historic Preservation of the Texas Historical Commission (THC), monitored and assisted in the relocation of all burials from Morgan Chapel Cemetery (41 BP 200) in Bastrop County, Texas (Fig. 1). The 3.055-acre property within which the cemetery was 1ocated was to be sold by the Methodist Church to City Public Service (CPS) of San Antonio. This anticipated transfer of property prompted the cemetery removal, as prescribed by Texas 1 aw, since CPS anticipates mining 1 ignite in this area, which would adversely affect the cemetery (see Texas Historical Commission 1981:2).

The Methodist Church was also concerned with the maintenance of the graves at Morgan Chapel Cemetery, which had been neglected in recent times, and favored the removal of the burials to cemeteries which were maintained. The cemetery relocation project was an extension of the CPS-But1er, Phase III project, which was conducted by Kenneth Brown (1986) of the CAR-UTSA. Archaeological investigations were conducted during the cemetery relocation in compliance with Texas state statutes governing cemeteries. Representatives from the THC observed the cemetery relocation in anticipation of 1 ater federal involvement in this area. The investigations were carried out under Texas Antiquities Committee Permit No. 364. At the time of the investigation, no federal action was pending. However, eventually there will be federal involvement, and this report wil1 come under federal review. At that time, this project would be in compliance with the National Historic Preservation Act of 1966, the National Environmental Pol icy Act, Executive Order 11593 or any other pertinent federal $1 \mathrm{aw}$.

At the request of CPS the archaeologists and the physical anthropologist participated in relocating the cemetery burials, with the direction of THC personnel to ensure complete documentation and removal of the burials. The excavation techniques utilized to detect the cemetery graves were determined by CPS in consultation with the archaeologists. Morgan Chape 1 Cemetery was found to contain a total of 21 burials of which only eight were marked.

Since the participation of archaeologists in the relocation of historic cemeteries is a relatively recent development, it is hoped that the recounting of the procedures employed as the cemetery excavations developed will be useful to other archaeologists and planners who participate in future investigations of this nature. In deference to the feelings of the descendants of the exhumed individuals, photographs of the exposed burials are not included in this report. Photographs were taken of each burial, however, and are on $f i l e$ with the other records for the project at the CARUTSA. Samples taken of coffin and vault wood, and of fabric from the burials, are curated at the CAR-UTSA. A glossary of certain terms used in the burial descriptions is provided at the end of this report. 


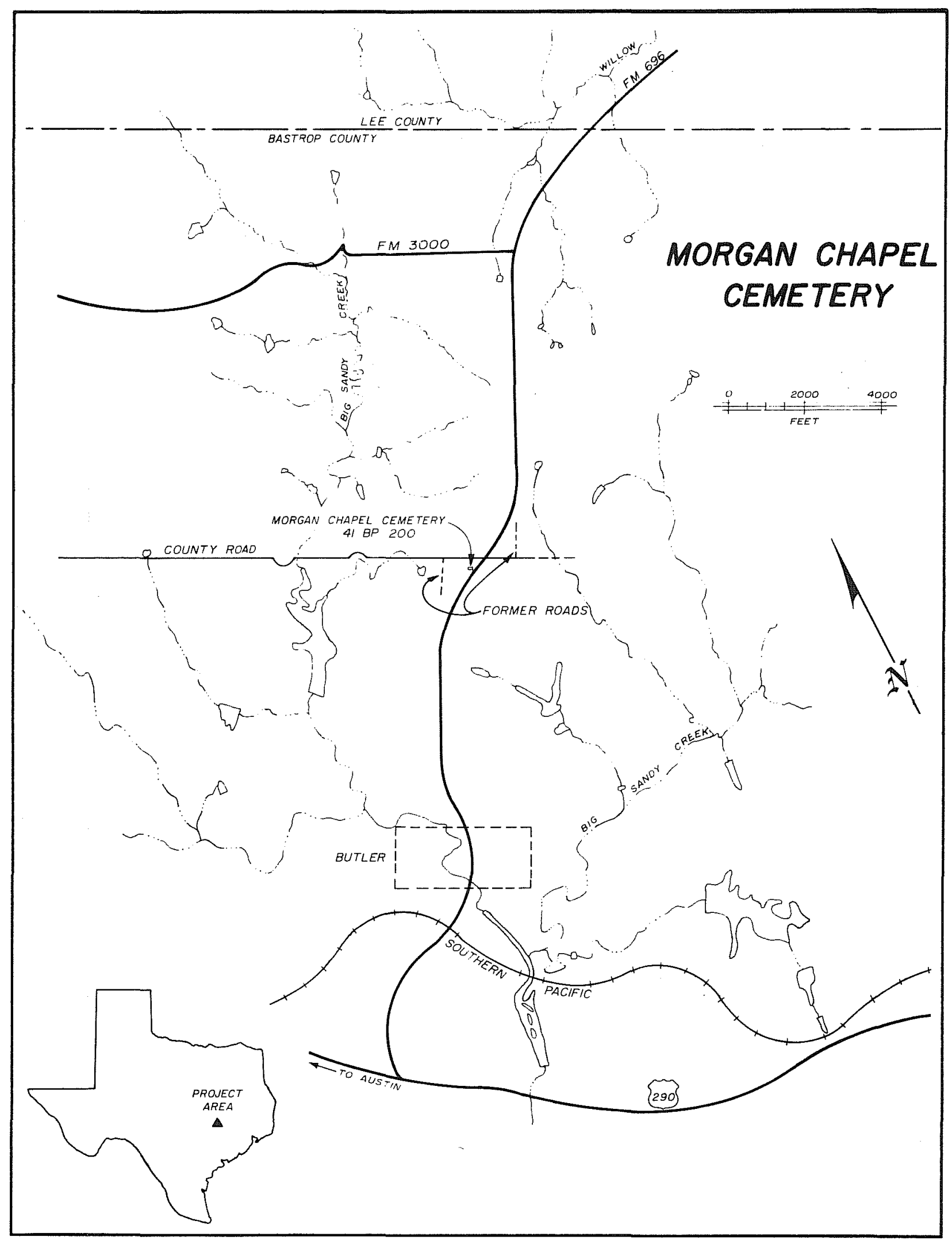

Figure 1. Map of the General Morgan Chapel Cemetery (41 BP 200) Area. 


\section{ENVIRONMENTAL SETTING}

The project area is in Bastrop County, which is predominantly within the Post Oak Belt or Savanna geographic region, with the western edge of the county occurring within the Blackland Prairie. Bastrop County is mainly within the Oak-Hickory Forest vegetation region, though the western part is in the B 1 ack 1 and Prairie. The average annual precipitation is 34 inches (Gould 1969; Arbingast et a 1. 1973; Poo 1 1975).

The area soils include Demona, Axte11. Crockett, Tabor, and Sayers loamy fine sands and fine sandy loams, with Axtell soils occurring in the project area. These loose sandy upland soils developed on a compact clay or sandy clay substrate that varies in color from a bright orange to a blue gray and is mottled with orange. Axtell soils have a surface layer of fine sandy loam; and lower 1 ayers of acid, mottled clay or sandy clay with moderate to high shrink-swel1 potential. The project area substrate is the Calvert Bluff formation (Bureau of Economic Geology 1974; United States Department of Agriculture 1979:3, 6-9, Tables 6, 9, Map Sheet 4.). Elevations in the area range from 470 to 560 feet above mean sea level (MSL).

\section{HISTORICAL BACKGROUND}

The project area was main 7 y settled by Anglo-Americans, many of whom came from the upland South. Wends, a group of S1avs in Germany, most of whom were Lutherans, predominantly settled to the east of the project area, in much of Lee County. Germans and Swedes settled to the northwest in Williamson County, and to the west in northeastern Travis County (Webb Vo1. 2 1952:879; Arbingast et a1. 1973:42; Brown 1986).

Morgan Chapel Cemetery was located to the south of Morgan Chape 1 in a grove of medium- to 1 arge-sized oak trees (Fig. 2,a). The church and the associated cemetery were located on a gentle southern slope, approximately $1.45 \mathrm{mil}$ es east of Sandy Creek ( $F$ ig. 1 ). The site was a long the northwest side of FM 696, and was approximately 370 feet south of an improved dirt road. A county road, which was abandoned after FM 696 was built, was 1ocated 750 feet west of the church (Fig. 3). Morgan Chapel was approximately 1.9 miles south-southwest of the former Mt. Pleasant Church (the Mt. Pleasant structure burned to the ground in 1984). Morgan Chapel was a smal1 Methodist Church which was probably founded in the 1870s, and was named after the Reverend Daniel Morgan of Elgin (McCrary 1955:40). The church was established by 1869, and the earliest recorded burial was that of Jane Ivy (Grave H) in 1891. Among the builders of the church were William Cruse, who was buried in the Morgan Chapel Cemetery (Grave A), and John Myers, the husband of Carol ine Myers (Grave G) who was al so buried there. The church and cemetery were reported 1 y 1 ocated on donated community property (Casey 1980). Morgan Chapel was part of a three church circuit visited by a traveling minister. Like the nearby Mt. Pleasant Church, Morgan Chapel also served as a school during the 1880s and the 1890s (Kelly and Roemer 1981:1418; Brown 1986).

The Newby Funeral Home, Inc.s in Elgin has records (dated 1911-1950) of four Morgan Chapel Cemetery burials. The records were kept by the former Miller 
Figure 2. View of Morgan Chapel Cemetery (41 BP 200) Before Excavations, and of an Exposed Dug Vault.

a, view of Morgan Chapel Cemetery prior to excavations with the Ivy and Myers family plot in the foreground, and the Cruse family plot in the background; the Grave E brick false crypt, and Grave $F$ are $v i s i b l e$ in the right central part of the photograph. Facing southeast;

b. view of the Grave $M$ collapsed dug vault planking. The head of the coffin is exposed and is in the lower central part of the photograph. Facing east. 


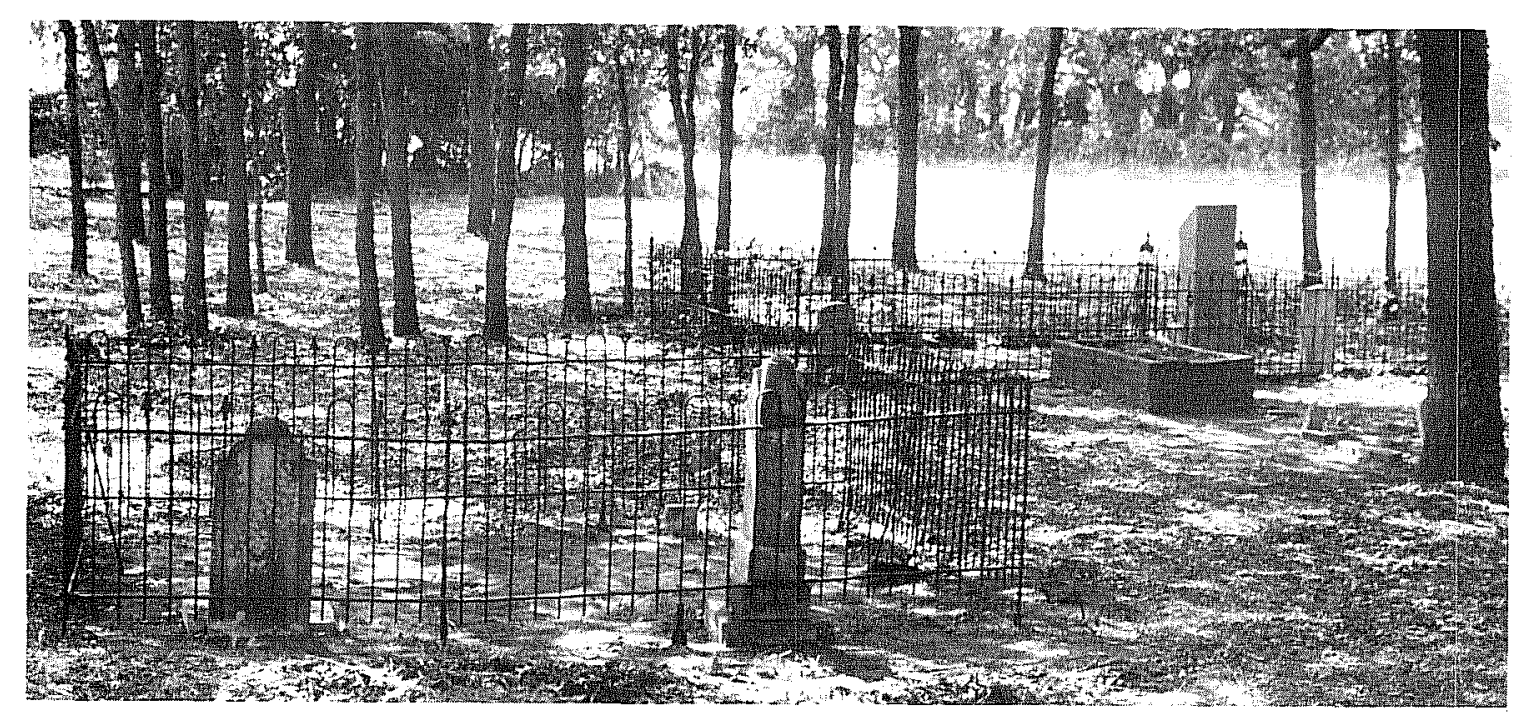

\section{$a$}

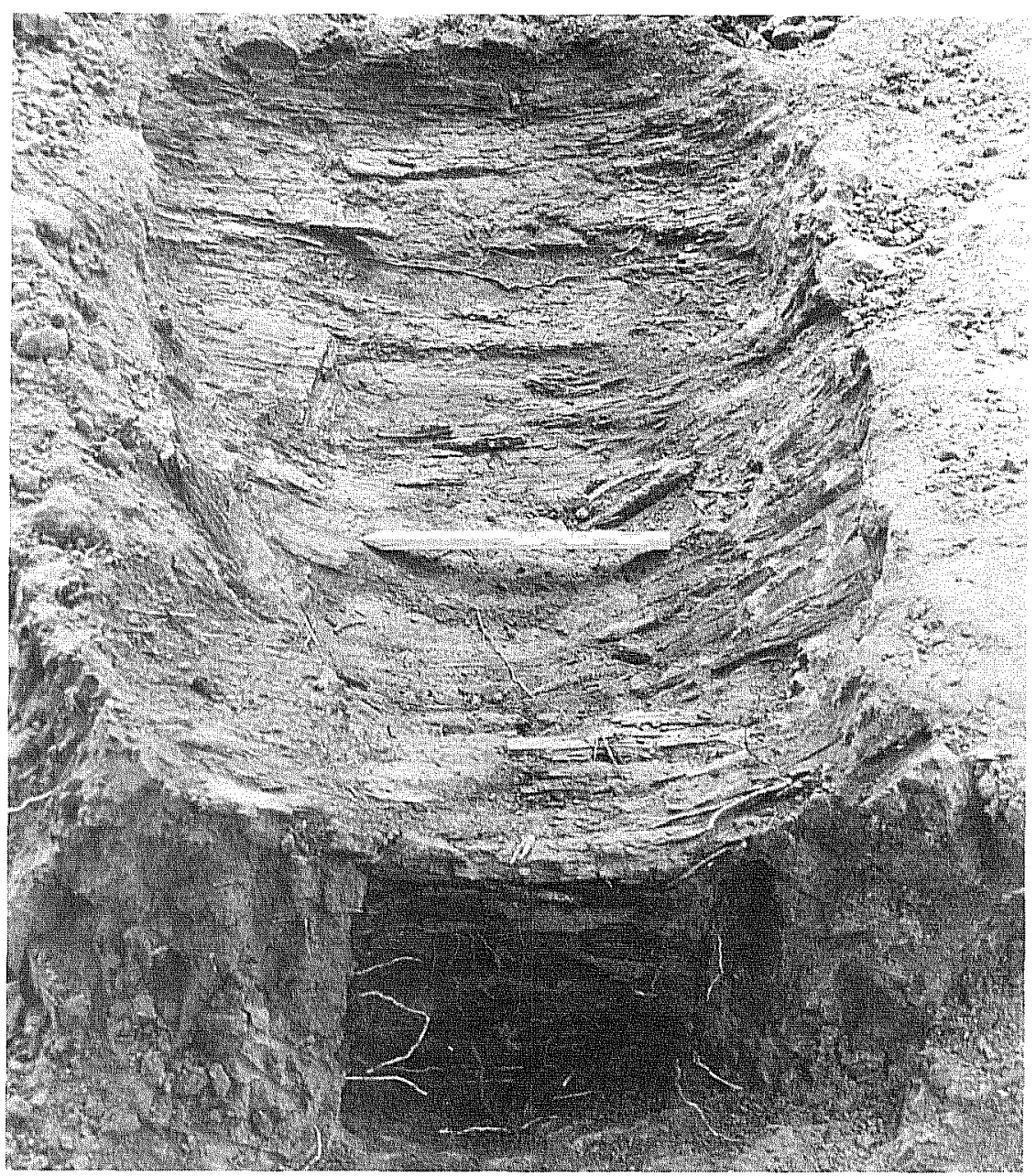




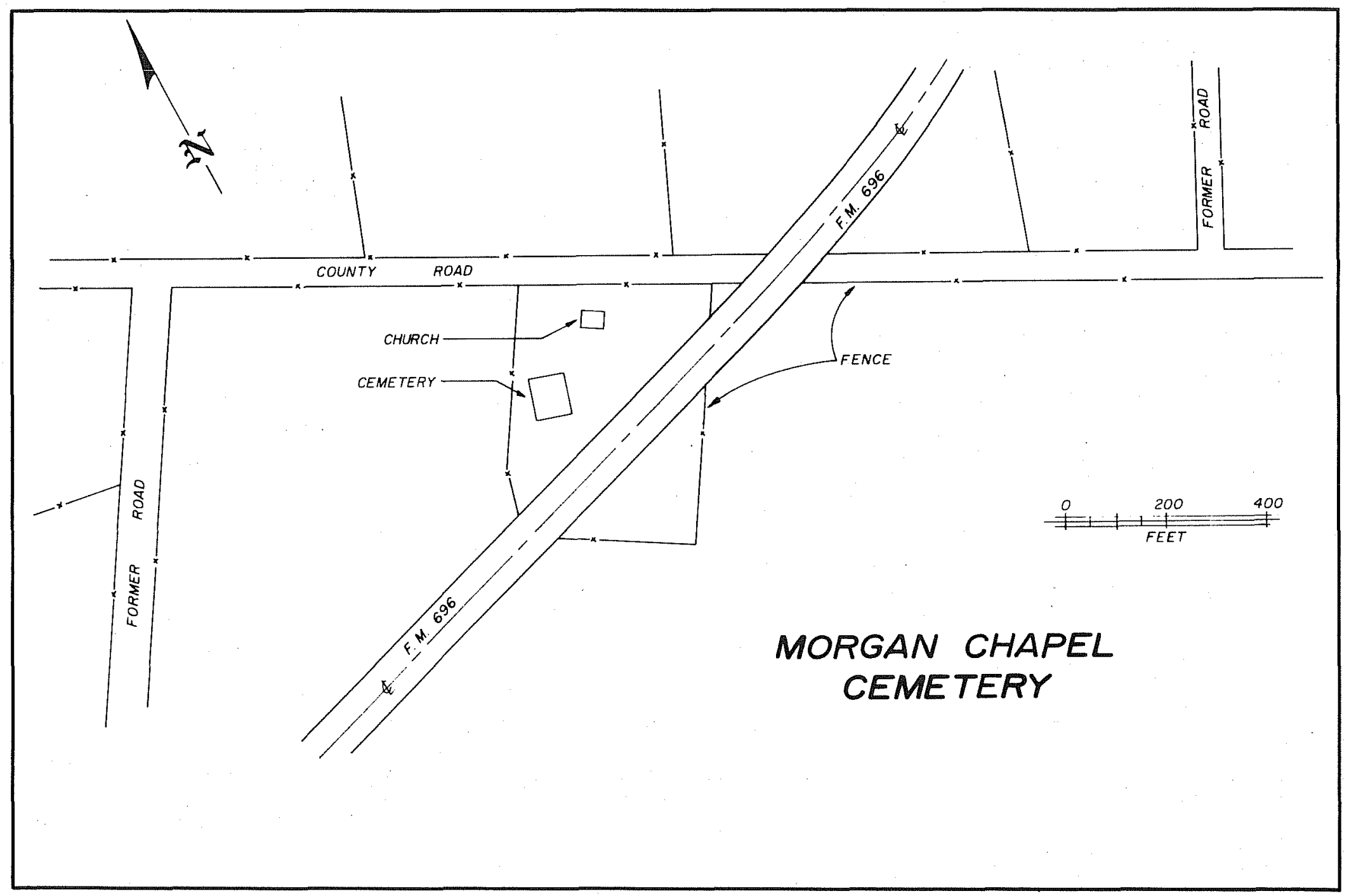

a

Figure 3. Map of the Immediate Morgan Chapel Cemetery (41 BP 200) Vicinity. 
Funeral Home of Elgin. Texas, which was established during the early 1900s and continued in business unti 1 1966, when it became the Newby Funeral Home, Inc. (Newby 1984). The names of those individuals buried in the Morgan Chapel Cemetery, and associated information are as fol 1ows:

(1) Beatrice Finnagin, 20 years 01d, white, appendicitis, September 24, 1924;

(2) W. F. Cruse, 81 years old, white, old age, Apri1 5, 1924;

(3) Infant of Duke Dunbar, stil1born, December 11, 1926;

(4) Baby Dunbar (Duke Dunbar), stillborn, October 2, 1937.

A family plot for five members of the Dunbar family was also reported by $H_{\text {. }}$ D. Dunbar (Odiorne 1983) for the cemetery. Those individuals and associated information are as follows:

(1) Virginia Elizabeth Hewitt Biggers, 36 years o1d, 1866-1902;

(2) Mable Elizabeth Dunbar, 2 years and 4 months $01 d$, June 13, 1906October 22, 1908;

(3) Barney Elbert Dunbar, 9 months old, November 25, 1908-August 8, 1909;

(4) Junior Dunbar, stillborn, December 11 or 12, 1926;

(5) Baby Dunbar, stillborn, October 2, 1937.

Virginia Biggers was the grandmother of Mable, Barney, and Junior Dunbar, and was either the grandmother or great-grandmother of Baby Dunbar. The Dunbar burials were 1 ined with brick and tile, and were grouped together in a row, according to H. D. Dunbar (Odiorne 1983). The 1 ine of burials was described to the CAR-UTSA archaeologists and the CPS representatives by H. D. Dunbar (the grandson of Virginia Biggers) as being east to west, which would make the alignment of the graves north to south, in contrast to the standard east to west orientation. J. Biggers (another relative of the Dunbar family), however, recalled that the orientation of the graves was east to west. The graves were described at various times as being northwest, south, southwest, or west of the Cruse family plot (Graves A-D) and Grave F; the exact location varied between informants (a total of four locations was given), but the graves were consistentiy denoted as being in the western vicinity of the cemetery. At least four of the five burials had wooden coffins, according to H. D. Dunbar (1984; Odiorne 1983; Biggers 1984; Casey 1984; E1gin Courier 1984e).

The location and number of graves in the Morgan Chape 1 Cemetery reported by local informants highly differed, with the highest estimate reported to the archaeologists as 110 burials (see Austin American-Statesman 1984; The Bastrop Advertiser \& County News 1984a, 1984b; The Bastrop County Times 1984). Burials were reported by $10 \mathrm{cal}$ residents as being to the east, south, and west of where the 21 burials were found. Brickworkers and their families, especial1y children, were reportedly buried in Morgan Chapel Cemetery (Casey 1980). A Mexican man, hired to cut wood for a 1 ocal inhabitant in the $1920 \mathrm{~s}$, reported $7 \mathrm{y}$ died at that time and was buried in an isolated area east of the other burials in Morgan Chapel Cemetery, which might current $1 y$ be beneath Highway 696 or along the highway right of way (Casey 1980, 1984). A few people mentioned hearing accounts of burials, (possibly Hispanic) Tocated beneath Highway 696, including stories of 
portions of the highway sinking--supposed ly because of underlying burials (Casey 1980; Kel1y and Roemer 1981:15).

Alton Greenhaw of McDade recalled attending the funeral of an infant who was buried at the Morgan Chape 1 Cemetery. The infant's coffin was taken to the graveyard in the Greenhaw's surrey, and was carried on the 1 aps of Greenhaw's brothers. The name of the infant's parents may have been King, and they divorced after the baby was born (E1gin Courier 1984b).

Ela Casey of Elgin remembered the burial of a baby in Morgan Chapel Cemetery, which belonged to a family (name unknown) that was only passing through the area. Mrs. Casey and her mother helped with the funeral preparations and attended the services at the church (Casey 1984).

The latest burial at the cemetery for which there are records was a stillborn infant, possibly the son of Duke Dunbar, who died on October 2, 1937 (Miller Funeral Home Records 1911-1950). This burial was reportedly placed in the Dunbar family plot (Odiorne 1983; Dunbar 1984). It was possibly after this final buria1, perhaps in the 1940s or 1950s (Biggers 1984), that cemetery maintenance ceased. Records indicate that the church disbanded in the 1930s, and the wooden structure was sold for scrap lumber in 1941 (McCrary 1955:40).

Local informants told the archaeologists that a "squatter" named Phillips settled on the property in the late 1940s or 1950s, after the church was abandoned, with hopes of claiming the land. During his stay, hogs were kept within the cemetery area, and gravestones were removed from the ir place and dumped in a nearby gul1y south of the cemetery (Hoerman 1980; McWi11 iams 1984).

By the time that the CAR-UTSA archaeologists $v i s i t e d$ the site (Kel $1 y$ and Roemer 1981; Brown 1986), it was overgrown with brush, and the graves were barely visible. There were two family plots located, one for four members of the Cruse family (Graves A-D) and the other for Jane Ivy (Grave H) and her daughter Caroline Myers (Grave G); all were defined by ornate iron fences. Interestingly, the iron fence around the Cruse family plot had a gate along the southern side of the plot, but there was no gate or any other entrance way into the fence around the Ivy and Myers plot. When the fence surrounding the Ivy and Myers plot was removed, remains of an earlier iron fence were found, so perhaps the original fence around this plot was not closed. There was a space between the central graves (Graves B and $C$ ) in the Cruse family plot, which was suspected to contain an additional burial, but it proved to be only an empty space between graves. Bricks were placed around the exterior of the fence around the Cruse family plot. Another iron fence, which was stolen sometime between 1950 and 1960, was reportedly west of the Ivy (Grave H) and Myers (Grave G) family plot (Biggers 1984), and a wooden fence was reported to have formerly been around an unknown man's grave (Casey 1984).

Stray bricks and two major patches of volunteer irises were found in the vicinity of the remaining marked graves (see Fig. 4). One juniper tree was located along the western part of the concentration of burials. A rough north to south alignment of large post oak trees near the eastern limits of the concentration of burials may have once marked one side of the cemetery. 


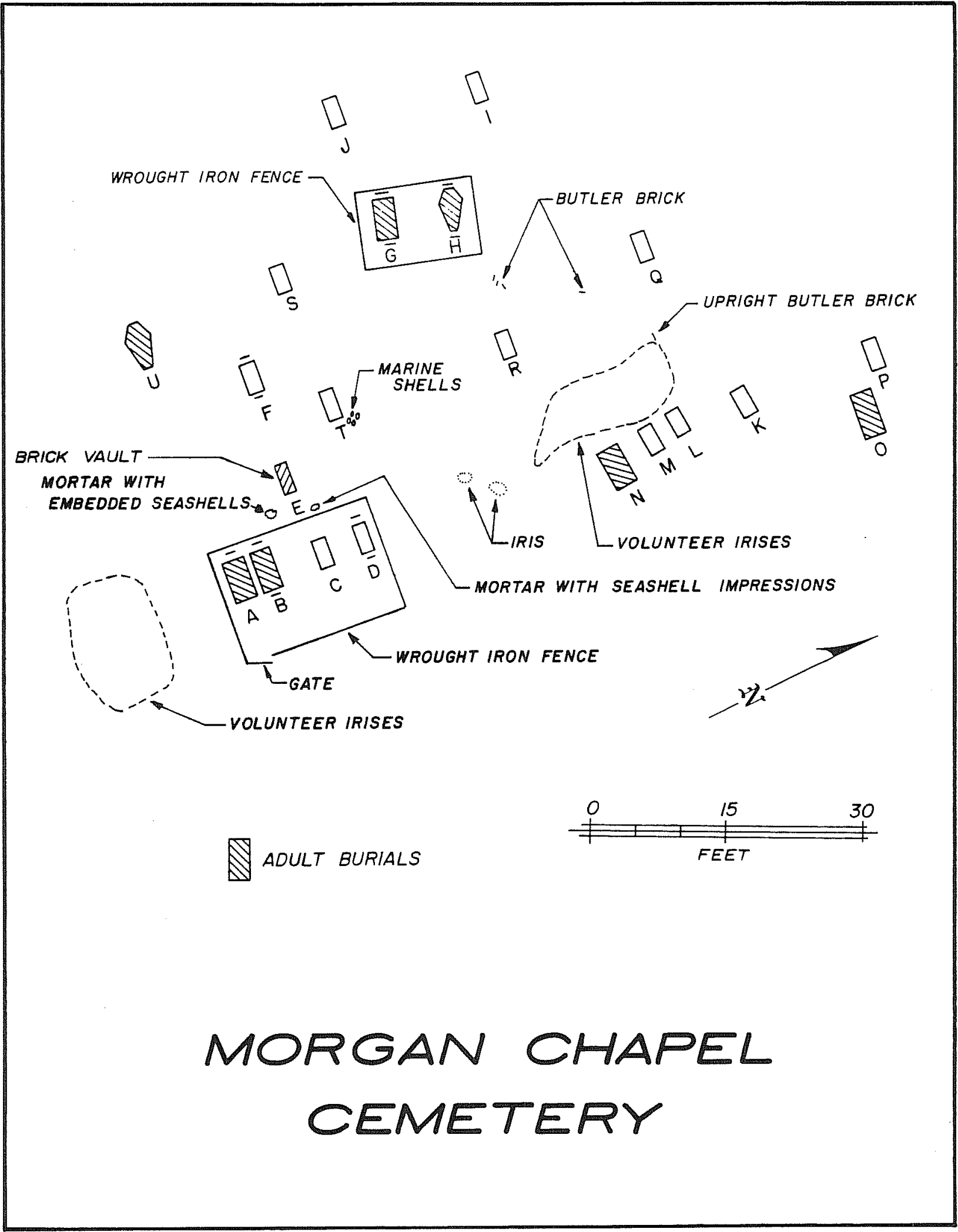

Figure 4. Map of Morgan Chapel Cemetery (41 BP 200) Showing Grave Locations, Coffin Forms, Age Groups, and Features. 
A concentration of rough sandstone blocks and parts of a concrete foundation were located a short distance north-northeast of the cemetery, and may mark the former location of Morgan Chape1. A brick cistern with sandy concrete mortar, which was located on the north-central side of the property, appears to date after 1930, and would be associated with the 1 ater occupation of the site.

\section{ARCHAEOLOGICAL BACKGROUND}

Archaeological investigations of historic cemeteries in Texas are quite 1 imited. Only a few Spanish colonial aboriginal cemeteries, which were associated with missions, have been investigated. The burials at such sites are generally intermixed due to the practice of burying individuals within a certain 1 imited area which was consecrated, such as beneath a church floor or in a churchyard. Schuetz (1968:202-215, Figs. 23, 25, 26, P1ate 10; 1969:116-124) has reported the excavation of at 1east 63 mission Indian burials from Mission San Juan Capistrano in San Antonio, Texas, which date ca. 1763-1785. Most of the burials were young and middle-aged adults, though there were a few elderly individuals and approximately 10 infants. Variability in the ethnic types present at the mission, and also a high occurrence of diseases, were indicated in the skeletal material. Individuals were usually buried in an extended, supine position facing east, though a few faced west, and the forearms were folded across the chest. Some individuals were clothed when buried, and a few had religious medals, rosaries, crosses, or crucifixes. They were placed without a coffin beneath the church floor.

Additional excavations at Mission San Juan Capistrano, reported by Schuetz (1974:24-35, 49, Figs. 10-14), uncovered 92 individuals of which 51 (55.4\%) were adults, and $41(44.6 \%)$ were children. These burials appear to date from 1793 to 1862. A11 burials (except one with a hexagonal wooden coffin) had rectangular wooden coffins constructed with square cut nails. At least two coffins, which contained infants, had painted exteriors. A11 but one burial were $\mathrm{placed}$ in an extended, supine position facing south toward the church altar. Some individuals were clothed when buried and had grave goods such as Indian potsherds, flint tools, she11, and animal bone; none had any religious paraphenalia. Two burials included metal points which may have been the cause of death for those individuals. Skeletal analysis indicates a racial admixture for the group, with 10 (10.9\%) individuals identified as being definitely Indians, five (5.4\%) as possible Indians, one (1.1\%) as a definite Caucasian, and the remainder (82.6\%) were of uncertain race.

Gilmore (1969:60-61, 76-81, Figs. 5, 6) reports the excavation of 11 burials, which included two (18.2\%) infants, from Mission San Juan Xavier in Milam County, Texas. This site dates from 1746 to 1755. At 1east one of the individuals had been reburied. Most of the burials were extended and supine. With the exception of two infants, all the individuals had one or both arms semiflexed, and four (36.4\%) had their legs crossed at the ank les or knees. Eight $(72.7 \%)$ of the burials were oriented north to south facing north, and three (27.3\%) were oriented east to west facing west. Grave goods were found with four (36.4\%) individuals, but no religious items were included, and some individuals may have been clothed when buried. Grave pits were small, appearing to have been dug barely large enough to contain the body. No 
evidence of coffins was found. The burials may have been p 1 aced beneath a church or in a churchyard, though this is not certain.

There are also reports of isolated historic Plains Indian burials in Texas (Moorman and Jelks 1953; Newcomb 1958; Suhm 1962; Ray and Jelks 1964; Parsons 1967; Bennett 1968; Hester 1968; Word and Fox 1975; Taylor 1975a; LeV ine and Freeman 1982:314-316, Tab 1e 6). These individual burials were general1y placed beneath an overhang or in a small shelter, with numerous European and aboriginally made grave goods such as horse trappings, beaded clothing, and weapons, and also animal bones.

Carter and Ragsda1e (1976:30-52, 98, citing Morris 1975 and Coates Field Service Files 1974-1975) mention the relocation of 150 graves from the middle 1800s, located in several rural family cemeteries of a small German community, Biegel's Settlement, in Fayette County, Texas. These cemeteries included the Biege1-December Cemetery (4I FY 94) and the Kroll family child grave (4l FY 95). It does not appear, however, that archaeologists were involved in the cemetery relocation activities.

Numerous Mexican soldiers were excavated from a mass grave (4I CF 3 ) at the Resaca de la Palma battlefield by Collins, Hester, and E1 1zey (n.d.; Hester 1978:71, Fig. 5). The burials date to May 9, 1846, during the Mexican War.

The relocation of 22 graves with 23 individuals (one grave contained a young adult female and an infant) from the Laredo Cemetery (41 WB 22) in Webb County, Texas, was reported by McReynolds (1981a, 1981b). These burials date to the late 1800s and early 1900s, and were possibly both Hispanic and Anglo-American, and at least some of the burials were affiliated with the Catholic Church. Six of the 23 burials removed were damaged or destroyed by construction activities; 13 additional graves were detected but were not exhumed.

Fox (1984) reported the relocation of 34 graves in five historic rural cemeteries (4I LK 73, 41 MC 4, 41 MC 6, 41 MC 18, and 41 MC 66) at Choke Canyon Reservoir in Live Oak and MCMulien Counties. Texas. The burials date from 1860 to 1913, with most from 1858 to 1880.

Morgan Chapel Cemetery was first documented by photographs and mapping, by Roemer in 1980 (Kel1y and Roemer 1981:14-18), during a survey of the area by the CAR-UTSA for CPS. Brown (1986) did more detailed documentation of the site during a later survey for CPS by the CAR-UTSA. This later investigation included preparing a plane table map, photographing the headstones and noting detai1s, searching for signs of unmarked graves, and al so monitoring the clearing of brush and debris that had accumulated at the site. 
FIELD WORK

\section{METHODOLOGY}

Since Morgan Chapel Cemetery was previously recorded by the CAR-UTSA archaeologists (Ke11y and Roemer 1981:14-18; Brown 1986), the authors were $a b l e$ to utilize that research and the existing base map of the cemetery during the grave removals. A transit operated by the archaeologists was used to map exposed features during the first part of the project. A professional surveyor. who used a theodolite, was employed to map the site and features during the later part of the project. Each burial was assigned a consecutive alphabetic designation, continuing the grave designation system used by Kelly and Roemer (1981), and Brown (1986).

On August 3, a work crew cleared the brush from the cemetery area in preparation for the excavations. During the cemetery removal, which began on August 6, certain personnel were present whenever excavations were being conducted. A representative from CPS, usual1y Cindy Sou 1e; a representative from the Newby Funera 1 Home, Inc., J. E. McIntire; and the CAR-UTSA archaeologists were present throughout the project. The legal representative for the Methodist Church, James Odiorne, was also present during the first part of the project, and was then replaced by various Methodist ministers from the area. The CPS representatives, the morticians, the Methodist Church representatives, and the construction personnel al 1 cooperated with the archaeologists and provided numerous helpful suggestions during the cemetery remova1. Descendants of the deceased were permitted to view the excavations of the burials, and most were quite interested in the procedure. These relatives were able to provide some information about the identity, age, occupation, and also sometimes maladies of certain individuals buried at the cemetery. They, in addition to various other local informants--some of whom were demonstrating against the cemetery removal, also told us what they could remember about the count and 1ocation of burials at Morgan Chapel Cemetery (see Austin American-Statesman 1984; Elgin Courier 1984a, 1984c).

The excavation procedure for the marked burials consisted of the removal of upper grave fill from marked graves with a Bobcat backend loader that had a scoop. Once wood from a vau1t, coffin box, or coffin was encountered with the scoop, a shovel was then used to remove the remaining grave fill. In many of the burials a deposit of 1 ight gray sand was above and around the vault and coffin; whenever this sandy deposit was encountered, machine excavations were halted, and hand excavations began. During the later part of the project, the machine operator also removed the soil surrounding the burial, leaving it isolated on a pedestal, a technique that made excavation much easier than when the archaeologist worked in a narrow trench. The burials were then careful1y exposed (Fig. 2,b) with tools such as trowels, smal1 picks, and brushes, and were recorded. For each burial a burial form was completed, photographs were taken, and elevation readings were taken for the top of the burial (the top of the vault, the coffin box, or the coffin), and the bottom of the grave as marked by the bottom of the coffin. Samples were taken of gray sandy soil associated with some of the burials, wood from the vault planking, coffin box, coffin, and also fabric. After this procedure, the burials were carefully removed, and the remains were placed on cotton padding for protection during analysis. After the remains had been 
adequately examined, they were then put into individual, modern coffins. Personal field journals were kept daily by the two senior archaeologists. A maximum time of one work day was spent on each burial, with the time varying from roughly three to eight hours. This amount of time allowed to excavate and record historic burials appears to be quite generous in comparison to that allowed archaeologists during other similar projects (see Ferguson 1983:57; Fox 1984:9, 12, 15, 24, 32,34). Graves detected at the end of the work day were located on the site map, marked with a flagged pole, and were then refilied. To avoid any possible accidents which might result from curiosity seekers attempting to examine the site at night, none of the grave pits were left open overnight.

Originally the work was planned to detect unmarked graves by scraping away the sandy topsoil with a machine blade to expose the outline of the remaining grave pits. This procedure was successfu1 1y used by Phelps (1979:15-17), B 1 ake 1y and Beck (1982:182-184), and Fox (1984) to detect unmarked graves. After the first grave was excavated, however, it was apparent that the nature of the clay subsoil was such that outlines of the graves were obscured; this made the detection of the unmarked grave pits very difficult.

The site was covered with an 8- to 12-inch-thick deposit of sandy loam. The subsoil was a compact red brown sandy clay with fine yel low and orange mottling. With increased depth the color of the clay changed from red brown to gold, with a few 1 enses of black and 1 ight gray clay also occurring. Natural pockets of sand were noted in the lower layers of clay. The clay at the site is a paleustalf which appears to have a high shrink-swell potential, and may have resulted in the obliteration of the grave pit outlines (United States Department of Agriculture 1979:3, Tab1e 6).

An abrasive, 1 ight gray sandy material was observed around the vault planking and coffins in some of the graves. It was not evident whether this material was naturaliy occurring sand that had been shoveled into or seeped into the grave, or if it was 1 ime that was deliberately added to the burial to prevent contamination. Samples of this material were taken from some of the burials and analyzed. The calcium counts of the material reported in the soils test are presented later in this report.

Since the bones from the graves were poorly preserved and quite fragile, perhaps at least partly due to the acidic nature of the cemetery soils, they usually were examined by the physical anthropologist while in situ. Although bone was present in al1 the graves, it was often crushed, especially in infant and child burials. Once the skeletal material was retrieved, it was further analyzed by the physical anthropologist. The morticians, who were quite cooperative, were in charge of the skeletal remains and kept them in the funeral home after work hours; the physical anthropologist and archaeologists were given access to the remains, however, if further analysis was necessary. The grave goods and coffin hardware were also curated by the morticians, and were available for additional examination if necessary. Samples of the vault planking and/or coffin wood were collected from 18 of the 21 graves (though al1 the graves did have wooden coffins) by the archaeologists for 1 ater analysis (see Holloway. Appendix B), but the personal effects and coffin hardware were returned to the morticians to be placed in a new coffin with the respective individual's remains. The burials from Morgan 
Chapel Cemetery were relocated in either the nearby McDade Cemetery or the Ridgeway Cemetery.

After August 8, a 11 the marked graves $(A-H)$ were exhumed, and the decision was made at the suggestion of the Texas Historical Commission representative to extend trenches across areas of the site where graves were reported or suspected, using mechanical trenchers. Certain areas were suspect because of the presence of volunteer irises that may have been $p 1$ anted on or near graves, and loose brick that may have formerly been set around the edges of graves; for instance, Graves $B, C, D$, and $F$ had bricks outlining them (Kelly and Roemer 1981:15; Brown 1986). It was original1y thought that grave pits could be detected in the trench profiles. A smaller trencher, a Ditch Witch, was initially used, which cut a trench roughly 12 inches wide and 3 feet deep. The larger trencher, a Vermeer T-600D, was then used to cut the majority of the trenches at the site; it cut a trench approximately 14 inches wide and 5 feet deep, which provided a more accessible profile for the archaeologists to examine and to excavate more rapidly than the smal1er trencher. More than 1700-1 inear feet of trenches were dug within less than a two-acre area of the cemetery property, with an archaeologist following the trencher, watching for signs of coffin wood or coffin hardware in the backdirt, and walking in each trench to examine the sides of the trench for signs of grave pits. It was found that the trencher excavated in a manner that resulted in a clean cut on one side of each trench, while the opposite side was covered with fine dust that masked the profile; as a result, on $1 y$ one side of the trench could be examined for grave pits. When a suspected grave pit was located, the archaeologist put a wooden stake with flagging tape into the ground by the location, or placed a pole with flagging tape into the trench by the possible grave pit, to serve as a reference point. $A$ backhoe was then used to excavate the marked area to determine if it actual1y was a grave. The extent of the trenching was recorded on the site map.

Three unmarked graves ( $I-K)$ were located by trenching, and two of these (Graves $J$ and $K$ ) were disturbed by the trencher. Another grave $(0)$ was 1 ater found to have been disturbed by trenching, but was not spotted during this phase of the project. Numerous oaks were in the cemetery, and the root action of these trees and of previous trees created areas of disturbance with a mixture of 1 ight tan sand and clay that occasionally resembled grave pits, and added to the difficulty of detecting graves. Several suspected grave pits, which were excavated with a backhoe, were found to be areas that had been subjected to root action.

CPS discussed the results of the excavations with the THC representatives at this point, to determine what methods might be employed to ensure the satisfaction of the THC personnel (and also the 1 ocal residents) that a 11 burials, marked and unmarked, were located and removed from the cemetery. It was the wish of the CPS representatives to take whatever steps were necessary to locate al1 the Morgan Chapel Cemetery burials during this phase. It was the opinion of the THC that some grave pits, especially those for infant burials which are much shorter might be undetected using the trencher; the distance between parallel trenches was approximately 3 to 3.5 feet, although it was wider in a few areas with dense tree growth where the trencher went around trees. Therefore, there was a chance that burials would be missed, extensive as the trenching might be. The THC representatives expressed the 
opinion that the only method which would ensure that a 11 the Morgan Chapel Cemetery burials were located and removed, would be to excavate the entire cemetery. This procedure, however, was considered to be more extensive than was necessary, and was not recommended by the THC representatives.

The decision was then made by CPS on August 14, to excavate al1 of the 3.055 acres of the Methodist Church property, which extended well beyond the cemetery limits, to make certain that al1 burials were located and removed. This would include a total of approximately 30,000 cubic yards of dirt. At this time it was decided that the excavations would extend to a depth of six feet, since the general belief is that most graves are dug to this depth. Contrary to this belief, however, the depth of most graves is 5.5 feet or less--at least in Texas, according to J. E. McIntire (1984), a mortician of long standing.

The heavy machinery used for the large-scale excavations included the foll lowing: one John Deere 410 backhoe, one Caterpillar D6 with rippers and tilt blade, one Caterpillar D7 with rippers and tilt blade, two Caterpil1ar 120 graders, three Caterpil1ar 613 paddle-wheel scrapers, and one Case 4690 tractor with an 18-yard bucket. The machine operators stated that this equipment was capable of stripping the soil in three- to four-inch-thick layers. With this assurance the archaeologists were of the opinion that this technique could be utilized without substantial risk of damaging the remaining burials; evidence of the vault planking and coffin wood, which was more than three to four inches above the burials, could be spotted before the burials were damaged. Additional1y, with the continued monitoring of the excavations by the archaeologists, none of the burials should go undetected.

Arrangements were made to have a registered surveyor rep 1 ace the archaeologists to map the property boundaries and features, and to monitor the excavation depths. The surveyor recorded the depths of Graves $P-U$, while the depths of Graves $A-R$ were previously recorded by members of the archaeological crew. The operation of a transit by the archaeologists had been made more difficult by the expansion of the project area to include the entire church property, and became even more difficult once the blading operations began and the original datum points and reference points were removed. The presence of a registered surveyor, then, was welcomed at the site by the archaeologists. When differences in the elevation of burials were encountered during the writing of this report, the elevation readings of the surveyor were used in preference to those made by the archaeologists since the surveyor had a more secure datum point, a more sophisticated instrument, and more experience and training in mapping than did the archaeologists. The surveyor noted (Soule 1984) that his readings for the grave elevations were consistently lower, or deeper, than those recorded by the archaeologists. He suggested that the differences in readings might be caused by the different elevations of the surveying stations, with the archaeologists having a higher station than the surveyor. The actual depth below ground surface could not be measured during the 1 ater part of the project since the original ground surface had been removed; general elevations taken of the ground surface at the site were used to estimate the depths of later burials below the ground surface. 
The later stage of the project began with the removal of all the vegetative ground cover at the site, including numerous oak trees. The trees were removed using bu 11 dozers (see The Bastrop Advertiser \& County News 1984b; Elgin Courier 1984d). Since this activity was considered to not be subsurface excavation, and unlikely to affect the burials, the archaeologists gave their consent for the construction crew to continue clearing ground cover during the evening after the regular work hours with no archaeologists present, in order to expedite the project. This decision, however, resulted in the county judge being contacted that night by $10 \mathrm{cal}$ people who reported that the cemetery was being dug up without the presence of any archaeologists or morticians. The county judge and county sheriff appeared at the site the next morning to investigate the matter. After some discussion with the archaeologists, they were assured that no excavations had occurred there without proper supervision. We in turn decided not to approve any such activities at the site without our presence to avoid any future incidents of this sort.

With the approval of the archaeologists, the top 2.5 to 3 feet of sandy 10 am and underlying clay were rapidly removed with heavy machinery in levels measuring approximately one foot thick. This action, which sped up the excavation process, was approved since no vault planking, coffin boxes, or coffins had been located above 2 feet 9 inches. Below the 2.5 to 3 feet leve1, a blade was used to peel away the basal clay in three to four inch 1ayers. Two archaeologists followed the machinery, watching the exposed ground surface for evidence of vault or coffin wood while riding Honda 200M three-wheelers that were provided by the contractors for this purpose. The three-wheelers proved to be effective for transporting the archaeologists across the site while permitting them to view the ground surface at close range; an advantage of using these vehicles was that they provided a means for the archaeologists to keep pace with, and also to move rapidly out of the way of, the heavy machinery.

Ten graves $(L-U)$ were located during the machinery b 1 ading. It should be noted that none of these 1 ater burials were damaged by the blading. The location of wood from the vault or coffin, or a concentration of 1 ight gray sand above the coffin provided a reliable means of detecting the burial before it could be harmed by machine excavations. A few pieces of petrified wood were exposed during the blading of the sandy topsoil. A local resident suggested that the petrified wood may have served as markers for some of the graves (Weaver 1984). The former placement of the petrified wood could not be determined, however, to check if this suggestion was correct.

The 1 ast burials were removed on August 21. The archaeologists continued to monitor excavations of the property through August 28, when a depth of six feet below ground surface was achieved for a 11 of the property. Backfilling operations then began, which the archaeologists did not consider necessary to monitor. This decision was questioned by certain local residents and county officials of the area, who were of the opinion that removal of earth from the backfill pile to the former cemetery area should be considered excavation, and should accordingly be monitored by archaeologists, morticians, and church representatives. Additional1y, a relative of certain deceased individuals reportedly buried in Morgan Chapel Cemetery, remained unconvinced that his relatives were recovered as no burials were found as he recalled their 
location and arrangement (see E1gin Courier 1984e; The Bastrop Advertiser \& County News 1984b). These matters were resolved to the extent that the refilling operations were permitted to resume and were completed without monitoring.

\section{THE BURIALS}

Brief descriptions of the eight marked graves $(A-H)$ in Morgan Chapel Cemetery were previously presented in Kelly and Roemer (1981). Additional detajls of these burials are included in Brown (1983, 1986). The grave 1ocations and features in the cemetery are shown in Figure 4. Selected burial data are provided in Tables 1-3, and a glossary defining certain terms is provided at the end of the report. The burial descriptions are presented in alphabetical order rather than necessarily in the order in which they were exhumed.

Preservation of the skeletal remains for the 21 burials ranged from moderately poor to extremely poor; the state of preservation of the bone was probably affected by the acidic nature of the clay subsoil at the site. Bone was present in all the burials with the exception of Graves $\mathrm{J}$ and $\mathrm{K}$, which were badly disturbed by trenching. An analysis of the skeletal remains is presented separately by Massey (Appendix A).

The coffin, vault planking, and coffin box, al 1 of which were wooden, were fairly wel1 preserved, although the weight of the grave fill crushed them. An analysis of the coffin, coffin box, and vault samples is presented by Hol loway (Appendix B).

Much of the coffin hardware, which was made of iron, white metal, and cupreous metal, was badly corroded and brittle. All the adult coffins had six handles, while the infant and child coffins had four handles.

Fragments of fabric were preserved in some burials. The fabric samples were examined by Anne Fox using a binocular microscope with various magnification (see the glossary for explanation of the terms used). The higher the count of threads to the inch, the finer the weave of the resulting fabric. The reader should note that the present colors of these fabrics are probably not the same as the original fabric colors.

The age and sex of the individuals described below were obtained from gravestone inscriptions, the coffin and vault planking size, burial goods, and observations made by Massey (Appendix A).

\section{Grave A}

Grave A was identified from the headstone as the burial of William F. Cruse, a Civil War Confererate veteran who died in 1924 at the age of 81 years. Relatives of Cruse stated that he was a part-time carpenter, and he may have constructed some of the coffins at this cemetery. Brown (1986) reports that Samuel Cruse, the father of William F. Cruse, was also a carpenter. Further information concerning William Cruse is provided in Brown (ibid.). A gabled marble headstone with the design of a gothic cross with a circular wreath 
TABLE 1. LISTING OF THE MORGAN CHAPEL CEMETERY BURIALS BY AGE, SEX, BIRTH, AND DEATH DATES, AND ASSOCIATED BURIAL GOODS

\begin{tabular}{|c|c|c|c|c|}
\hline Grave & Age & Sex & $\begin{array}{l}\text { Birth and } \\
\text { Death Dates }\end{array}$ & Buriat Goods \\
\hline A & 81 years & Male & $1843-1924$ & - \\
\hline$B$ & 65.5 years & Female & $1848-1914$ & hair comb \\
\hline C & $1-2$ years & $?$ & $?$ & - \\
\hline D & Infant & Female & 1897 & button \\
\hline$E$ & Subadult & ? & $?$ & - \\
\hline $\mathrm{F}$ & 11-12 months & Female & $1891-1892$ & - \\
\hline G & 71 years & Female & $1833-1904$ & - \\
\hline $\mathrm{H}$ & 79 years & Female & $1812-1891$ & - \\
\hline I & $7-11$ months & $?$ & ? & - \\
\hline J & Infant & $?$ & ? & - \\
\hline $\mathrm{K}$ & Infant & $?$ & $?$ & - \\
\hline $\mathrm{L}$ & 4-8 months & $?$ & ? & safety pin \\
\hline $\bar{M}$ & $1.5-2.5$ years & $?$ & $?$ & - \\
\hline$N^{*}$ & Adult & Male(?) & $?$ & - \\
\hline 0 & Adu $1 t$ & $?$ & $?$ & - \\
\hline$P$ & 6 months or less & $?$ & $?$ & - \\
\hline 0 & $12-15$ years & $?$ & ? & - \\
\hline $\mathrm{R}$ & Infant & $?$ & $?$ & beads, buttons \\
\hline$S$ & Infant & $?$ & $?$ & safety pin \\
\hline $\mathrm{T}$ & Infant & $?$ & $?$ & - \\
\hline$U$ & Adu $1 t$ & Female(?) & $?$ & $\begin{array}{l}\text { reddish brown } \\
\text { cuffs of a } \\
\text { plain weave } \\
\text { cotton fabric } \\
\text { with clips, } \\
\text { button, garment } \\
\text { hook }\end{array}$ \\
\hline
\end{tabular}

\footnotetext{
* = This individual was buried face down.

$?=$ unknown
} 
TABLE 2. LISTING OF THE MORGAN CHAPEL CEMETERY BURIALS BY PRESENCE OF GRAY SANDY SOIL, COFFIN BOX OR VAULT PLANKING, COFFIN SHAPE, PAINTED COFFIN, LINED COFFIN, AND GLASS FRONT OR SEALER

\begin{tabular}{|c|c|c|c|c|c|c|}
\hline Grave & $\begin{array}{l}\text { Gray } \\
\text { Sand }\end{array}$ & $\begin{array}{l}\text { Box or } \\
\text { Vault }\end{array}$ & $\begin{array}{l}\text { Coffin } \\
\text { Shape }\end{array}$ & $\begin{array}{l}\text { Painted } \\
\text { Coffin }\end{array}$ & $\begin{array}{l}\text { Lined } \\
\text { Coff in }\end{array}$ & $\begin{array}{l}\text { Gl ass } \\
\text { Front }\end{array}$ \\
\hline A & - & Vault & $R$ & - & - & - \\
\hline B & $x$ & Box & $\mathrm{R}$ & - & ** & - \\
\hline C & $x$ & Box & $\mathrm{RC}$ & - & ** & $x$ \\
\hline D & $x$ & Vault & $\mathrm{R}$ & - & - & - \\
\hline $\mathrm{E}$ & $x$ & Vault & $\mathrm{R}$ & $x$ & - & - \\
\hline $\mathrm{F}$ & $?$ & Vautt & $\mathrm{R}$ & $x$ & $x$ & $x$ \\
\hline G & $?$ & Vault & $\mathrm{RC}$ & - & ** & $x$ \\
\hline$H$ & - & Vault & $\mathrm{H}$ & - & - & $x$ \\
\hline I & $x$ & - & $\mathrm{R}$ & $x$ & $x$ & $x$ \\
\hline $\mathrm{J}$ & $x$ & Vault & $\mathrm{R}$ & $x$ & - & - \\
\hline K & ? & Vault & $\mathrm{R}$ & - & - & - \\
\hline L & $?$ & Vautt & $\mathrm{R}$ & - & - & $x$ \\
\hline M & $?$ & Vau $7 t$ & $\mathrm{R}$ & - & - & $x$ \\
\hline $\mathrm{N}$ & $?$ & Box & $\mathrm{R}$ & - & $?$ & - \\
\hline 0 & $x$ & Vault & $\mathrm{R}$ & - & $?$ & - \\
\hline$P$ & $\mathrm{x}$ & Vault & $\mathrm{R}$ & - & $x$ & - \\
\hline$Q$ & $x$ & Vault & $\mathrm{R}$ & - & $x$ & - \\
\hline $\mathrm{R}$ & $\mathrm{x}$ & Vau $7 t$ & $\mathrm{R}$ & $x$ & - & $x$ \\
\hline S & $x$ & - & $\mathrm{R}$ & - & $?$ & - \\
\hline $\mathrm{T}$ & $x$ & Vault & $\mathrm{R}$ & $x$ & $?$ & - \\
\hline u & $x$ & Box and Vault & $H$ & $x^{*}$ & $?$ & - \\
\hline
\end{tabular}

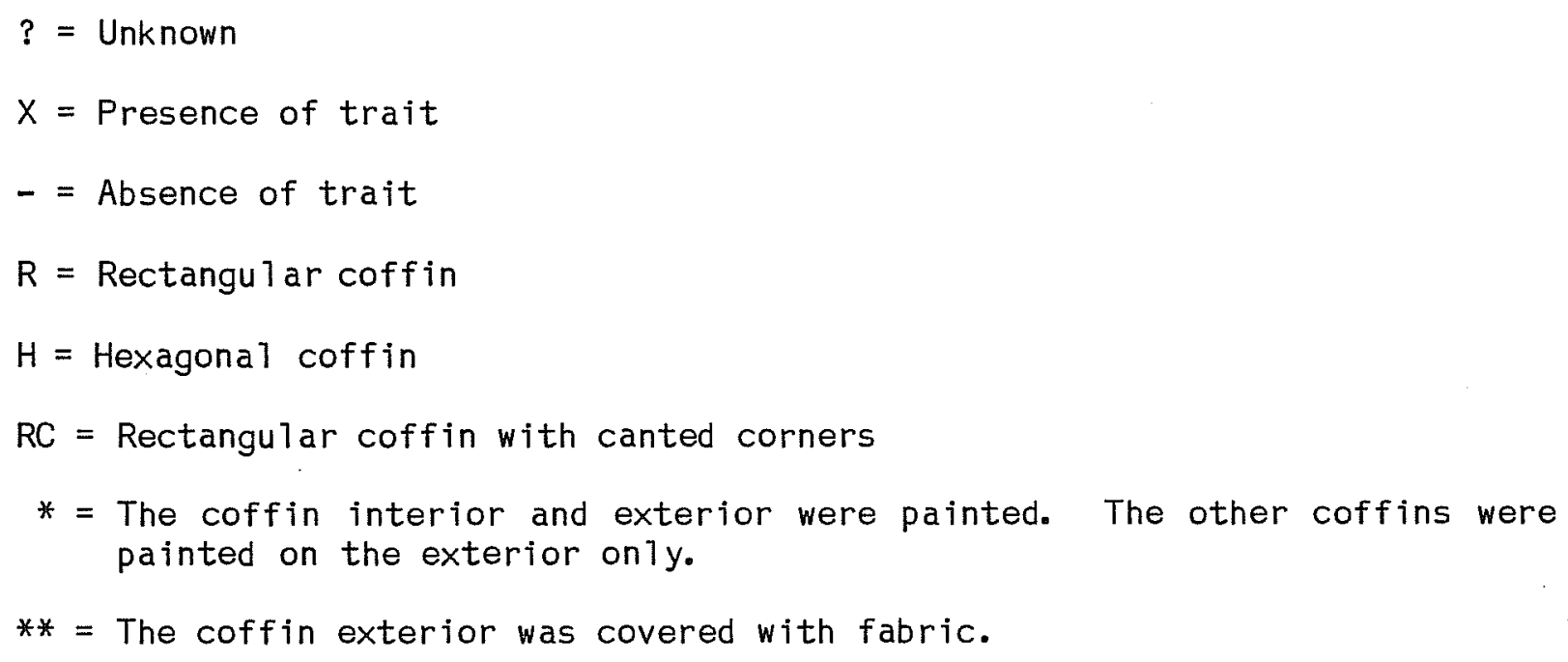


TABLE 3. LISTING OF THE MORGAN CHAPEL CEMETERY BURIALS BY COFFIN MEASUREMENTS; THE DEPTH (BELOW GROUND SURFACE) OF THE VAULT, COFFIN BOX OR COFFIN TOP; AND THE DEPTH (BELOW GROUND SURFACE) OF THE COFFIN BOTTOM

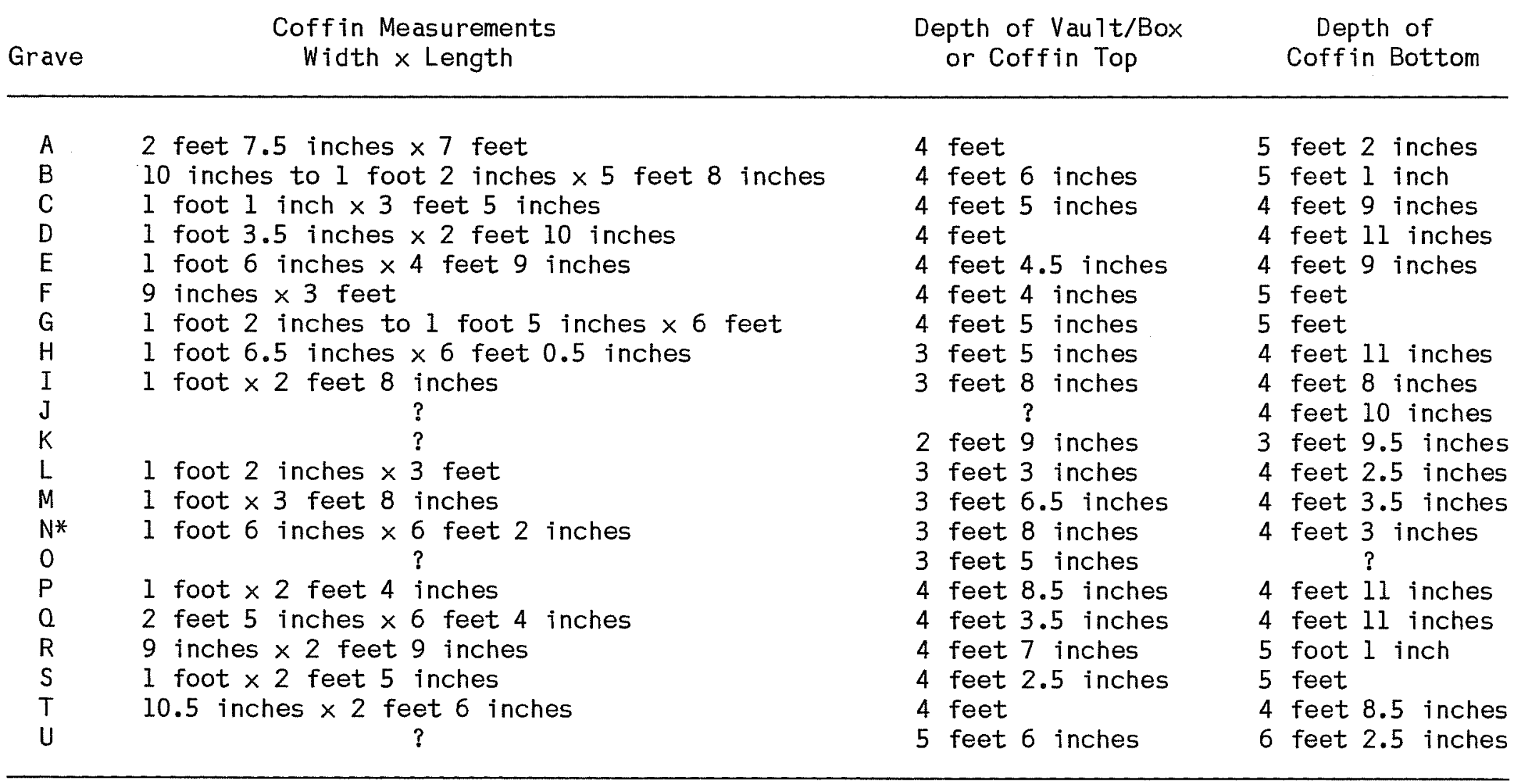

* = This individual was buried face down.

$?=$ Unknown

Measurements for the top and bottom of coffins are the depths below modern ground surface. 
element within a circle marked the grave. The headstone base was made of brick. The inscription on the headstone read "WILLIAM F. CRUSE, CO. C, WALLER'S REGT., TEXAS CAV., C.S.A." Loose brick was a1so present at the foot of the grave. During the grave pit excavations, a metal temporary grave marker was unearthed which had the inscription, "died April 7 - 81 yrs 4 mo -

" (1ast part obliterated). (Note: this date differs slightly from that of Apri1 5, 1924, in the Mi11er Funeral Home Records [1911-1950].) Irises grew on the grave.

The grave had a dug vau $1 t$. The rectangular, pine coffin was the largest found in the cemetery. Hardware for the coffin included six two-piece white metal handles that once had wooden grips (Fig. 5,a). Sma11, flat pieces of iron, which were probably used to construct the coffin, were also found. The skeletal remains were disturbed by smal1 burrowing animals, and bone preservation was poor. No burial goods were found.

\section{Grave B}

Grave $B$ contained the remains of Ann M. Cruse, the wife of Wi11iam F. Cruse (Grave A); she was buried north of her husband's grave. She died in January 1914, at the age of 65.5 years. The sandstone headstone, a squared column, was placed over the grave pit, indicating it was not added until the grave out 1 ine was obscured. The headstone inscription read "ANN M. CRUSE, BORN JULY 4, 1848, DIED JAN. 10, 1914, SHE IS AT REST IN HEAVEN." The upper face of the headstone shows a flying dove carrying an olive branch, and an open gates of heaven motif. A floral design extends around the headstone. The headstone base is also inscribed "CRUSE." The grave had a sandstone footstone with the inscription "A. M. C." Two rows of machine pressed brick, one with angled bricks and the other with flat laid bricks, outlined the grave. Irises grew across the grave.

Enclosing the coffin was a pine coffin box which was a minimum of 22 inches wide, and was roughly the same length of the coffin. The rectangular coffin was narrow and tapered toward the feet, and the exterior was covered with dark brown fabric. The fabric covering the coffin exterior was nonwoven and consisted of paral1el rows of single ply wool fibers with a z-twist. The method of bonding the fiber was not apparent; no warp was present, and there were 24 threads to the inch. The coffin hardware consisted of four-part white metal decorative hand les that once had wooden grips (Fig. 5,b). One handle bore the inscription "patd - July 10 - 1908, S \& Co, 1874." White metal rosette studs $(F i g .5, c)$, a white metal plaque inscribed "IN GOD'S LOVE," and decorative iron thumbscrews were attached to the coffin exterior; one thumbscrew was inscribed "Ptd June 20, 1--6." A composition hair comb (Fig. 5,d) was found by the sku11, and the individual's arms were folded across the chest.

\section{Grave C}

Grave C was out 1 ined with a single row of angled, machine pressed bricks. The burial was of a child approximately one to two years of age. This individual was in the Cruse family plot, and may have had the surname of 

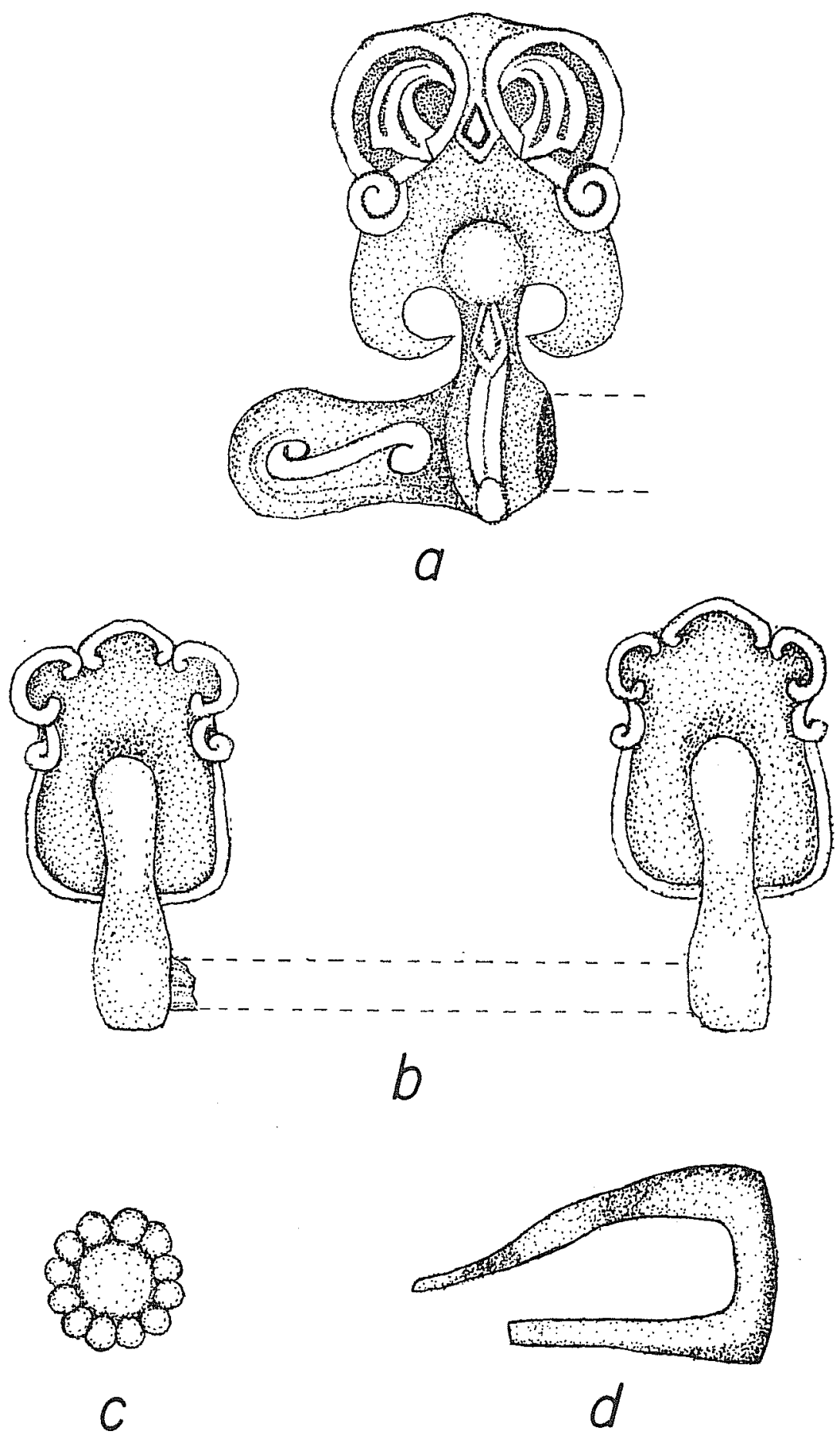

b

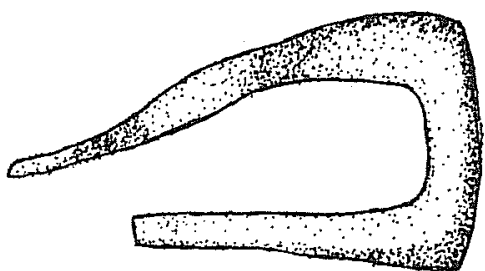

O

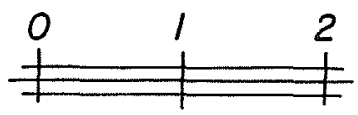

INCHES

Figure 5. Coffin Hardware from Graves A and B. a, the left part of a twopiece white metal handle with a wooden grip from Grave $A$; the grip is indicated by dashed 1 ines; $b$, the right and left parts of a four-piece white metal handle with a wooden grip, from Grave B; the grip is indicated by dashed 1 ines; $c$, a white metal rosette stud from Grave B; d, a composition haircomb from the cranial region of Grave $B$. 
Baker or Butler. According to a relative, Leroy Creel (1984) of McDade, the child may have been related to Ann M. Cruse (Grave B). Brown (1986) observed a fallen marble column at the foot of the grave, which was no longer in place when the cemetery relocation began.

The rectangular hardwood coffin was enclosed in a thin, wooden coffin box which was probably made of pine. The coffin had canted corners and a wooden 1id, and was covered with light tan fabric. The fabric covering the coffin exterior was cotton woven in a diamond weave, and bore the imprint of the metal 1 aque that was on top of the coffin. The warp was z-twisted with 80 threads to the inch, while the weft was z-twisted with 56 threads to the inch. The coffin also had a rectangular glass front with canted corners, which measured 5.75 inches by 20-21 inches, and was 0.09 inches thick. The coffin hardware included white metal handles (Fig. 6,a), white metal decorative studs, and a cast white metal plaque with the inscription "OUR DARLING." The infant's hands were folded across the abdomen. No burial goods were found.

\section{Grave D}

Grave D contained an infant, possibly stillborn, daughter of Joshaway and Jennie Browning, and granddaughter of William F. and Ann M. Cruse. This individual was buried in the Cruse family plot. The grave was marked by a sandstone headstone with the inscription "INFANT DAU. OF JOSHAWAY \& JENNIE BROWNING, BORN AUG. 27, 1897." The headstone had a scrol1 design, and was set into a concrete base. A plain sandstone footstone, which was dislocated, was by the grave. A double border of machine pressed bricks, with one row angled and the other $f l a t$, out 7 ined the grave.

The grave had a dug vault. Either the vault planking or the coffin were made of pine. The coffin was rectangular and had white metal handles, white metal and iron thumbscrews, hollow half-hemispherical studs, and a cupreous plaque inscribed "OUR DARLING." Extra long iron nails were used to construct the coffin. A smal1, four-hole, white button was associated with this burial.

\section{Grave E}

Judging from the size of the coffin and the fragility of the skeletal material, the burial in Grave $E$ was a young subaduTt. An unmarked, handmade brick false crypt with a sandstone foundation was above the burial. The top of the crypt, which was at least seven courses tal1, was capped with concrete into which Chione cancellata she115, the cross-barred venus, from the Texas coast were embedded. The crypt measured 5 feet 0.5 inches by 2 feet 11.25 inches, and was approximately 18.5 inches tal1. No name or dates were found associated with this burial. ETa Casey of Elgin, however, remembered the individual as being a child of the Cassel or Kessel family (Casey 1980). The brick crypt was filled with sand.

The grave pit was filled with clay similar to that in the other graves. The grave had a dug vault with vault planking that measured 2 feet 6 inches by 5 feet 1 inch. The coffin was rectangular, and the exterior was painted with 


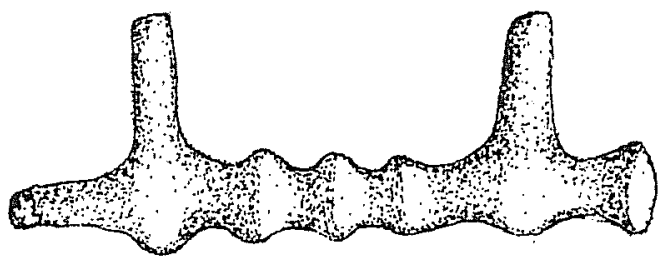

a

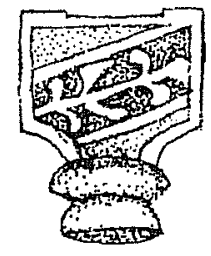

$b$

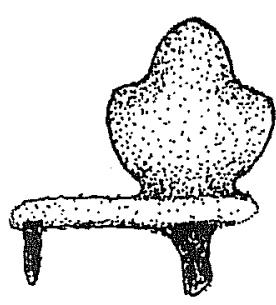

d

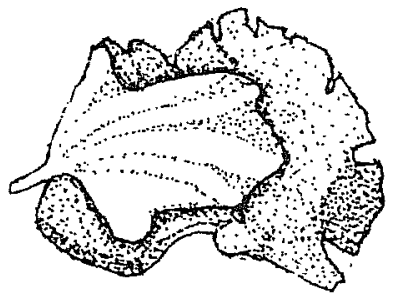

C

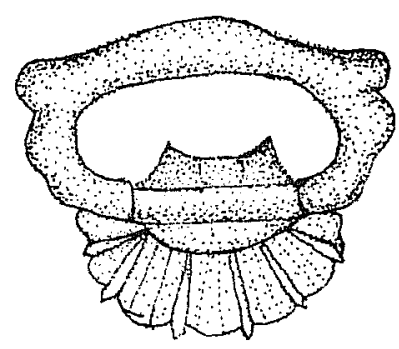

e

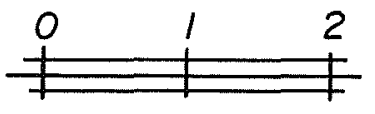

INCHES

Figure 6. Coffin Hardware from Graves C, E, G, H, and K. a, a white metal handle from Grave $C$; $b$, a white metal decorative thumbscrew from Grave $E_{\text {; }} c$, an iron, leaf-shaped stud from Grave G; d, a trilobed iron thumbscrew from Grave $H$; e, a white metal handle from Grave K. 
white gesso or paint. White metal handles, white metal and iron decorative thumbscrews (Fig. 6,b), and an inscribed cupreous plaque that was too badly broken to read the inscription, were with the coffin. The weight of the grave fill had compressed the burial to the extent that it was on $1 y$ approximately 1.5 inches thick, measuring from the top to the bottom of the coffin. Although the other burials also were compressed, this burial exhibited the most extreme compression. No burial goods were found.

\title{
Grave F
}

Grave $F$ contained the infant daughter of D. P. and M. E. Johnson, Dasha Lee Johnson. The infant died at the age of 11 months and 20 days. The grave had a marble headstone with an arched top, which had the inscription "DASHA LEE, DAU. OF D. P. \& M. E. JOHNSON, BORN JULY 29, 1891, DIED JUNE 20, 1892, BUDDED ON EARTH TO BLOOM IN HEAVEN." The headstone a 1 so had a carving of a flying dove carrying a branch, which was within a circular out 1 ine with a dotted border. The footstone was also marble, and was engraved "D. L. J." The grave was bordered with a single row of handmade bricks which Brown (1986) observed had been removed from the nearby Grave E brick crypt.

The grave had a dug vault. The coffin exterior was painted with white gesso or paint and had a slightly tapered oval glass front that measured 6 inches by 14 inches. The rectangu 7 ar coffin had a wooden 1 id. The wood collected from this grave could not be identified. Hardware with the coffin consisted of hollow half-hemispherical studs, white metal and iron thumbscrews--one which was inscribed "AT REST," white metal handles, and a metal plaque inscribed "OUR DARLING." A doubled cotton fabric 1 ined the coffin. The cloth was twilled with an over 3, under 1 pattern, and the fabric warp was ztwisted with 64 threads to the inch. A fragment of a copper tack shank, and the hole for another tack which was one inch away from the first tack, were found in a remnant of the coffin fabric. The tacks were probably used to attach the cloth to the coffin interior. No burial goods were found.

\section{Grave $G$}

Grave G, located in a fenced plot near (Grave H) Jane Ivy, contained the remains of Caroline Myers, the daughter of Jane Ivy (Grave H) and wife of John Myers. Caroline Myers died at the age of 71 years. The square obelisk marb 1 e headstone was inscribed "CAROL INE M., WIFE OF JOHN MYERS, BORN APR. 18. 1833, DIED MAR. 4, 1904," and also had the verse:

\author{
Fold her, O Father, in Thine \\ arms, \\ And let her henceforth be \\ A messenger of love between \\ Our human hearts and thee.
}

The base of the headstone was inscribed "MYERS." Designs on the headstone consisted of a circular ornament, a sheaf of wheat, a gothic cross centered in a diamond design, five-sided flowers known as "witches feet" (Jordan 1982:Fig. 5-32; Brown 1986), and a 1ily. A marble footstone, engraved with 
"C. M. M." also marked the grave. A terra-cotta flower pot and purple glass were found in the vicinity of this grave and the Ivy (H) grave.

The grave had a dug vau 1 . An unidentified material, which was thought to possibly have been part of a hinge or a broken lowering strap for the coffin, was against the south side of the coffin. A sample of the material was examined in the 1 aboratory, but could not be identified; it did not appear to be fabric or leather, however. The pine coffin was narrow and rectangular with canted corners, and the exterior was covered with fabric. The fabric on the coffin exterior was a matted wool fabric identical to that found in Grave B. A cluster of what appeared to be dark brown hair was found in the abdominal region of the skeleton; the material was identified as nonhuman hair (it was flattened in cross section), and probably served as padding between the coffin and the coffin lining. The coffin had an oval glass front that measured 12-14 inches by 28 inches. Coffin hardware consisted of cast white metal handles that once had wooden grips, iron thumbscrews, and a leafshaped decorative stud (Fig. $6, C$ ). No burial goods were found.

\section{Grave H}

Jane Ivy, the mother of Joseph Ivy and Carol ine Myers (Grave G) was buried in

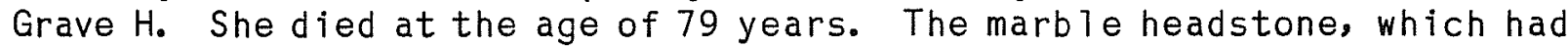
fal 1 en, was inscribed "MY MOTHER, IN MEMORY OF JANE IVY, BORN AUG. 4, 1812, DIED JULY 10, 1891," and had the verse:
Dearest mother, thou hast left us,
And thy loss we deeply feel,
But ' $t$ is God that hath bereft us,
He can all our sorrows heal,
Yet again we hope to meet thee,
When the day of 1 ife has fled,
When in heaven with joy to greet thee,
Where no farewell tear is shed.

A geometric design formed of triangles framed the name, and scroll symbols and a rose framed by an oval 1 ine, with a series of smal1 triangles, also decorated the headstone. A marble footstone inscribed with "J. I." also marked the grave.

The grave had a dug vault. The hexagona 1, hardwood coffin had an oval glass front that measured 10 inches by 24 inches. Coffin hardware consisted of hollow half-hemispherical studs, white metal and iron thumbscrews (Fig. 6,d), and white metal handles. No burial goods were found.

\section{Grave I}

An infant, approximately nine months of age at the time of death was buried in Grave I. The rectangular coffin was painted with white gesso on the exterior, and was 1 ined with fabric (no sample was recovered for analysis). The coffin had an oval glass front that measured 12 inches by 32 inches. The 
coffin hardware consisted of hollow half-hemispherical studs, two white metal handles, and iron nails. No burial goods were found.

\section{Grave J}

Grave J was extensively disturbed by two trenches. The size of the coffin (rectangular) indicated an infant or small child was buried here. The grave had a dug vault. The coffin exterior was painted with white gesso or paint. Either the vault planking or the coffin was made of pine. Hardware with the coffin consisted of hollow half-hemispherical metal studs, iron thumbscrews, and white metal handles. No burial goods were found.

\section{Grave K}

Grave $K$ was disturbed by trenching. The burial was of an infant or young child, judging by the dimensions of the pine vault planking for the dug vault, which measured 2 feet 5 inches by 2 feet 10 inches. The rectangular coffin, which may have been built of pine, was less than 1 foot 4 inches wide, the width of the exploratory trench. Ornate white metal handles (Fig. 6,e) were the on $7 y$ evidence of hardware from the coffin. No burial goods were found.

\section{Grave L}

Grave L contained an infant, approximately six months of age. The grave had a dug vault. Either the vault planking or the rectangular coffin was made of cf. Salicaceae. The coffin had a rectangular glass front with canted corners that measured 5.73 inches by 21 inches. The side of the coffin was 12 inches high. The coffin hardware consisted of iron naj1s, star-shaped cupreous studs, white metal and iron thumbscrews, two-piece white metal handles with the inscription "ONLY SLEEPING" (Fig. 7,a), and a white metal plaque with the inscription "OUR LOVED ONE" (Fig. 7,b). A safety pin with attached fabric, which was located in the abdomen area and probably served to fasten a diaper, was the only personal item found with the burial. The fabric attached to the pin was actually three layers of fabric. One layer was a tan cotton fabric twilled in an over 3, under 1 pattern; the warp and the weft were both ztwisted with 48 threads to the inch. Another 1 ayer was a poor 1 y preserved cotton fabric--the analysis was done from impressions left as a consolidated mineral coating, plus occasional strands of original fabric; the warp and the weft were both $z$-twisted with 72 threads to the inch. The other layer was a wool fabric in a plain weave; the warp and weft were both z-twisted with 32 threads to the inch. These probably represent, in order as described, a diaper, gown, and receiving blanket.

\section{Grave M}

Grave $M$ contained a child of approximately two years of age. The rectangular coffin, which may have been pine, was in a dug vault. The pine vault planking measured 3 feet 11 inches by 2 feet 5 inches, and was 11 inches 
Figure 7. Coffin Hardware from Graves $L, N, 0$, and $T$.

a, a white metal two-piece handle with the inscription "ONLY SLEEPING," from Grave L;

b, a white metal plaque with the inscription "OUR LOVED ONE," from Grave L;

c, a cast white metal plaque with an indecipherable inscription, from Grave $\mathrm{N}$;

d, a white metal two-piece hand 1e, from Grave 0;

e, a decorative white metal thumbscrew, from Grave T. 

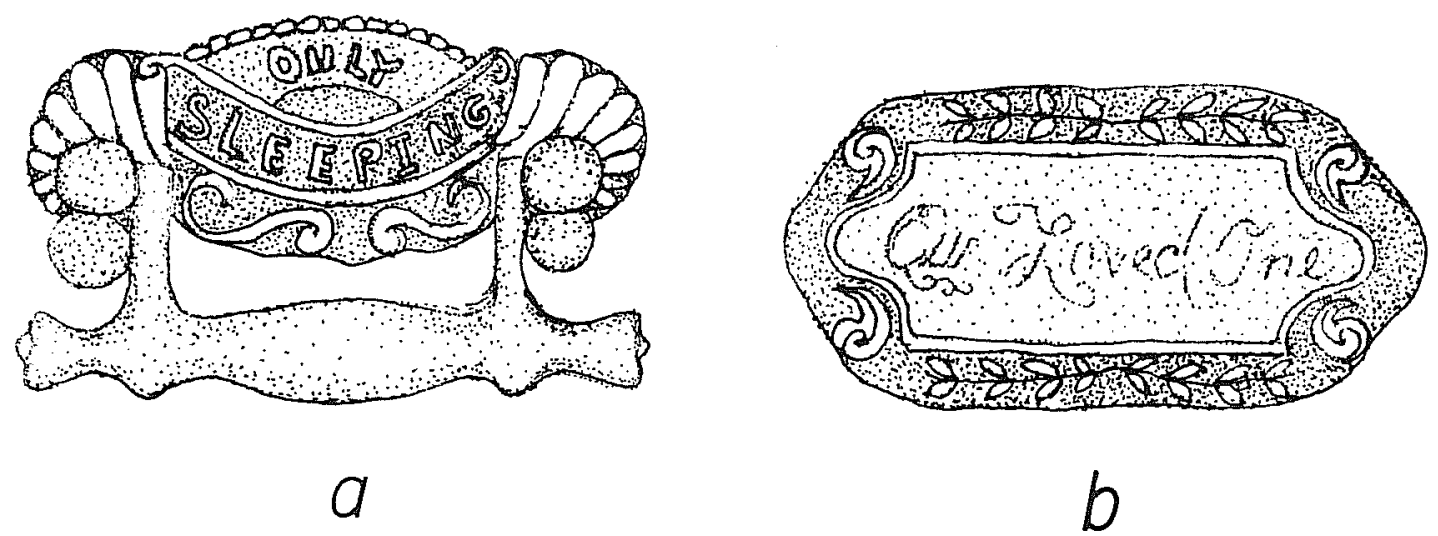

b

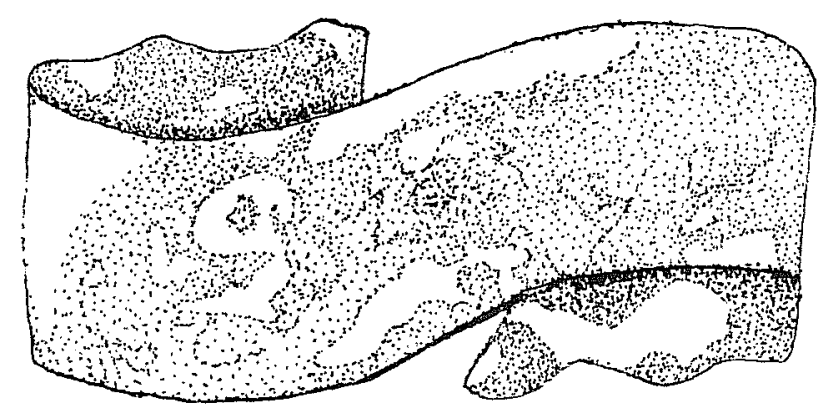

c
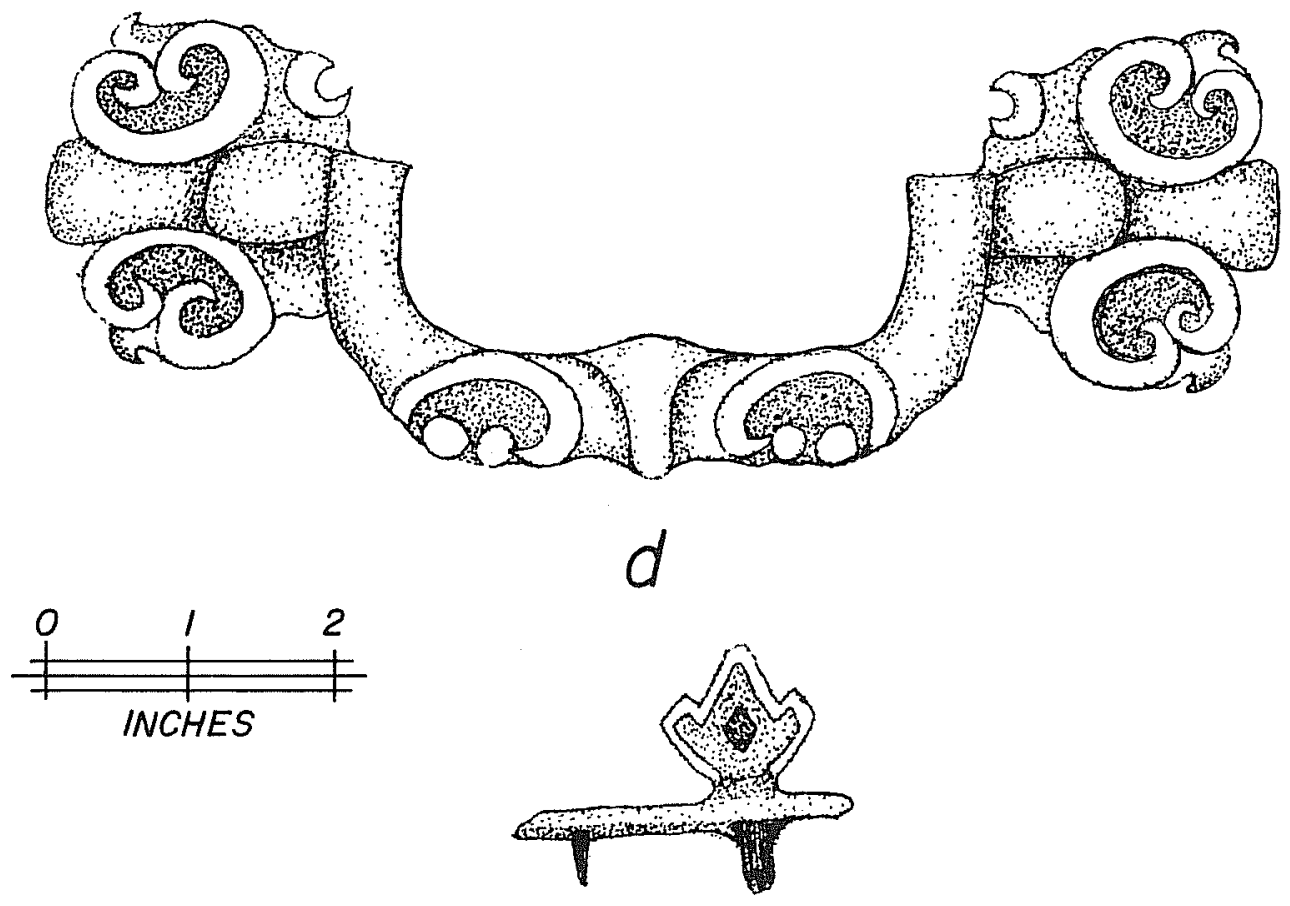

e 
above the top of the coffin. On the top of the coffin was a tapered ovoid glass front that measured 7 inches by 2 feet 3 inches. Also associated with the coffin were white metal ornaments, or studs, shaped 1 ike cal1a 1 ilies ( $F$ ig. 8,C), iron thumbscrews ( $F$ ig. 8,a,b), two-piece white metal handles with the inscription "OUR DARLING" ( $F i g .8, e)$, and a white metal plaque with the inscription "OUR DARLING" (Fig. 8,d). The individual's hands were crossed across the waist area. No burial goods were found.

\section{Grave N}

Grave $N$ contained an adu1t, possibly ma1e. Un1 ike the other buria1s, this individual was buried with the face down. As noted by Massey (Appendix A), the downward positioning of the face may be either deliberate or accidental. The rectangular coffin was enclosed in a coffin box, rather than having a dug vault. The coffin was 1 ined with what was thought to be remnant purple fabric. Analysis of this material determined that this purple material was not fabric--or at least there was no remaining fabric or fabric imprints, and also did not appear to be paint or gesso. It may have been a dye or stain which impregnated a thin layer of soil, though the source of the dye is unknown. The thumbscrews for the coffin box and coffin were iron, and the onepiece coffin handles were iron also. A cast white metal plaque with an inscription (Fig. 7,C), which was indecipherable due to the corroded condition of the metal, was also with the coffin. The individual's arms were folded beneath the region of the chest. No burial goods were found.

\section{Grave 0}

Grave 0 contained a robust adult of unknown sex. This burial was disturbed by trenching, and the skeletal material was further disturbed by rodent activity. The grave had a dug vault with vault planking which measured 1 foot by 2 feet 11.5 inches. The rectangular pine coffin was 1 ined with the same purple substance that was in Grave $N$, but in this case it appeared to contain some fibers which could not be identified and had no particular patterning. The coffin hardware consisted of metal studs, iron thumbscrews, two-piece white metal handles (Fig. 7,d), and a cast white metal plaque with an inscription that we could not decipher due to the poor condition of the metal. The individual's femur had been injured and healed before death. No burial goods were found.

\section{Grave $P$}

Grave $P$ contained an infant approximately six months of age or 1ess. The grave had a dug vau $1 \mathrm{t}$ which measured 1 foot by 2 feet 1 inch. The rectangular pine coffin was 1 ined with fabric (no sample was taken for analysis). The coffin hardware consisted of iron latches, iron hinges, white metal handles, and a white metal plaque inscribed "OUR DARLING." No burial goods were found. 

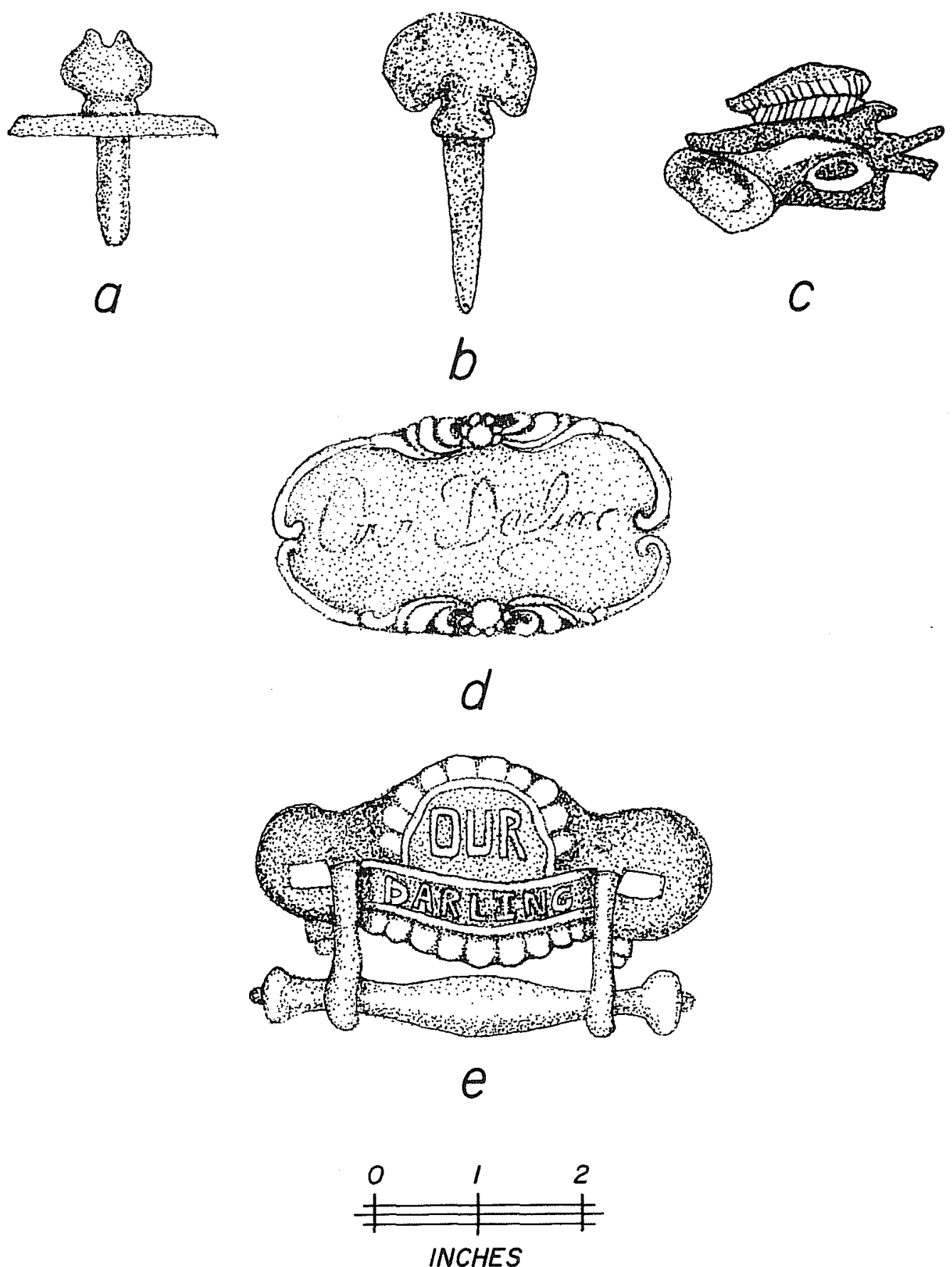

Figure 8. Coffin Hardware from Grave M. a, b, two types of decorative iron thumbscrews, from Grave $M$; $C$, a white metal ornament, or stud, shaped 1 ike a calla lily, from Grave $M$; d, a white metal plaque with the inscription "OUR DARLING"; e, a white metal two-piece handle with the inscription "OUR DARLING," from Grave M. 


\section{Grave 0}

Grave 0 contained an adolescent of approximately 12 to 15 years of age. The grave had a dug vault with pine vault planking that measured 2 feet 7 inches by 5 feet 9 inches. The rectangular pine coffin was within the size range for an adult, rather than the size range for a child. The side of the coffin measured 1 foot 1 inch high. The coffin was 1 ined with cream-colored fabric (a sample was not taken for analysis), and dark brown fuzzy fibers were associated with the skeletal material. The brown material was made of thin layers of felted wool fibers melded together. The material had no discernible weave or pattern. The coffin hardware consisted of poorly preserved, rosette-shaped, cupreous studs; iron thumbscrews; and white metal handles. The skeletal material had been disturbed by rodent activity. No burial goods were found.

\section{Grave $B$}

Grave $R$ contained an infant, possibly a newborn. The rectangular coffin was placed in a dug vault. The pine vault planking measured 2 feet 5 inches by 3 feet 7 inches. The coffin may have been built of cherry wood. The coffin exterior was painted with white gesso or paint, and had a glass front that was narrow and long with rounded sides and corners. Corregated iron fasteners, in place of nails, were set into the corners of the coffin. A few square nails were also associated with the coffin. Metal studs, a white metal 1 atch, and white metal handles with the inscription "OUR DARLING" constituted the coffin hardware. Ten small turquoise-colored glass beads, some of which were stil1 strung on a wire, were found near the area of the neck; the beads appeared to have been part of a decorative pin. Three white glass, four-hole buttons, 0.75 inches in diameter, and two half-hemispherical bead metal studs were also associated with the individual.

\section{Grave S}

Grave $S$ contained an infant, probably newborn. The pine coffin was rectangular. Hardware with the coffin consisted of only iron tacks and numerous iron nails. Associated with the skeletal remains was an impression of a plain weave cotton fabric of which some fibers were preserved and were clinging to an unidentified smooth, thin material. An impression of coffin wood was on the opposite side of the unidentified material. The cotton fabric was $z$-twisted, and the warp and weft had 64 threads to the inch. A safety pin, which probably served as a diaper pin, was found in the area of the abdomen.

\section{Grave T}

Grave $T$ contained an infant. The coffin was in a dug vault with pine planking that measured 1 foot 8 inches by 2 feet. The preserved side of the coffin, which may have been cherry wood, was 9.5 inches high. The exterior of the coffin was painted with white gesso or paint. A thin, purple stain similar to the purple stain in Graves $N, 0$, and $U$, was inside the coffin. 
The coffin hardware consisted of cupreous half-hemispherical studs (one inch in diameter), white metal and iron decorative thumbscrews (Fig. 7,e), and a cupric plaque inscribed "OUR DARLING."

\section{Grave U}

Grave $U$ contained a tall adult, and the clothing found with the burial suggests the individual was female. This was the deepest burial in the cemetery, with a depth of 6 feet 2.5 inches. The hexagonal cherry wood coffin was placed within a coffin box, and was in a dug vault. The pine vault planking was very well preserved, and was 3 feet by 6 feet, with the individual planks 7.5 inches by 3 feet. Some vault planks were curved on one side, indicating they were cut from an unshaped log. The side of the coffin was 10 inches high. The exterior of the coffin was painted with white gesso or paint. The coffin interior was painted gold. A purple stain 1 ike that found in Graves $N$ and $O$ (originally thought to be fabric) was found against the gold paint inside the coffin. The coffin hardware consisted of hollow half-hemispherical metal studs, two-piece white metal hand 1 es (Fig. 9,b), white metal and iron thumbscrews, small flat iron pieces, and a cupreous plaque inscribed "AT REST" (Fig. 9,a), which was over the chest area. A sma 11, four-hole white glass button was located in the throat area. On the wrists, which were folded across the pelvic area, were wel1-preserved cuffs which had metal snaps (Fig. 9, C). The reddish brown cuffs were made of a double layer of very fine plain weave cotton fabric which was 1 aminated with a stiffener; the material readily split into two layers, exposing the fabric, and the warp and weft were both z-twisted with 80 threads to the inch. Two long, slender cupreous clips were associated with the cuffs. Also associated with the burial was a plain weave wool fabric which was z-twisted; the warp had 48 threads to the inch, and the weft had 32 threads to the inch. A third fabric, possibly wool, was attached to the previously mentioned wool fabric, and had a plain weave with 80 threads to the inch for both the warp and weft. A metal hook used to fasten clothing was found in the waist area.

\section{OBSERVATIONS}

A 1 though the blading of any cemetery or other archaeological site, is not advised as a general practice, this method proved to be 1 ess damaging and more reliable for 1 ocating burials at Morgan Chapel Cemetery, than did trenching. However, in cemetery sites where grave out 1 ines can be distinguished, blading of the topsoil to expose grave pits would be the most advisable technique for locating unmarked graves.

Some of the burials reported for Morgan Chapel Cemetery by 1 ocal informants were not found during the removal operations. Three to four of the unmarked graves ( $L, M, N$, and possibly $K$ ) were grouped together-Graves 0 and $P$ may have also been included in this grouping ( $F$ ig. 4 )--and may have marked a family plot similar to the Cruse family plot (Graves A-D), and the Ivy and Myers plot (Graves G-H). Graves L, M, and $N$ were noted to al 1 be p 1 aced roughly 41 inches apart with the western end of the coffins aligned, with Grave $K$ a short distance to the north, and Graves 0 and $P$ also nearby to the north. The volunteer irises in the eastern part of the cemetery may al 1 have 

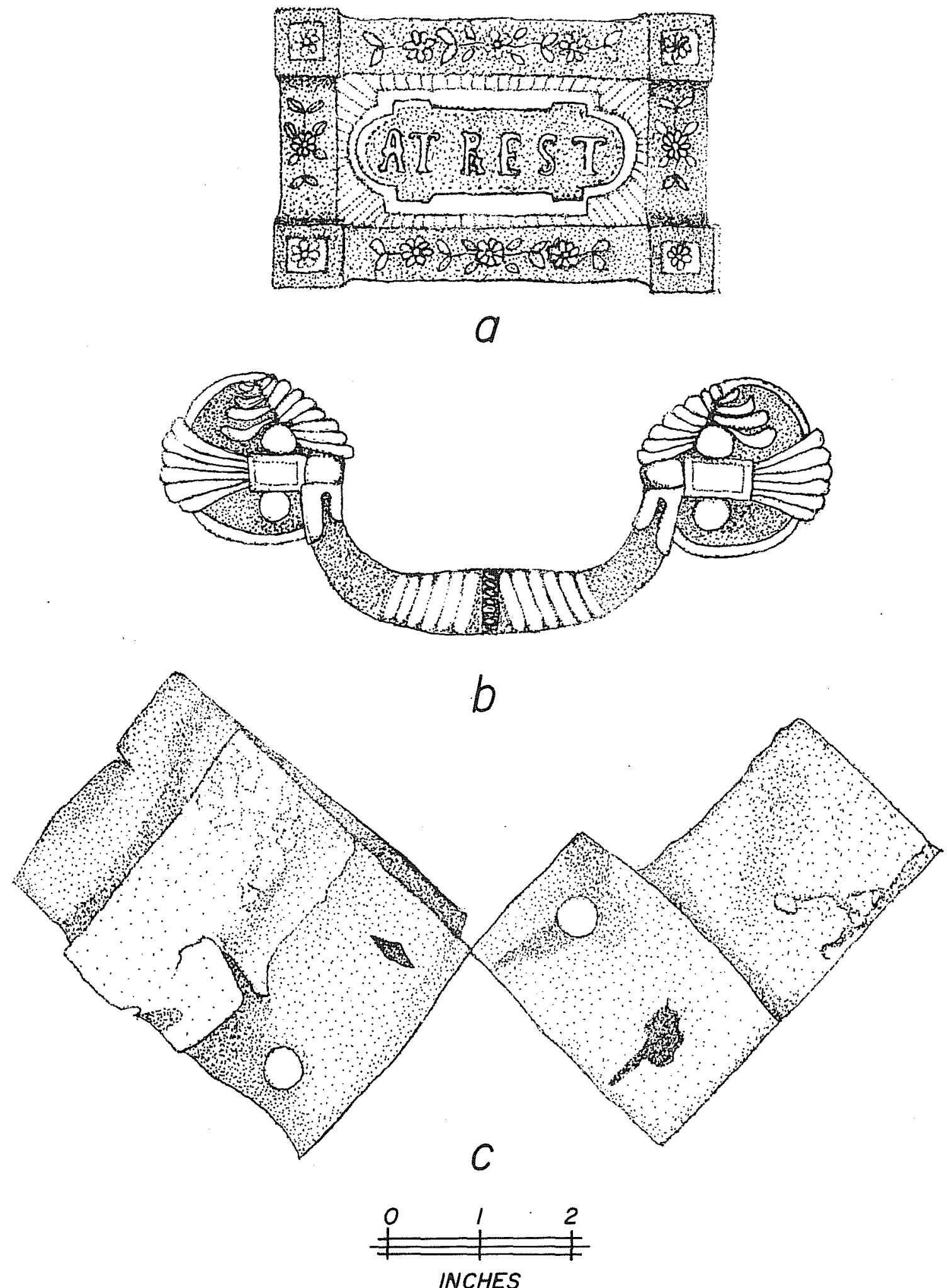

Figure 9. Metal Hardware from Grave U. a, a cupreous plaque inscribed "AT REST," from Grave U; b, a two-piece metal handle from Grave U; c, two cotton cuffs with metal buttons found on the wrists, from Grave U. 
been original1y planted to mark the graves in the Cruse family plot, or perhaps the northern bed of irises was planted to mark Graves $K-N$, and possibly also Graves $O$ and $P$. Although it is possible, considering the results of the osteological analysis, that burials in Graves K-P may have been members of the Dunbar family, which were reportedly buried together in a family plot at Morgan Chape 1 Cemetery, this is not certain. The location of these graves is on the northern side rather than the reported southwestern to western side of the cemetery. The skeleton in Grave $N$ was tentatively identified as that of a male and, if so, was not that of H. D. Dunbar's grandmother, Virginia Elizabeth Hewitt Biggers, though the possibility that the remains are the grandmother has not been ruled out entirely (Appendix $A_{\text {; }}$ Massey 1984). It should be noted that the remains in Grave 0 included a femur which showed signs of trauma which occurred prior to death, which may correspond to reports that Virginia Elizabeth Hewitt Biggers was injured in a train wreck prior to her death (Dunbar 1984).

\section{Burial Customs}

Before the advent of commercial "funeral homes," the corpse was "1aid out" by the local people. Friends of the deceased kept a watch over the body, made the coffin, and dug the grave. Since the body was not embalmed, buria 1 usually occurred the day after the death. The corpse was often transported to the cemetery in a wagon, with a quilt or 1 ayer of hay in the wagon bed to absorb some of the shock (Killen 1974:248). If there was no preacher residing in the vicinity, the friends and family conducted the burial, and a memorial service was held later when a preacher was in the area. The cemetery was maintained at certain times of the year by relatives of the deceased, during which time grave mounds were rebuilt, the ground cover was cut or removed, and flowers and other commemorative items were placed on the graves. Unfortunately, with the depopulation of rural areas, the maintenance of rural cemeteries has declined or ceased (Jordan 1976:154, 1982:2528; Taylor 1975b; Fox 1984:52, citing Roberts 1950:160 and Wigginton 1973:304-323). In nearby Elgin, Texas, the Miller Funeral Home was founded in the 1900s, indicating that commercial preparation of the deceased began in this area by at least the early 1910s or 1900s (Newby 1984).

\section{Cemeteries}

Of the eight marked graves at Morgan Chapel Cemetery, six (28.6\%; Graves A-D, $\mathrm{G}-\mathrm{H}$ ) were in the two family plots (Fig. 4). Others were clustered together, and may have been in a family plot. The five burials of Dunbar family members that were reported for the cemetery, but were not positively identified, were reportedly placed together in a family plot. Burials within the marked family plots were placed in a single row. The wide spacing of the burials in these marked family plots may indicate that the families anticipated burying additional family members in Morgan Chape1 Cemetery. Jordan (1976:156-157) observed that multifamily rural cemeteries in north Texas were usually divided into family plots.

The a 1 ignment and centering of Graves $E$ and $F$ in relation to graves in the Cruse family plot is noted by Brown (1986), who observes that this spatial 
arrangement may indicate kinship between these individuals. Tombstone inscriptions, however, show that Grave F, Dasha Lee Johnson, predates Graves A and B, Wi 11 iam F. and Ann Cruse. Also, if Brown's (1986) speculation that Grave $E$ is one of the earliest burials in the cemetery is correct, then Grave $F$ may also predate the Cruse burials and could not have been placed relative to them. It is possible that Graves $E$ and $F$, and the burials in the Cruse family plot (A-D), were all aligned in relation to Grave $\mathrm{H}$, Jane Ivy, the earliest reported burial in the cemetery; or perhaps the other graves were aligned with Graves $E$ and $F$.

There are several small rural cemeteries in the vicinity of Morgan Chapel Cemetery, some of which are strictly family cemeteries and are not affiliated with any church (Casey 1980). Carter and Ragsdale (1976:98) note that the German family cemeteries of Biegel's Settlement in Fayettevilile County, Texas, were predominantly located "along old roads in the pastures, generally on a rise and under large oak trees." The smal1 historic cemeteries in McMullen and Live Oak Counties, Texas, reported by Fox (1984) were likewise located in rural settings.

Rural cemeteries of the 1 ate 1800 s and early 1900s, such as Morgan Chape 1 Cemetery, are unlike the crowded, unsanitary graveyards which prevailed prior to the middle to 1 ate 1800s. Graveyards of the $1600 \mathrm{~s}$ and early $1700 \mathrm{~s}$ in the northeastern United States were directly connected with a church, and burials were crowded into the 1 imited designated area, often with no regard to location of previous burials. During the later 1700s, small family plots with designated individual graves first occurred; at that time in the South, individual family plots were often used instead of community burial grounds (see Fox and Livingston 1979:9, Fig. 4,b; Freeman and Fawcett 1980:127, 131; Fox 1983:156), but often did not survive changes in 1 andowners and were obliterated for other uses. Cemeteries with designated lots first occurred during the early 1800s. Rural cemeteries, some of which were not affiliated with a church, also developed during this period as a necessity in sparsely settled frontier areas far from any church. Transportation of the dead to the nearest church in isolated frontier locations was quite difficult if not impossible. Burial in a cemetery associated with a church eventually was not considered as being particularly advantageous. Such burial in unsanctified ground appears to be a continuation of the dissenter British Protestant tradition which opposes the consecration of burial grounds (French 1974:7172; Jordan 1976:157, 1980:228, 1982:33-34; Fox 1984:47, citing Deetz $1977: 90)$.

\section{Eences}

The two marked family plots at Morgan Chapel Cemetery were del ineated by ornamental iron fencing (Figs. 2,a; 4). Another 1 arge iron fence, west of the Ivy (Grave H) and Myers (Grave G) family plot, and a wooden fence, around a single grave, were also reported for the cemetery (Biggers 1984; Casey 1984).

The practice of fencing family plots and cemeteries with ornamental ironwork dates to the 1840s. Such fencing is common in cemeteries in Texas and the rural South which date to the middle to 1 ate 1800 s and early 1900 s (French 
1974:83; Jordan 1980:228, 246, 248, 1982:38, 98-100). Four of the five cemeteries described by Fox (1984:52) had wooden, stone, and iron fences or wa11s.

\section{Graves}

Morgan Chape 1 Cemetery was overgrown with brush, and grave mounding was not evident. The neglected state of the cemetery prevents any definite statement concerning whether or not grave mounds were present or if the cemetery was scraped. Many cemeteries in the South have grave mounds which serve to drain water, and to mark the location of the graves. The use of grave mounds appears to be a custom which originated in Britain. Scraped or bare earth cemeteries are present throughout the South (Jordan 1976:153-154, 1980:234, 1982:14-16), and at least one such cemetery has been reported near Morgan Chape 1 Cemetery (Stuard 1984). The custom of graveyard scraping may have originated in Africa (Jordan 1982:14, 16).

Grave depths at Morgan Chapel Cemetery varied from 3 feet 9.5 inches to 6 feet 2.5 inches. The average grave depth was 4 feet 8 inches for infants (one year of age or 1ess), 4 feet 9 inches for children, and 5 feet 1 inch for adults (Table 3). This confirms McIntire's (1984) statement that graves are usually dug to 5.5 feet or less below ground surface. Fox (1984:49) reported more shallow average grave depths for the graves in five south Texas cemeteries with 3 feet 3 inches to 3 feet 11 inches for infant and child graves, and 4 feet 4 inches for adult graves. A hard subsoil of unconsolidated sandstone was encountered at a relatively shallow depth in those cemeteries, however, which probably affected the grave depths.

Rogers and McReynolds (1981:88), Blakely and Beck (1982:186), and Fox (1984:49) observed that the grave pit size roughly correlated with the coffin size, and the coffin size also related to the individual's size. Although the grave pit outlines could not be distinguished at Morgan Chapel Cemetery, the coffin size and individual's size were observed to be closely related. The false crypt associated with Grave $E$ al so approximated the size of the coffin and the individual's size; the moderate size of the crypt (4 feet 4 inches in length) led Brown (1986) to speculate, correctly, that the burial was that of a child.

Sixteen (76.2\%) of the 21 graves at Morgan Chapel Cemetery had dug vau 1 ts (Figs. 2,a; 10,f,g, this report; Blakely and Beck 1982:188, Fig. 8.5), and four (19.0\%) had boxes into which the coffins were placed; one of these four coffins also had a dug vault. The remaining two (9.5\%) burials were protected solely by coffins (Table 2); it is possible that a thin coffin box may have been present with these burials, and may have gone unnoticed. One grave (Grave $U$ ) had vault planking with extremely well-preserved planks made of unshaped logs and a wooden box that contained the coffin. In graves with dug vaults, the central part of the vault planking had collapsed from the weight of the overlying grave fill. Often the sides of the wooden coffins had collapsed inward, which resulted in the coffin handles being located in the central part of the burial. The coll apse and crushing of coffins from the overburden sometimes made the identification of coffin form difficult. No octagonal-shaped coffins were identified, but it is possible that some of the 
coffins recorded as being rectangular or hexagonal forms, may have instead been octagonal.

The coffin was lowered into the grave, and into the dug vault if one was present, with buggy 1 ines from which the buckles had been stripped, or with patent straps which attached to a bracket on the side of the coffin. The buggy lines or patent straps were slipped out from around the coffin once it was set into place. Next, wooden planking was $p l$ aced across the shelf or step of the grave pit formed by the dug vault, at right angles to the 1 ong axis of the grave (Figs. 2,b; $10, f, g$ ). The grave was then ready to be $f j l l e d$ (C lark 1974:232). The vault planking served as a protective covering to help prevent the coll apse of the wooden coffin under the weight of the grave fill. After 1930, wooden vault planks reportedly were replaced by metal supports for burials with wooden coffins (Blakely and Beck 1982:188; Fox 1984:49).

In many of the graves 1 ight tan sand and silty b 1 ack clay had sifted and washed into the lower grave pit around the coffin and the vau 1 t. A 1 ight gray, abrasive material was also observed above and around 13 (61.9\%) burials (Tab 1e 2); however, it may have been with more of the burials, since this trait was not systematically noted until the later part of the project. This material may have been quicklime which would have been added to avoid contamination, particularly in cases when there was a longer than usual delay between death and burial (McIntire 1984). Results of soil tests for the gray sandy material from Graves $I, J, M, 0$, and $P$, and also a comparative sample of naturally occurring sand from the site (Table 4), show that the levels of calcium in the samples of gray sandy material are much higher than that for the in situ sand, which would be expected for 1 ime, although these results do not definitely prove that this material was 1 ime (Lewis 1984). At the Laredo Cemetery, McReynolds (1981b:34) noted that one coffin had 1 ime scattered within it. The 1 ime was speculated to have been used to guard against contamination, particularly in instances when individuals died of disease.

TABLE 4. LISTING OF THE CALCIUM LEVELS FOR THE GRAY SANDY SOILS FROM GRAVES I, J, M, O, AND P, AT MORGAN CHAPEL CEMETERY

Grave Calcium

\begin{tabular}{cc}
\hline I & 1040 high \\
J & 4000 very high \\
$M$ & 680 medium \\
0 & 2840 high \\
$P$ & 920 medium \\
C.S.* & 560 low \\
\hline
\end{tabular}

*C.S. = Comparative sample of natural1y deposited, in situ sand from Morgan Chape1 Cemetery.

The soil test results were obtained from the Soil Testing Laboratory of the Texas Agricultural Extension Service, Texas A\&M University System, College Station, Texas. 
Grave Markers

The absence of tombstones or markers on many of the graves at Morgan Chape 1 Cemetery may be at least partially due to the deterioration of wooden grave markers, or the displacement of unworked petrified wood grave markers, and it is possible that some of the graves may have had wooden markers. Unworked stone and wooden markers are found with older burials in Texas and in the South (Jordan 1982:41-47). Many of the graves in the rural north Texas cemeteries examined by Jordan (1976:157) had no markers, and a few had o1d wooden markers which had survived. As mentioned earlier, some gravestones may have been removed by an occupant of the site during the early 1950s. Of the 34 graves described by Fox (1984:51-52), on 7 y nine (26.5\%) had stone grave markers, one had a wooden marker, and others had on $7 y$ unmarked fieldstones.

Five (23.8\%) of the graves at Morgan Chape1 Cemetery had headstones, and a 11 appeared to have been commercially made. One grave had a brick false crypt. The headstone and footstone inscriptions a 11 faced east, un 1 ike the Anglo Protestant gravestone inscriptions observed by Jordan (1976:158) in north Texas, which usual1y faced west. The gravestones were similar to those described by Jordan (1976:157), in that they were "modest in size and [the] epitaphs [were] short and to the point." Inscriptions and decorations on the headstones included the deceased's name and/or initials, their relationship to others (daughter, mother), date of birth, date of death, commemorative verses, Gothic crosses, scrol1s, gates of heaven, doves which sometimes carried an olive branch, a wreath, a sheaf of wheat, and floral designs which included a rose, 1ilies, and "witches' feet." The graves in the Cruse family plot (Graves A-D) were outlined with one to two rows of brick, and the family plot was also out 1 ined with brick. The use of brick on these and other graves in the cemetery is probably due to the proximity of the Butier Brick Company to the cemetery, though this custom is not uncommon in the rura 1 South (Jordan 1980:228, 246, 248). In some areas of the South, brick crypts may be symbols of family wealth. Also, the covering of graves with concrete may occur when families anticipate that the grave will not be maintained, and the concrete covering then serves as a more permanent grave mound that does not require periodic maintenance (Jordan 1976:154). The construction of a brick vault would appear to be less of a sign of wealth at Morgan Chape 1 Cemetery, which is in a brick manufacturing area, than it might be elsewhere. Perhaps the vault was intended to serve as a long-term grave mound. False crypts, though uncommon, do occur throughout the southern United States (Jordan 1976:154, 1982:18-10). Eleven (32.4\%) of the 34 graves exhumed from cemeteries in Live Oak and McMullen Counties in south Texas had false crypts or cairns built of sandstone or 1imestone slabs (Fox 1984:51-52).

The she 11 decoration on the Grave E false crypt is similar to one of the types of central Texas she11-decorated graves described by C1ark (1972:33). This particular grave type is covered with a concrete mound embedded with she11s which are placed concave side down. The shells are usually arranged over the entire concrete mound. Such graves were made by both amateur and professional cement finishers, and are found throughout the South. Kelly and Highley (1979:26, Fig. 2,a) observed she11-covered grave mounds in the Asher Cemetery (41 KA 53) in Karnes County, Texas, which date from 1905 to 1926. Brown (1986) suggests that the style of Grave E, with the handmade brick 
Figure 10. Coffin Shapes and a Dug Vault Grave from Morgan Chapel Cemetery (41 BP 200).

Coffin shapes:

a-d, rectangu 1 ar forms, Graves $A, P, B, G$ (c, d, with tapered sides and $d$, with canted corners);

e, hexagonal coffin, Grave H (d, e, glass fronts, or sealers, which were placed over the upper half of the coffin);

f, schematic cross section, Grave M;

g, Plan view of a child burial in a dug vault, Grave M. 

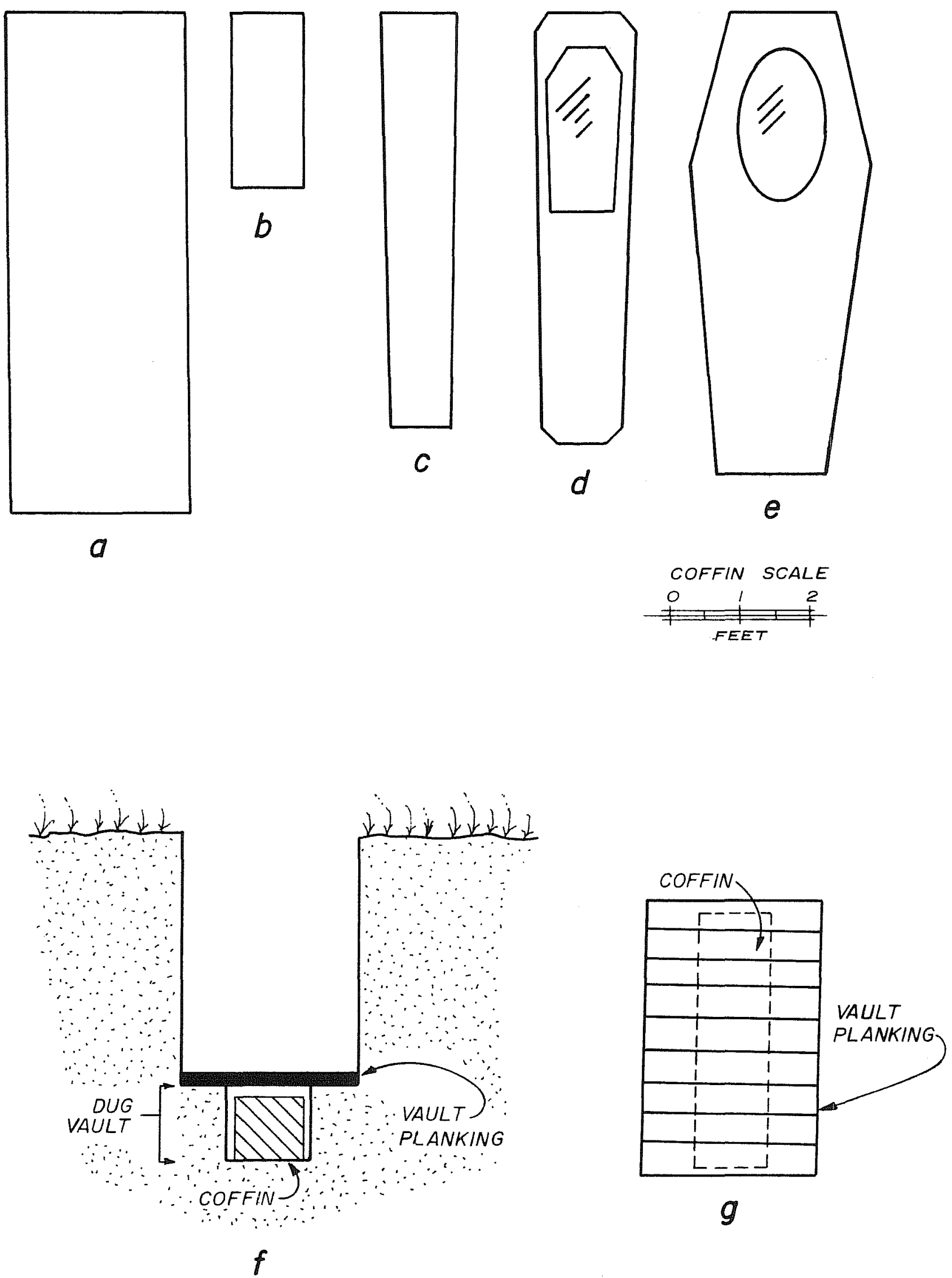
crypt and shel1 decoration, indicates that it is one of the oldest burials in the cemetery.

Additional decoration of the Morgan Chapel Cemetery graves included a terracotta flowerpot and a few pieces of purple glass found in the sandy topsoil of the Myers and Ivy (Graves $G$ and $H$ ) family plot. Beds of volunteer irises were growing in the vicinity of the Cruse family plot, and a cedar sapling was located south of the Myers and Ivy plot. In the rural South, the decoration of graves with objects is not uncommon. This custom may have originated in Africa and the British Isles. Southern cemeteries are also traditionally decorated with various trees and flowers, a custom which may have originated in the Middle East and the ancient Mediterranean. Irises and evergreen trees such as the cedar are particularly common in southern cemeteries (Jordan 1976:154-156, 1980:242-243, 1982:19, 21, 28-30). Freeman and Fawcett (1980:128, 131) reported that a double row of cedars was planted at the Brackenridge Cemetery, a rural family cemetery in Jackson County, Texas, which dates from 1856 to 1878.

\section{orientation}

A11 21 of the burials in Morgan Chapel Cemetery were oriented east to west, with the head to the west (Fig. 4). This orientation is standard for southern rural burials, and is based upon the belief that the deceased should be oriented so as to rise to face the rising sun on the day of judgment ( $\mathrm{Hi} 11$ 1968:86-88; Jordan 1980:246, 1982:30; Fox 1984:49, citing Puck 1e 1926:149). The location of Ann Cruse (Grave B), on the north side of her husband, Wi11 iam F. Cruse (Grave A), is customary in southern rural cemeteries. This positioning may be based upon a British folk belief that Eve was created from Adam's right side; it also duplicates the position a couple takes during wedding vows, with the woman on the left side of the man (Jordan 1980:247, 1982:30-31). The face downward placement of the corpse in Grave $N$, as stated earlier in this report, may be deliberate or accidental. Local residents told the archaeologists that a suicide was buried at Morgan Chapel Cemetery, and also that it was common to bury suicides face downward. Further investigations concerning the suicide victim, however, indicated that the individual was interred in another $10 \mathrm{cal}$ cemetery rather than in Morgan Chape1 Cemetery (Casey 1984; McWil1iams 1984). The face downward burial of an adult male was reported for a Negro cemetery in Philadelphia which dates approximately 1823-1841; the significance of the positioning of the burial was not reported, however (Wittkofski 1984). The on $7 y$ published account that the authors could locate, of the deliberate burial of individuals face downward, was for some executed Federal deserters during the Civil War. The deserters' graves were often unmarked as we11, to further indicate the individual's disgrace (Robertson 1984:155).

The orientation of the south Texas burials from Choke Canyon Reservoir reported by Fox $(1984: 42,49)$ was east to west with the head to the west, with the exception of one infant burial in which the head was to the east; the placement of this burial was thought to be an error rather than deliberate. At the Laredo Cemetery, all of the burials but one were oriented east to west, but the placement of the head was variable, with seven (31.8\%) having their head to the east and $15(68.2 \%)$ with their head to the west. 
The remaining burial, an adult, was oriented north to south, and the peculiar placement of the individual was speculated to be due to the time period in which the burial occurred, or because of the amount of space remaining in the cemetery at the time of burial (McReynolds 1981b:38, 62; Herrington and McReynolds 1981:Table 5). In rural southern cemeteries, graves aligned north to south general1y denote wrongdoers or, particularly, suicides. This tradition appears to have originated in Europe, and is mainly restricted to the British Isles (Jordan 1980:246, 1982:30). Another means of distinguishing suicides, or victims of violent or accidental deaths, from other burials was to bury the corpse at a crossroads (Hil1 1968:89; Farberow 1975:3). In some traditions, it was also the practice to inter suicide victims or "persons of a morally problematic nature" face downward, to indicate that the individual died from "morally questionable circumstances" (Wi11 is 1984).

\section{Coffins}

A1 1 the Morgan Chape 1 Cemetery burials were in wooden coffins. Nineteen (90.5\%) of the coffins were rectangular in form (Figs. 4; 10,a-d), with two of the rectangular coffins having canted corners (Figs. 4; 10,d). The remaining two (9.5\%) coffins were hexagonal shaped (see Figs. 4; 10,e, this report; Blakely and Beck 1982:Fig. 8.6). The earliest dated burial (Grave H) at Morgan Chape 1 Cemetery, dates to 1891, and has a hexagonal coffin; the other hexagonal coffin occurs with an unmarked grave (U) and is not dated, a) though the coffin form may indicate that it was one of the earlier burials at the site. The infant burials all had rectangular coffins. All the coffins described by Fox (1984:50), which date from 1860 to 1913, were wooden. The majority of the adult coffins from Choke Canyon (Fox ibid.) were hexagona 1, although a few were rectangular, and the coffins with the smallest infants were al1 rectangular. The Laredo Cemetery coffins, which date to the 1 ate $1800 \mathrm{~s}$ and early 1900s, were predominantly hexagonal (McReynolds $1981 b: 62)$.

During the Spanish colonial period in Texas, prior to 1800 , coffins do not appear to have been used in mission burials (Fox 1984:50). Hexagonal wooden coffins, which were also known as "truncated diamond," "pigeon toed," or "toe pincher" coffins, were the earliest style of coffin, and were first used during colonial times in the northeastern United States. In certain isolated areas of Texas, coffins were not used until as 1 ate as 1853 (01msted 1978:319). Hexagonal coffins were later rep 1 aced by octagonal1y shaped coffins. Rectangular, or straight-sided, coffins, which were referred to as caskets, appeared after 1850, and eventual1y replaced the octagonal shaped coffins. Octagonal wooden coffins then became 1 imited to the burial of individuals of the lower socioeconomic class.

Coffins were inexpensive and were usual ly constructed upon request by a 1 local carpenter or cabinetmaker until the time of the Civil War, and in some places in the rural South until 1915. The coffins were made of cedar, cherry, spruce, pine, walnut, or oak boards held together with long steel tacks. The coffin exterior might be partially covered with black cloth, and have dark stained wood. Coffin hardware was obtained wholesale by $10 c a l$ rural stores, and was often sold in assembled bundles with four handles and plaques with 
inscriptions such as "AT REST," or "OUR DARLING" (see Figs. 5-9). Gray, white, and black 1 ining for coffins was sold at the store by the yard. The predominant color for the coffin lining was black. After the Civil War, or after 1915 in some parts of the rural South, the cost of coffins rose considerably, and the number of coffin shops and varieties of coffins increased dramatical1y. Funeral homes, and the practice of embalming may have also become popular at this time (Whilden and Cox 1973:306, 311-313; Clark 1974:228-236; McReynolds 1981a:93-94, citing Harmer 1963:90-91, 106-107 and Coffin 1976:107; Rogers and McReynolds 1981:85; A T iaga 1984; and Fox 1984:50-51). McReynolds (1981a:95) attributes the increase in coffin styles and cost to a change in public attitude toward burials, with the purpose of coffins changing from simply being a burial receptacle to al so becoming a means of displaying status.

The wood used to construct the coffins at Morgan Chapel Cemetery included pine (Pinus), possibly cherry (cf. Prunus), and an unidentified hardwood (Angiosperm; Holloway, Appendix B). The two adult coffins from which samples were taken (Graves $H$ and $U$ ) were both hexagonal shaped, and both were made of cherry wood, which may indicate that these two coffins both date to the early usage of the cemetery around the turn of the century. The other cherry wood coffins were rectangular, as were al1 the subadult coffins. The remainder of the sampled coffins were made of pine, with the possible exception of Grave L, which may have been Salicaceae. All the sampled vault planking was pine. The usage of cherry wood for coffins was unexpected since al 1 the identified wood samples reported by Rogers and McReynolds (1981) for the Laredo Cemetery, and by Aliaga (1984) for the Choke Canyon cemeteries, were pine species.

There was considerable variability in coffin size at Morgan Chapel Cemetery (Tables 1 and 3 ). Coffins for infants and very young children one year of age or younger were rectangular, and averaged 1 foot by 2 feet in size. Child coffins had an average size of 1 foot 4 inches by 4 feet 3 inches; however, this average includes Grave $Q$ which had an adult-sized coffin." If the Grave 0 coffin is omitted, then the child coffins average 1 foot 1 inch by 3 feet 8.5 inches in size. Adult coffins averaged 1 foot 7 inches by 6 feet 2 inches. Some adult coffins (Graves B, G, H, 0) were very narrow, especially in comparison to the Grave A coffin, and appear to have been made for a close fit. The close correlation noted between coffin size and the size of the individual may indicate that the coffins were locally made for a specific individual, as is suggested by Rogers and McReynolds (1981:88). This would support accounts by $100 a 1$ informants that WiT1iam F. Cruse (Grave A) constructed some of the coffins. The 1 ater introduction of mass produced, machine made coffins would also have added to the variability in coffin size. The length of vault planking was also closely correlated to the coffin length, although the vault planking width was much wider than the coffin. The grave was probably dug only sijghtly longer than the coffin, to avoid unnecessary digging in the hard clay subsoil, but it would have been dug wider than the coffin to allow for elbow room while digging and to provide a shelf to support the vault planking. The vault planking was probably roughly the same size as the grave pit.

The exterior of seven (33.3\%) coffins was painted white with gesso or paint, and one had a gold painted interior in addition to a white gesso exterior 
(Table 2). Two (9.1\%) coffins from the Laredo Cemetery were painted, one of which was a dul1 red with yellowish ivory trim (McReynolds 1981b:43; Rogers and McReynolds 1981:Table 6).

G1ass fronts or sealers, were present in eight (38.1\%) burials (Table 2). The glass extended much of the length for infant burials; for adults, it covered only the upper half or third of the coffin (Fig. 10,d,e). The glass was cut into rectangular and ovoid shapes. There was a wooden 1 id on many coffins with glass viewing plates, which closed over the glass and wooden top. Patents for wooden coffins with glass viewing plates were filed between 1860 and 1900 in the United States, and were more expensive than the plain style of coffins. The purpose of the glass fronts on coffins may have been on $7 y$ for decoration, although there is some speculation that it may have truly served as a sealer on the coffin since embalming may have not been practiced, or may have been poorly developed at this time (Combes 1972; Dickens and B1ake1y 1979; McReynolds 1981a:93, citing Coffin 1976:101, 1981b:15, 43; and B 1 ake $1 \mathrm{y}$ and Beck 1982:188-189, 199-200, citing K 1 ine and K1 ine n.d.). No glass fronts were found in any of the south Texas burials reported by Fox (1984). One coffin (4.5\%) from the Laredo Cemetery had an oval glass front (McReynolds 1981b:43-44, 50, Figs. 14, 17).

Ornate coffin furnishings such as metal studs, white metal or iron handles and thumbscrews, and white metal or cupreous plaques (Figs. 5-9), were found with all the intact burials at Morgan Chapel Cemetery; and iron nails, used to construct the coffin, were found in al1 the graves. There was a wide range of designs exhibited in the coffin hardware. In constrast, only five (22.7\%) of the 22 coffins described for the Laredo Cemetery had any coffin hardware (McReynolds 1981b:Table 3). No coffin hardware was found with any of the 34 burials reported by Fox (1984).

\section{Grave Inclusions}

Very few personal effects were found with the Morgan Chape 1 Cemetery burials (see Table 1); 15 (71.4\%) burials had no evidence of personal articles, two (9.5\%) burials had only diaper pins, and one (4.8\%) burial had only a hair comb. The lack of grave goods in many of the burials may indicate that those individuals were buried in shrouds, or winding sheets, without shoes.

From the 1860 s through the 1910 s in the rural South, it was not unusual to bury an individual in a shroud made of bleached cotton fabric (C1ark 1974:234-236; see Fox 1984:53). Of the 22 burials in the Laredo Cemetery, only 12 (54.5\%) had any personal effects (McReynolds 1981b:Tables 3 and 4). Several of the burials reported by Fox (1984:53), however, had grave inclusions, al though no personal effects were found with many burials. There were straight pins in many of the burials with no inclusions, which Fox (ibid.) suggests were used to secure shrouds or winding sheets. Copper pins found with adult female and child burials were interpreted as indicating shroud burials at an early 1800s Negro cemetery in Philadelphia (Wittkofski 1984). According to Blakely and Beck (1982:188), it is not unusual for corpses to be buried without shoes. 


\section{SUMMARY AND CONCLUSIONS}

Twenty-one burials at Morgan Chapel Cemetery (41 BP 200) were relocated. These burials were all located in a concentrated area (Fig. 4) near a former church site. The known dates of the burials range from 1891 to 1937, a total of 46 years.

The results of Massey's (Appendix A) osteological analys is of the burials indicate there were seven (33.3\%) adults (Graves $A, B, G, H, N, 0, U$ ), of which one (4.8\%) male (Grave A), one (4.8\%) probable male (Grave $N$ ), and one (4.8\%) female (Grave B) were identifiable as to sex. There were also one (4.8\%) adolescent (Grave 0 ), one (4.8\%) young child (Grave M), and 12 (57.1\%) infants (Graves $C, D, E, F, I, J, K, L, P, R, S, T$ ).

Additional information concerning the burials was provided by headstones, informants, and data recovered by excavation for Graves $\mathrm{A}-\mathrm{H}$, which either had surface markers or were in del ineated family plots (Fig. 4, Tables 1-3). For these eight marked graves there were four adults (Graves A, B, G, H), one subadult (Grave $E$ ), and three infants (Graves $C, D, F$ ). According to sex the adults were one male (Grave $A$ ) and three females (Graves B, G, $H$ ), and they ranged in age from 65.5 to 81 years. The subadu $1 t$ (Grave E) was of unknown age and sex. Of the three infants, two were female (Graves $D, F$ ), and the sex of one (Grave $C$ ) is unknown.

Data from the Miller Funeral Home Records (1911-1950) and informants (Casey 1980, 1984; Odiorne 1983; Dunbar 1984; Elgin Courier 1984b, 1984e) concerning 13 remaining burials, which were unmarked and unidentified (Graves I-U), described nine individuals, specifically--Beatrice Finnagin, Virginia E1 izabeth Hewitt Bigger, Mable Elizabeth Dunbar, Barney Elbert Dunbar, Junior Dunbar, Baby Dunbar, a Mexican woodcutter, the King infant, and the infant of a transient family. By age groups, these reported individuals total three adults, one male and two females; one female child; and five infants, two male and three of unknown sex.

A comparison of Massey's (Appendix A) findings for the unmarked graves (Graves I-U) with data from the funeral home records and from informants' descriptions of specific individuals shows that three adults were recovered from unmarked graves, which correlates with the total of three adults mentioned in records and accounts, for which the grave associations are unknown. Only one unmarked child burial was recovered, and one child was mentioned in the funeral home records. Nine unidentified infant burials were recovered, but only five infants for which the grave locations were unknown were reported.

Styles of grave decoration, coffin form, and materials used in some of the unmarked burials may indicate whether they date to the early or late period of utilization of the cemetery. The handmade brick crypt with shell decoration which overlies Grave $E$ may indicate that it is an early burial. The hexagona 1 cherry wood coffin, an earlier form, and the rough cut vau $1 t$ planks in Grave $U$ may indicate that it is also one of the earlier burials in the cemetery. The cherry wood and other hardwood coffins (Graves C, H, R, T, and $U$ ) identified by Holloway (Appendix B) may also mark the earlier coffins at the site, though it might rather be a sign of affluence, or indicate a 
particular craftsman. The location of Morgan Chapel Cemetery and the styles of burials which were recorded are quite similar to other cemeteries and burials throughout the rural South.

We believe that the participation of archaeologists in the relocation of historic cemeteries is worthwhile, and can result in the recovery of much information concerning the health, mortuary customs, and attitudes toward death of historic peoples. The information gained from Morgan Chape 1 Cemetery illustrated burial customs during the turn of the century, including the usage of wooden coffins, some of which were handmade, glass fronts on coffins, possibly shrouds or winding sheets, and wooden vaulting. This project in particular also demonstrated some of the difficulties in public relations, legal matters, and methodology which archaeologists are likely to face during the recovery of historic burials.

Morgan Chape 1 Cemetery (41 BP 200) is no longer considered by the archaeologists to be a significant cultural resource, based upon the 1 ack of remaining in situ cultural deposits and features at the site. It is suggested, therefore, that the cemetery not be recommended for nomination as a State Archeological Landmark, or for the National Register of Historic Places.

\section{GLOSSARY}

bonding: The process of pressing fibers into sheets or webs that are he1d together by adhesive.

burial goods: Personal effects placed with a burial.

casket: A term that may refer to a rectangular burial receptacle with perpendicular sides which came into style after 1850 (McReynolds 1981a:93, citing Coffin 1976:101, 1981b:65; Blake1y and Beck 1982:188).

canted: A sianted edge or surface. In this report, canted is used to describe the corners of coffins and glass fronts which were angled. Some reports may use the term mitered instead of canted.

coffin: A term which may refer to hexagonal, or truncated, burial receptacles (McReynolds 1981a:93, citing Coffin 1976:101, 1981b:65). In this report, coffin refers to burial receptacles of various shapes, not just hexagonal forms.

coffin box: A thin wooden receptacle which served as a vault, containing the coffin.

composition: An early form of plastic.

cupreous: Any of various metal alloys, such as brass, containing high percentages of copper.

dug vault: A burial chamber formed by digging a narrow pit the size of the coffin in the bottom of the wider grave pit (Clark 1974:232). 
ear piece: The part of a coffin handle that attaches to the coffin, and is located on either end of the actual handle section (McReynolds 1981b:65, citing Rogers and Bros. 1882).

false crypt: A structure built over subsurface burials that does not contain the corpse but rather serves as a permanent grave mound (Jordan $1976: 154,1982: 18$ ).

family plot: An area reserved within a cemetery for members of a family group.

gesso: A mixture of plaster of Paris and glue, often used to prepare a surface for painting.

glass front: A cut glass plate, which might be of various forms, placed on top of the upper part of a coffin to provide a viewing window of the corpse. Also referred to as a glass sealer or a bust window (McReynolds 1981a:93, citing Coffin 1976:101, 1981b:15, 43; Blake1y and Beck 1982:188-189, 199-200, citing K 1 ine and $K 1$ ine n.d., Combes 1972, and Dickens and B1ake1y 1979).

grave mound: Elongated earthen mounds which overlie graves.

laminating: Joining layers of cloth together with such substances as glue or resin to form one fabric.

lime: Calcium oxide, a white caustic lumpy powder sometimes used for waste treatment, or any of various forms of calcium oxide differing chiefly in water content and percentage of such materials as silica, alumina, and iron; also called lime, quicklime, unslaked lime, or calx.

nonwoven fabric: This term is used in this report to denote a fabric made of parallel threads bonded in some fashion and applied as a decorative finish to the outside of a coffin.

plain weave: A weave in which the weft thread passes over one warp thread, then under the next, alternating across the cloth.

Dlaque: A metal plate attached onto the upper part of the coffin 1 id. These p 1 aques were often ornate and were inscribed with sayings such as "OUR DARLING" or "AT REST."

scraped cemetery: Cemeteries cleared of vegetation; also referred to as bare earth cemeteries (Jordan 1976:153-154, 1980:234, 1982:14-16).

shroud: A cloth used to wrap a corpse for burial; also referred to as a burial robe or a winding sheet (C1 ark 1974:234-236; Fox 1984:53).

studs: Ornamental metal tacks attached to the coffin exterior (McReynolds 1981b:65, citing Rogers and Bros. 1882). 
thumbscrews: A vertical piece of coffin hardware used in conjunction with a horizontal screw plate to fasten down the coffin 1 id or the coffin box 1 id (McReynolds 1981a:65, citing Rogers and Bros 1882). In th is report, thumbscrew refers to both the screw plate and thumbscrews since both items were consistently used together on the Morgan Chapel Cemetery coffins.

twilled weave: A weave in which the weft threads are inter laced with the warp to produce a diagonal pattern across the fabric, creating a stronger, heavier fabric than a plain weave.

vault: A burial chamber, especially when underground.

vault planking: Wooden planks placed across the shelf or step of the grave pit formed by the dug vau1t (C1ark 1974:232); also referred to as grave arches (B1akely and Beck 1982:188; Fox 1984:49).

vertisols: Generally, clayey soils with low hydraulic conductivity, and a high content of swelling clay. Deep, wide cracks are formed when vertisols are partially dried. At Morgan Chapel Cemetery, the surface horizons were stongly self-mulching (Soil Survey Staff 1975:375-377, 428).

volunteer: Refers to plants that are self-sown or have reseeded themselves. In this report, this term refers to irises which have perpetuated themselves long after they were originally planted.

warp: The thread that runs lengthwise in a woven fabric.

weft: The thread that runs crosswise in a woven fabric.

white metal: Any of various whitish alloys containing high percentages of tin or lead, such as pewter; or possibly zinc.

z-twisted: A right-hand twisted thread, one in which the twist is away from you and the fibers 1 ie from the upper right to the lower left across the thread. 
Aliaga, G. R.

1984 Identification of Wood Samples from Two Cemeteries in the Choke Canyon Reservoir. Appendix I in A Study of Five Historic Cemeteries at Choke Canyon Reservoir, Live Oak and McMul1en Counties, Texas, by A. A. Fox:59-68. Center for Archaeological Research. The University of Texas at San Antonio, Choke Canyon Series 9.

Arbingast, $S_{0} A_{0}$, L. G. Hennamer, R. H. Ryan, A. Lo, D. L. Karney, C. P. Zlatovich, M. E. Bonine, and R. G. Steele

1973 At1as of Texas. Bureau of Business Research, The University of Texas at Austin.

\section{Austin American-Statesman}

1984 Removal of Remains Stirs Protest at But1er Cemetery. August $7: 1$. Austin, Texas.

The Bastrop Advertiser \& County News

1984 a Cemetery Move Stirs Protest. August 9:1, 4. Bastrop, Texas.

1984b More Graves C1aimed at Site. September 6:Il, II10. Bastrop, Texas.

The Bastrop County Times

1984 The Dead Now, Next Come the Living. August 16:A2. Smithvi11e, Texas.

Bennett, R. A.

1968 Dawson County Historical Burial. Transactions of the Fourth Regional Archeological Symposium for Southeastern New Mexico and Western Texas 78.

Biggers, $\mathrm{J}$.

1984 Personal communication with A. J. Taylor. August 8. Personal field journal for the CPS-Butler Project, Phase III. On file at the Center for Archaeological Research, The University of Texas at San Antonio.

B1akely, R. L. and J. A. Beck

1982 Bioarchaeology in the Urban Context. In Archaeology of Urban America: The Search for Pattern and Process, edited by R. S. Dickens, Jr.:175-207. Academic Press, New York. 
Brown, K. M.

1983 Personal field journal for the CPS-Butler Project, Phase III. July 8. On file at the Center for Archaeological Research, The University of Texas at San Antonio.

1986 Archaeological Studies at the CPS Butler Lignite Prospect, Bastrop and Lee Counties, Texas 1983. Center for Archaeologica 1 Research. The University of Texas at San Antonio, Archaeological Survey Report 140.

Bureau of Economic Geology

1974 Geologic Atlas of Texas. Austin Sheet. Bureau of Economic Geology, The University of Texas at Austin.

Carter, E. S. and C. S. Ragsdale

1976 Biegel Settlement: Historic Sites Research, Fayette Power Project, Fayette County, Texas. Texas Archeological Survey, The University of Texas at Austin, Research Report 59.

Casey, E. (Mrs. J. Casey)

1980 Personal communication with E. Roemer, Jr. July 11. Personal field journal for the CPS-Butler Survey, Phase I. On file at the Center for Archaeological Research, The University of Texas at San Antonio.

1984 Personal communication with A. J. Taylor. September 6. Personal field journal for the CPS-Butler Project, Phase III. On file at the Center for Archaeological Research, The University of Texas at San Antonio.

Clark, S.

1972 The Decoration of Graves in Central Texas with Seashel15. In Diamond Bessie and the Shepherds, edited by W. M. Hudson:3343. Publications of the Texas Folk lore Society 36 . Encino Press, Austin.

Clark, T. D.

1974 Pills, Petticoats, and Plows: The Southern Country Store. University of Ok lahoma Press, Norman.

Coates Field Service Files

1974- Fayette Power Project Files 1974-1975. Deposited with the 1975 Lower Colorado River Authority, General Offices. Austin, Texas. 
Coffin, M. M.

1976 Death in Early America. Thomas Nelson, Inc., Nashvilile.

Col1 ins, M. B., T. R. Hester, and T. S. E1 1 zey

n.d. Excavations at Resaca de la Palma, A Mexican War Cemetery Site (41 CF 3), Cameron County, Texas. Notes on file at the Texas Archeological Research Laboratory, The University of Texas at Austin.

Combes, J. D.

1972 Ethnography, Archaeology, and Burial Practices Among Coastal South Carolina Blacks. The Conference on Historic Site Archaeology Papers 7:52-61.

Creel, L.

1984 Personal communication with A. J. Taylor. August 6. Personal field journal for the CPS-Butler Project, Phase III. On file at the Center for Archaeological Research. The University of Texas at San Antonio.

Deetz, J.

1977 In Sma11 Things Forgotten, The Archeology of Early American Life. Anchor Press/Doubleday, Garden City, New York.

Dickens, R. S., Jr. and R. L. Blakely

1979 Preliminary Report on Archaeological Investigations in Oak 1 and Cemetery, Atlanta, Georgia. The Conference on Historic Site Archaeology Papers 13:286-314.

Dunbar, H. D.

1984 Personal communication with A. J. Taylor. August 8, 16, 24. Personal field journal for the CPS-Butler Project, Phase III. On file at the Center for Archaeological Research. The University of Texas at San Antonio.

\section{Elgin Courier}

1984a Cemetery Relocation Required for Mining. JuTy 14:10. Elgin, Texas.

1984b Methodist Cemetery Relocation Underway. August 9:1, 5, 15. Elgin, Texas.

1984c Excavations Continue at Methodist Cemetery. August 16:8. Elgin, Texas. 
Elgin Courier (continued)

1984d Methodist Cemetery Excavations Continue. August 23:10. Elgin, Texas.

1984e Judge Halts Work at Morgan Chapel. September 6:1, 4. Elgin, Texas.

Farberow, N. L., editor

1975 Suicide in Different Cultures. University Park Press, Baltimore.

Ferguson, B.

1983 Final Report on the McGee Creek Cemetery Relocations, Atoka County, Ok 1 ahoma. Bureau of Reclamation, McGee Creek Project, Farris, Ok 1 ahoma.

Fox, A. A.

1984 A Study of Five Historic Cemeteries at Choke Canyon Reservoir, Live Oak and McMullen Counties, Texas. Center for Archaeological Research. The University of Texas at San Antonio, Choke Canyon Series 9.

Fox, A. A. and K. Livingston

1979 Historical, Architectural and Archaeological Investigations at the Steiner-Schob Complex, Victoria County, Texas. Center for Archaeological Research. The University of Texas at San Antonio, Archaeological Survey Report 52.

Fox, D. E.

1983 Traces of Texas History: Archeological Evidence of the Past 450 Years. Corona Pub 1 ishing Company, San Antonio, Texas.

Freeman, M. D. and W. B. Fawcett, Jr.

1980 The Antebellum Period in the Stephen F. Austin Colony: Historical and Archeological Research in the Palmetto Bend Reservoir Area, Jackson County. Texas. Part 1: The Suther 1 and Plantation and the Alabama Settlement: A Study in Cluster Migration (by Freeman); Part 2: Archeological Investigations at Historic Sites (by Fawcett). Texas Archeological Survey, The University of Texas at Austin. Research Report 70, Palmetto Bend Reservoir Series 5. 
French, S.

1974 The Cemetery as Cultural Institution: The Establishment of Mount Auburn and the "Rural Cemetery" Movement. In Death in America, edited by D. E. Stannard:69-9l. University of Pennsylvania Press, Philadelphia.

Gilmore, K. K.

1969 The San Xavier Mission. A Study in Historical Identification. State Building Commission, Archeological Program, Report 16.

Gould, F. W.

1969 Texas Plants--A Checklist and Ecological Summary. The Texas A\&M University System. Texas Agricultural Experiment Station, College Station.

Harmer, R. M.

1963 The High Cost of Living. The Crowe11-Collier Press, New York.

Herrington, L. and M. J. McReynolds

1981 A Preliminary Analysis of Skeletal Remains from the Laredo Cemetery Site. Appendix II in Archeological Investigations at the Laredo Cemetery Site (41 WB 22), Webb County, Texas, by M. J. McReynolds:78-82. Prewitt and Associates, Inc.s Reports of Investigations 11 . Austin, Texas.

Hester, T. R.

1968 Notes on Some Historic Indian Artifacts Found near Ozona, Texas. Newsletter, Midland Archeological Society (June):2-4.

1978 The Archaeology of the Lower Rio Grande Valley of Texas. In Proceedings: An Exploration of a Common Legacy: A Conference on Border Architecture, project director M. E. Heck:66-73. Texas Historical Commission, Austin.

$\mathrm{Hi} 11, \mathrm{D}$.

1968 Magic and Superstition. Hamlyn Publishing Group, Ltd., London.

Hoerman, V. (Mrs. N. W. Hoerman)

1980 Personal communication with Erwin Roemer, Jr. July 11. Personal field journal for the CPS-Butler Survey, Phase I. On file at the Center for Archaeological Research, The University of Texas at San Antonio. 
Jordan, T. G.

1976 Forest Folk, Prairie Folk: Rural Religious Cultures in North Texas. Southwestern Historical Quarterly 80(2):135-162.

1980 "The Roses So Red and the Lilies So Fair": Southern Folk Cemeteries in Texas. Southwestern Historical Quarterly $83: 227-258$.

1982 Texas Graveyards: A Cultural Legacy. University of Texas Press, Austin.

Kelly, T. C. and L. Highley

1979 The Jackpump Project. An Archasological Survey of Portions of Karnes and Gonzales Counties, Texas. Center for Archaeological Research, The University of Texas at San Antonio, Archaeological Survey Report 65.

Kelly, T. C. and E. Roemer, Jr.

1981 Archaeological and Historical Investigations in Bastrop and Lee Counties. Texas. Center for Archaeological Research, The University of Texas at San Antonio, Archaeological Survey Report 101.

Kitlen, Mrs. J. C., editor

1974 History of Lee County, Texas. Nortex Press, Quannah.

$\mathrm{K} T$ ine, K. and $\mathrm{J}$. Kline

n.d. The Meaning and Value of the Casket. Brochure of the Casket Manufacturers Association of America. Evanston, I11inois.

LeVine, F. and M. D. Freeman

1982 A Study of Documentary and Archeological Evidence for Comanchero Activity in the Texas Panhandle. Manuscript on file at the Texas Historical Commission, Austin.

Lewis, D. R.

1984 Personal communication with A. J. Taylor. Center for Archaeological Research, The University of Texas at San Antonio.

Massey, V. K.

1984 Letter written to A. J. Taylor concerning Morgan Chapel Cemetery. Department of Anthropology, Texas A\&M University, College Station. October 26. On file at the Center for Archaeological Research, The University of Texas at San Antonio. 
McCrary, M. (Mrs. G. B.)

1955 Golden Anniversary 1905-1955. (No publisher given. It is a history of the Elgin Methodist Church, Elgin, Texas.)

McIntire, J. E.

1984 Personal communication with A. J. Taylor. August 14. Personal field journal for the CPS-Butler Project, Phase III. On file at the Center for Archaeological Research. The University of Texas at San Antonio.

McReynolds, M. J.

1981a A Brief History of Coffins. Appendix IV in Archeological Investigations at the Laredo Cemetery Site (41 WB 22), Webb County, Texas, by M. J. McReynolds:92-96. Prewitt and Associates, Inc.s Reports of Investigations 1l. Austin, Texas.

1981b Archeological Investigations at the Laredo Cemetery Site (41 WB 22), Webb County, Texas. Prewitt and Associates, Inc., Reports of Investigations 11. Austin, Texas.

McWilliams, B.

1984 Personal communication with A. J. Taylor. August 24, 28. Personal field journal for the CPS-Butler Project, Phase III. On file at the Center for Archaeological Research, The University of Texas at San Antonio.

Miller Funeral Home Records

1911- On file at the Newby Funeral Home, Elgin, Texas. 1950

Moorman, E. H. and E. B. Jelks

1953 Field journal of survey of Inspiration Point, Turkey Creek, and DeCordova Bend Reservoir; August 24, 1953. Notes on file at the Texas Archeological Research Laboratory, The University of Texas at Austin.

Morris, D.

1975 Interview conducted by Crystal Ragsdale concerning the relocation of burials from family cemeteries at Biegel's Settlement. La Grange, Texas. 
Newby, M. L.

1984 Letter written to A. J. Taylor concerning the Miller Funeral Home. Newby Funeral Home., Inc., Elgin, Texas. November 15. On file at the Center for Archaeological Research. The University of Texas at San Antonio.

Newcomb, W. W., Jr.

1958 The Skeleton of Yellowhouse Canyon. Texas Memorial Museum, Museum Notes 8. Austin.

Odiorne, J.

1983 Letter written to K. Brown concerning Morgan Chape 1 Cemetery. Odiorne and Odiorne, Attorneys at Law, Austin. Texas. July 22. Photocopy on file at the Center for Archaeological Research, The University of Texas at San Antonio.

01 msted, F. L.

1978 A Journey Through Texas, Or, A Saddle Trip on the Southwestern Frontier. University of Texas Press. Barker Texas History Center, Series 2. Reprint of the 1857 edition published by Dix, Edwards, New York.

Parsons, M. L.

1967 Archeological Investigations in Crosby and Dickens Counties, Texas, During the Winter, 1966-1967. State Building Commission, Archeological Program, Report 7.

Phelps, D. S., editor

1979 An Archaeological-Historical Study of the Bryan Cemetery and Site 31 CV 25, Simmons-Nott Airport, New Bern, North Carol ina. North Carolina Archaeological Council Publication 10. Raleigh.

Pool, W. C.

1975 A Historical Atlas of Texas. Encino Press, Austin.

Puck le, B. S.

1926 Funeral Customs: Their Origin and Development. T. Werner Laurie Ltd., London.

Ray, C. N. and E. B. Jelks

1964 The W. H. Watson Site: A Historic Indian Burial in Fisher County, Texas. Bulletin of the Texas Archeological Society 35:127-141. 
Roberts, B.

1950 Springs From The Parched Ground. Hornby Press, Uvalde, Texas. Robertson, J. I., Jr.

1984 Tenting Tonight: The Soldier's Life. Time-Life Books Series, The Civil War. Time-Life Books, Alexandria, Virginia.

Rogers, C. and Bros.

1882 Descriptive Catalog of Coffin and Casket Trimmings. Springfield Printing Co., Springfield, Massachusetts.

Rogers, K. and M. J. McReynolds

1981 Identification of Wood Used in Coffin Construction, the Laredo Cemetery Site. Appendix III in Archeological Investigations at the Laredo Cemetery Site (41 WB 22), Webb County, Texas, by M. J. MCReynolds:84-89. Prewitt and Associates, Inc., Reports of Investigations 11 . Austin, Texas.

Schuetz, M. K.

1968 The History and Archeology of Mission San Juan Capistrano, San Antonio, Texas. Volume 1 (of 2 volumes). State Building Commission, Archeological Program, Report 10. Austin, Texas.

1969 The History and Archeology of Mission San Juan Capistrano, San Antonio, Texas. Volume 2 (of 2 volumes). State Building Commission, Archeological Program, Report 10.

1974 The Dating of the Chapel at Mission San Juan Capistrano. Texas Historical Comnission. Special Report 12.

Soil Survey Staff

1975 Soil Taxonomy: A Basic System of Soil Classification for Making and Interpreting Soil Surveys. United States Department of Agriculture, Soil Conservation Service, Agriculture Handbook 436.

Soute, $C$.

1984 Personal communication with A. J. Taylor concerning the elevations of the graves at Morgan Chapel Cemetery which were recorded by Barry White, independent surveyor, hired by City Public Service of San Antonio, Texas. November 21. Notes on the elevations taken during a phone conversation, on file at the Center for Archaeological Research. The University of Texas at San Antonio. 
Stuard, A.

1984 Personal communication with A. J. Taylor. August 5. Personal field journal for the CPS-Butler Project, Phase III. On file at the Center for Archaeological Research. The University of Texas at San Antonio.

Suhm, D. A.

1962 The White Site: A Historic Indian Burial in Yoakum County, Texas. Bulletin of the Texas Archeological Society 32:85-119.

Taylor, A. J.

1975a A Report on the Long Hollow Burial Site. Photocopy of manuscript on file at the Texas Archeological Research Laboratory, The University of Texas at Austin.

1975b Funeral Customs in the Caprock Area of the Texas Panhandle. Paper prepared for Dr. Don Cook, Way 1 and Baptist College, Plainview, Texas. Photocopy of manuscript on file at the Center for Archaeological Research. The University of Texas at San Antonio.

Texas Historical Commission

1981 Guidelines for Archeological Investigation of Mining Areas in Texas. Office of the State Archeologist, Texas Historical Commission, Austin.

United States Department of Agriculture

1979 Soil Survey of Bastrop County, Texas. United States Department of Agriculture, Soil Conservation Service, in cooperation with Texas Agricultural Experiment Station. Washington, D.C.

Weaver, J.

1984 Personal communication with A. J. Taylor. August 24. Personal field journal for the CPS-Butler Project, Phase III. On file at the Center for Archaeological Research, The University of Texas at San Antonio.

Webb, W. P., editor-in-chief

1952 The Handbook of Texas. 2 vols. The Texas State Historical Association, Austin. 
Whilden, B. and K. Cox

1973 01d-Time Burials. In Foxfire 2, edited by Eliot Wigginton:304-323. Anchor Press/Doubleday, Garden City, New York.

Wigginton, E., editor

1973 Foxfire 2. Anchor Press/Doubleday, Garden City, New York.

Willis, R. E.

1984 Letter written to I. W. Cox concerning burial practices. Decker United Methodist Church, Austin. Texas. On file at the Center for Archaeological Research. The University of Texas at San Antonio.

Wittkofski, J. M.

1984 Current Research: Mid-Atlantic. Pennsylvania: First African Baptist Church Cemetery, Philadelphia. The Society for Historical Archaeology, Newsletter 17(3):24-25.

Word, J. H. and A. A. Fox

1975 The Cogdel1 Burial in Floyd County, Texas. Bulletin of the Texas Archeological Society 46:1-64. 


\title{
APPENDIX A
}

\section{AN OSTEOLOGICAL ANALYSIS OF THE BURIALS FROM MORGAN CHAPEL CEMETERY}

\author{
Virginia K. Massey
}

An osteological analysis was requested for the skeletal remains from the Morgan Chapel Cemetery in order, first, to ensure that the individuals in marked graves could be properly identified for reburial, and second, to provide information about deceased persons in unmarked graves in the hope that they too might be identified. In both cases, data was sought about age, sex, size, and any other physical attributes that might be of use to family members (LaVerne Herrington. Texas Historical Commission [THC], personal communication with Jack Eaton). Additional1y, the THC suggested that information be sought which would illuminate the health conditions of the past population or provide information about early Texas communities.

A study of this kind has a value not 1 imited to the immediate project. Although at first glance it may appear on 1 y to describe the individuals buried in a particular graveyard, the information might 1 ater be combined with that derived from other cemeteries in the area or from the same time period to portray the 1 arger population. We would then be ab 1 e to address questions about the living community, and perhaps its afflictions, as wel1. Did women 1 ive longer than men? What ages were most dangerous for children? Was severe malnutrition widespread, and at what ages were most individuals vulnerable to it? For a 11 these inquiries, mortuary data can help supply answers.

In order to achieve these ends data was sought about the following characteristics of each individual: sex, age at death, stature, and pathology. Traits evaluated were those which could be assessed in the field in a 1 imited amount of time and considering the state of preservation of the bone. Sex was determined in adult individuals where possible by the following criteria: rugosity of the sku11, mandible, and postcranial skeleton (Krogman 1962; Bass 1971; Stewart 1979; Brothwe11 1981); size and shape of the pelvis (Krogman 1962; Bass 1971); and by discriminant function analys is of the talus and calcaneus (Steele 1976). Evaluation of sex was not attempted for subadults because reliable indicators of gender do not appear on immature disarticulated skeletons. Age was determined, in subadults, 1 argely by comparing their tooth development with that portrayed in Schour and Massler's (1944) chart. Further indicators of age in subadults which were evaluated are the fusion of vertebral elements and of certain bones of the cranium. Indicators of advancing age in adults consisted of premortem tooth 10 ss, dental attrition, and signs of arthritis on the articular surfaces of bones. The pathologies noted were dental disease, arthritis, signs of fracture or other injury to bone, and any signs of infection. Selected skeletal elements were also examined for porosity, and the parietal bones were evaluated for the thinning which sometimes accompanies old age, but these traits were not found.

Many of these traits can be noted on $1 y$ in relatively undamaged skeletons. Here preservation was expected to be good, because the burials were less than 100 years $01 d$, and good preservation of bone was noted at the slightiy older 
Choke Canyon cemeteries (Fox 1984). Unfortunately, the actual condition of bone recovered from this graveyard was disappointingly poor. In several of the infant burials, only traces of bone were present; in others, only smal1 fragments were preserved. Adult burials were better preserved, because adult bone is heavier and more mineralized, yet even these were extensively eroded because of the local soil conditions. Often bone could be seen in the soil but was too eroded to be removed intact. The articular ends of most long bones had long since disintegrated. The relatively fragile pubic portion of the innominate, from which can be derived the most reliable evidence in adults for age (McKern and Stewart 1957; Gilbert and McKern 1973) as we11 as sex, was not preserved in any burial.

The results of the unexpectedly poor preservation were diminished certainty where sex was to be assigned and reduced precision in age assessment. The age of adults between 17 and 40 or 50 could have been estimated in increments of two to twenty years by using information from the pubic symphysis. But here, because no pubic symphyses were preserved, our best indicators of age were dental attrition and premortem tooth 10s5, which informed of only two age categories: adult and old adult. Fortunately, the best indicators of subadults' age at death, teeth and tooth buds, were recovered from several of these burials. Age estimates for subadult individuals in burials where no teeth were preserved were derived from other sources such as the size of the coffin or the size and texture of the bone.

Indicators of sex in the skeleton stem from the childbearing capacity of the female pelvis and the greater muscular development of the male. Since no complete pelves were preserved, rugosity of the skeleton was the best indicator of sex. In the cranium, traits considered male were obliteration of frontal and parietal eminences, larger mastoid processes, a more pronounced external occipital protuberance, zygomatic crests extending posteriorly over the external auditory meatus, more rounded orbital rims, more pronounced browridges and more protuberant glabe $11 \mathrm{a}$. The male mandible generally has a square chin and everted gonial angles. The reverse of these traits occurs in the female cranium and mandible: frontal and parietal eminences are pronounced, the mastoid processes are smal1 er, the external occipital protuberance is smoother, the zygomatic crests end anterior to the external auditory meatus, the orbital rims are sharper, the brow ridges are smaller, and the glabella less protuberant. The female mandible tends to have a rounded or pointed chin and inverted gonial angles. Postcranially, marks of muscle attachment are more pronounced in the male than in the female. The male femoral head is larger, and the dimensions of the talus and calcaneus are distinctive enough that discriminant analysis can be used to distinguish up to $89 \%$ of male and female skeletons. The male innominate is heavier and has a larger acetabulum, while the female innominate is more likely to have a preauricular sulcus and an elevation of the sacroiliac articular surface.

Size of the individuals in this sample could not be calculated because none of the long bones were sufficiently complete. Even the best-preserved bones, from Burial $U$, 1 acked the 1 andmarks required to estimate their 1 engths from fragments (Steele 1970). Since calculation of stature is based on long bone lengths (Trotter and Gleser 1952), size could not be calculated with 
precision. However, subjective impressions of size were recorded in the hope that they may aid in the identification of unknown individuals.

Pathology looked for in these incomplete skeletons included dental disease and bone lesions. Common forms of dental disease are caries ("cavities") and loss of teeth before death. A less frequent type of dental pathology is ename 1 hypoplasia, characterized by pitted enamel, often with horizontal grooves, which results from a local growth disturbance while the enamel is being laid down on the developing tooth bud (Colby, Kerr, and Robinson 1971 ). A dental cary is known by a hole with rounded margins in the tooth. Premortem tooth 1 oss may be detected by resorption of alveolar bone. Final1y, subperiostea 1 bone deposition characterizes lesions in the bone itself.

Another difficulty encountered in examining the material concerned the length of time the skeletal material was available for study. The 1 aw required that al1 burials be covered by sundown. This meant that, for adult burials, most of the day would be spent excavating the burial and exposing the skeleton. The skeletal material could not be removed from the grave and studied until relatively late in the working day. If it had been necessary to re-inter the remains before sundown on the same day that they were excavated, much osteological data would have gone unrecorded and unanalyzed. Fortunately, through the kind cooperation of City Public Service, the Newby Funera 1 Home, and especially the home's representative, Mr. J. E. McIntire, the skeletal remains were 1 awful1y stored in the funeral home overnight. They were returned to the site every morning for as 1 ong as it took to complete the analysis, permitting study that approximated the thorough studies possible in the 1 aboratory. The one way in which the time 1 imitations most affected the thoroughness of the study concerned the 1 imited time which could be devoted to conserving the material in the field. If more time had been available to stabilize the bone in the field, then more complete skeletal material would have been available for analysis.

Table 5 summarizes the osteological findings from the Morgan Chapel Cemetery. There were 21 burials of which seven were adults, one was an adolescent, one was a young child, and 12 were infants. One adult was determined to be male, one was female, and one was probably male; for the rest sex could not be determined. More detailed descriptions of each burial follow.

GRAVE A

\section{William F. Cruse}

The skeletal remains of this individual identified as William F. Cruse were bad1y eroded, and only fragments were recovered. Much of the bone was covered with an adherent blackish material which could not be removed either by dry or wet brushing. Therefore, the surface condition of the bone could not be assessed for porosity or 1esions. Much of the skeleton was represented in fragments, including long bones, cranial, and dental remains. Miscel 1 aneous and unidentifiable fragments were also recovered. 
TABLE 5. A SUMMARY OF THE OSTEOLOGICAL FINDINGS FROM MORGAN CHAPEL CEMETERY

Grave Sex Age at Death $\quad \begin{gathered}\text { Headstone Identification } \\ \text { or Other Data }\end{gathered}$

\begin{tabular}{|c|c|c|c|}
\hline A & male & adult & William F. Cruse \\
\hline$B$ & female & adult & Ann M. Cruse \\
\hline $\mathrm{C}$ & unknown & $1-2$ years & (believed to be Baker child) \\
\hline D & no skeletal & remains recovered & Browning infant daughter \\
\hline$E$ & no skeletal & remains recovered & coffin ( 4 feet 9 inches) \\
\hline $\mathrm{F}$ & unknown & $<1$ year & Dasha Lee Johnson (daughter) \\
\hline G & unknown & adult & Carol ine Myers \\
\hline$H$ & unknown & adult & Jane Ivy \\
\hline I & unknown & 9 months \pm 2 months & - \\
\hline $\mathrm{J}$ & no skeletal & remains recovered & probably infant \\
\hline K & no skeletal & remains recovered & infant vault \\
\hline$L$ & unknown & 6 months \pm 2 months & young child \\
\hline M & unknown & 2 years \pm 6 months & - \\
\hline $\mathrm{N}$ & male (?) & adult & dorsal side up \\
\hline 0 & unknown & adult & trauma to femur \\
\hline$P$ & unknown & 6 months or less & - \\
\hline 0 & unknown & $12-15$ years & $\begin{array}{l}\text { adolescent } \\
\text { enamel hypoplasia }\end{array}$ \\
\hline $\mathrm{R}$ & unknown & newborn & - \\
\hline $\mathrm{S}$ & unknown & probably newborn & - \\
\hline $\mathrm{T}$ & unknown & infant & - \\
\hline$U$ & unknown & adult & very tall \\
\hline
\end{tabular}


Fortunately, the following material was recovered which permitted assessment of sex as male: the everted left gonial angle of the mandible, the broad epicondylar area of the distal humerus, the 1 arge 1 eft mastoid process, and a large partial acetabulum. Further, the long bone fragments appeared quite robust.

The nearly complete mandibular body was recovered in three fragments. A 1 eft molar remained in the jaw; its size and position suggested that it was a third molar. It was very worn obliquely, the occlusal surface reduced to the surface of the bone at its distal edge. Alveolar resorption indicated premortem $105 s$ of all other molars. Although no other mandibular teeth were recovered, the sharp outlines of six anterior partial alveoli signified that these teeth may still have been present at the time of death. The central portion of the mandible lacked the alveolar area, so it was difficult to determine which teeth these alveoli represent. One on the left side looked 1 arge enough to have held a canine; the others seemed too sma 11 . Loss of molars and some premolars may have resulted in drifting of the remaining teeth.

Premortem loss of five mandibular molars, and the extreme wear found on the remaining lower molar, suggest that this individual was an old adult at the time of death, as the headstone indicates.

\section{GRAVE B}

\section{Ann M. Cruse}

Most of this individual's skeleton, identified as Ann M. Cruse, was represented by fragments. Occipital and parietal fragments of the sku 11 , parts of the mandible, and several 100 se teeth were recovered. The teeth were five mandibular molars and two mandibular premolars. The presence of these teeth indicates that there could not have been extensive premortem tooth loss, at least in the mandible. These molars did have caries, though. Two of the lower molars have occlusal caries; one has a 1 arge lesion, and the other has three smal1 ones. A lower molar and a lower premolar had one interproximal cary each at the cemento-enamel junction. Another molar had an interproximal cary in the middle of that surface.

Calculus was present on the occlusal surfaces of three lower molars, suggesting an absence of chewing friction for some time before death. Mrs. Cruse's granddaughter, Ms. Glenna Dunigan, recal ls that her grandmother suffered from heart trouble and dropsy for some years before death, but Ms. Dunigan does not remember if her grandmother ate soft food or a normal diet during her last years. Another possibility is that the three teeth with calculus are from the same side and that Mrs. Cruse favored one side while chewing.

Both mastoids were present and their small size, compared to those found in Grave $A$, suggests that this individual was female, as indeed headstone and 1 iving relatives confirm. The teeth indicate that this individual was an adult at time of death, but age cannot be estimated more precisely. 
GRAVE C

Twelve teeth and tooth buds were recovered from Grave $C$ in addition to many smal 1 fragments of the cranium and long bone. Identifiable cranial fragments consisted of partial petrosal portions of each temporal.

It is fortunate that so many teeth were preserved, because the development of teeth can indicate the individual's age at death. Here, age has been estimated from Schour and Mass 1 er's (1944) chart at one or two years of age at time of death.

GRAVE D

Browning Infant

No remains were recovered from the Browning infant from Grave D.

GRAVE E

No skeletal remains were recovered from a child's burial in Grave $E$.

GRAVE F

Dasha Lee Johnson

The sparse remains of the individual in Grave $F$ consisted of fragments of eggshel 1-thin cranial bone, some of which appeared to be from the frontal. Since no teeth or tooth buds were recovered, age could not be assessed with much exactness, but the thinness of the cranial bone is consistent with an age at death of 1 ess than one year, as recorded on the headstone for this female infant.

GRAVE G

\section{Caroline Myers}

An outline of a skeleton was easily visible in the soil of Grave G, but the bone was so very fragile that much of the bone disintegrated when removal from the grave was attempted. Preservation was good for bones of the cranium but extremely poor for all else. No indicators of sex, and few of age, were preserved. Although traces of the innominates could be seen in situ, the pubic symphysis was not visible.

The shape of the mandible was not easy to determine, because the outer cortex was gone. Presence or absence of teeth could not be determined, although the central portion of the mandible was not as thin as edentulous mandibles commonly are. Further, the right mandibular fossa was not as shallow as one might expect in an edentulous skul1. 
A great deal of cranial bone was recovered in medium-sized fragments. No parietal thinning was seen. The bone surface was too obscured by dirt to determine porosity or degree of suture fusion.

Facial bone was badly disintegrated, and even the mandible could not be removed from the grave in recognizable fragments. Only two teeth were recovered, both right upper molars. These teeth showed 1 ittle wear and no caries. Their good condition suggests that other teeth were present at time of death but were not preserved.

The only indicator of age was a bit of 1 ipping seen on one vertebral centrum. Lipping is usually not seen on the vertebrae of young adults, but it does not indicate an exact age.

GRAVE H

Jane Ivy

The bones recovered from Grave $H$ were fragments of the cranium, a tibia, vertebrae, and an unidentifiable long bone, all poorly preserved. Neither jaws nor teeth were preserved.

None of the elements which could indicate gender, such as the innominates, the mandible, and the mastoid processes, were recovered. Nothing was found that could indicate age at death.

\section{GRAVE I}

The sparse skeletal remains of the individual in Grave I consisted of a fragment of the symphyseal portion of the mandible as well as a few long bone fragments, unidentifiable fragments, and teeth. The mandible contained three permanent tooth buds, the development of which suggests an age at death of nine months, plus or minus two months.

\section{GRAVE J}

Since no skeletal remains were recovered from Grave J, it was probably that of an infant or small child. Adult bone in this cemetery, although poorly preserved, did not seem to disintegrate entirely.

GRAVE K

No skeletal remains were recovered from Grave $K$, which is thought to be that of an infant or smal1 child because the vault is 34 inches long. 


\section{GRAVE L}

Grave $L$ was found to be that of a child placed in an extended position in a glass-topped coffin. Several fragments of long bone, the cranium, and the mandible were recovered. Dental remains consisted of a major part of the mandible and loose teeth. Development of the dentition suggests an age at death of six months, plus or minus two months. Other indicators of age were the basilar and left exoccipital portions of the occipital bone which were still unfused, signifying an age of five years or 1ess. The unfused neural arches suggest that the child was less than two years old at time of death.

\section{GRAVE M}

A glass-topped coffin was found in Grave M containing a child placed in an extended position with hands crossed at the waist. Portions of the right tibia and talus adhered to the glass when it was removed.

Fragments of many parts of the skeleton were recovered from this burial, including the cranium, some bones of the arm, ribs, the separate bones of the innominates, and some dental remains. These consisted of a segment of the mandibular symphysis which contained partial crypts. Also present was a fragment of the right ascending ramus, including part of the mandibular condyle. Several deciduous teeth and permanent tooth buds were recovered. The upper deciduous posterior premolar and the upper permanent molar buds had we11-formed Carabel1i's cusps. The lower molar buds had pronounced buccal pits. Dental development indicates an age at death of two years, plus or minus six months.

\section{GRAVE N}

The skeleton in Grave $N$ was found dorsal side up with the palate up and the disarticulated mandible on its side next to the skul1. Most of the bones of the skeleton were represented, at least by fragments. Articular ends were genera 11 y 1 ost, and the sacrum, metatarsals, and pedal phal anges were not recovered. Much of the skeleton, though visible in situ, disintegrated upon remova1. Many characteristics diagnostic of age and sex were unfortunately not seen: the mastoids were missing, the basicranium region containing the basilar suture could not be found, the pelvis was crushed, and the vertebral centra were not recovered. The chin, however, was quite robust in appearance, which may indicate that the individual was male. Preservation was not good enough to assess pathology of the bone.

The dental examination revealed no premortem tooth 1 oss and only slight wear. An osteological examination indicated that this individual was probably male, and that he may have been in the prime of 1 ife when he died.

Mr. J. E. McIntire, a mortician, believes that the unusual position of the body within the coffin was caused by falling and shifting during transport to the cemetery over bumpy roads. Another possibility is that the coffin could have been temporarily malpositioned when it was lowered into the grave. In 
either case, the coffin fel1 or shifted, and so did the body within it. Repositioning the coffin did not reposition the body.

An alternative explanation was offered by Mr. Arthur von Rosenburg of City

Pub 7 ic Service. He was informed by a resident that during the time period this cemetery was in use, it was the custom to bury suicides face down. Although the only known local suicide of this period was buried in the McDade Cemetery, it is possible that one was buried here, unrecorded and forgotten.

\section{GRAVE 0}

No cranial remains were recovered from Grave 0, and only a small part of the left ascending ramus of the mandible was preserved. Moreover, this burial had been disturbed, possibly by rodents, before excavation, and the bones were not in anatomical position. Fragments of postcranial bones were found, among them remnants of the left femur which showed signs of severe trauma. Unfortunately, no indicators of sex or age were recovered.

The left femoral shaft recovered bore at its medial distal end a 1 arge cylindrical deposit of smooth subperiosteal bone. This cylindrical deposit so dramatically altered the shape of the shaft that the specimen barely resembled a normal femur. On the unaltered portion of the distal femur shaft a boney spur approximately $15 \mathrm{~mm}$ long projected at a right angle and appeared to represent an ossified muscle attachment. Additional1y, the linea aspera showed signs of possible infection along its length. Based upon these observations, it seems 1 ikely that this individual suffered an injury to the left femur long enough before death for considerable healing to have occurred.

\section{GRAVE P}

Very 1 ittle bone was recovered from this burial in Grave P--just a few splinters and a part of a petrosa1. Six deciduous tooth buds were recovered, the development of which suggests an age at death of six months or less.

\section{GRAVE 0}

Only cranial remains were recovered from Grave 0 . Most mandibular permanent teeth, including buds for the third molars, were recovered as we1 $1 /$ as al 1 but the third molar buds of the maxillary dentition. Both upper central incisors showed pronounced shoveling. Very slight shoveling was seen on the upper lateral incisors. Uneven enamel and shallow hypoplastic 1 ines appeared on several teeth, suggesting interruptions in enamel development which may have been caused by severe 111 ness, malnutrition, or injury to the deciduous precursors. Also, the right lower first molar had a 1 arge occlusal cary, and smaller caries were present on the upper first molars.

The development of the teeth suggests an age at death of 12 to 15 years. Sex could not be determined. 
GRAVE R

The individual's remains in. Grave $R$ consisted of several deciduous tooth buds and small fragments of cranial bone. The development of the teeth indicates that the infant died at birth.

\section{GRAVE S}

Skeletal remains from Grave $S$ consisted of fragments of both petrosals, both humeri, part of a femur, and some unidentifiable fragments. No teeth were recovered from this infant buria1. The casket was on $1 y$ 29 inches 1 ong. The fine-textured, porous appearance of the bone and the size of the 1 ong bone fragments are consistent with an age assessment of newborn.

\section{GRAVE T}

Three small fragments of bone comprised the skeletal remains found in Grave T. These fragments were not identifiable, but the largest piece looked 1 ike part of a long bone end. The fragments were porous and had the appearance of infant bone.

\section{GRAVE U}

Most of the skeleton was represented in the preserved remains found in Grave $U$, albeit in 1 arge fragments. The calotte was complete but the face was gone. The mandible was represented by fragments which could be reconstructed to form a nearly complete corpus, although some of the alveolar portion was broken off.

It is ironic that this skeleton, which was better preserved than any other in this sample, should have shown such equivocal traits for sex and age at death. The long bones were gracile but quite long and obviously were from a very tall individual. The talus and calcaneus were unquestionably male by discriminant analysis, a method which can correctly distinguish up to $89 \%$ of male and female skeletons, yet one might expect the results to indicate male sex when the analysis is applied to very tall persons of either gender. The innominate, under ideal conditions a very good indicator of sex, 1 acked the female signs of a preauricular sulcus and an elevation of the sacroiliac articulation, and it had a masculine heaviness and robusticity, but its sciatic notch was of a moderate angle. The mandible was gracile and had a rounded chin; its 1 eft gonial angle was everted; the right, inverted. The cranium was gracile, but frontal eminences were not prominent. The mastoid processes were smal1, and the zygomatic crest ended anterior to the exterior auditory meatus.

As for indicators of age, the same uncertainty prevailed. The pubic symphysis was not preserved. The articular ends of bones were not sufficiently preserved to show signs of arthritis or its absence. There was considerable premortem tooth loss, but some of the remaining teeth showed very little wear. Age can only be assessed as adult. 
The only pathology seen was dental; resorbed alveolar bone in the mandibular fragments declare premortem tooth 10ss, but the extent of this loss is unknown because on $1 y$ part of the alveolar bone was recovered. Just two molars were recovered, one which was so extensively damaged by caries that only the enamel shel1 of two-thirds of the crown survived. The other molar, single-rooted, had occlusal caries but showed 1 ittle wear.

It is of course possible that some unknown pathology contributed at once to the great stature of this individual, to his or her dental disease, and to the androgynous qualities of the remaining skeleton.

\section{ACKNOWLEDGMENTS}

I wish to thank Dr. D. Gentry Steele for reading and commenting on this manuscript. His guidance was invaluable in the preparation of this report.

A special note of thanks goes also to Mr. J. E. McIntire, whose contributions so often exceeded his responsibilities as project mortician. His careful recovery of infant remains was especially valuable to this osteological study.

\section{REFERENCES CITED}

Bass, W.

1971 Human 0steology: A Laboratory and Field Manual of the Human Skeleton. Missouri Archaeological Society, Special Publications, Columbia, Missouri.

Brothwe11, D. R.

1981 Digging Up Bones. 3rd edition. Cornel1 University Press, Ithaca, New York.

Colby, R. A., D. A. Kerr, and H. B. G. Robinson

1971 Color Atlas of Oral Pathology. 3rd edition. J. B. Lippincott Co., Philadelphia.

Fox, A. A.

1984 A Study of Five Historic Cemeteries at Choke Canyon Reservoir, Live Oak and McMul 1 en Counties, Texas. Center for Archaeological Research. The University of Texas at San Antonio, Choke Canyon Series 9.

Gilbert, B. M. and T. W. McKern 
Krogman, W. M.

1962 The Human Skeleton in Forensic Medicine. Charles C. Thomas, Springfield.

McKern, T. W. and T. D. Stewart

1957 Skeletal Age Changes in Young American Males. Quartermaster Research and Development Command, Technical Report Ep-45. Natick, Massachusetts.

Schour, I. and M. Massler

1944 Development of the Human Dentition. 2nd edition. American Dental Association, Chicago.

Steele, D. G.

1970 Estimation of Stature from Fragments of Long Limb Bones. In Personal Identification in Mass Disasters, edited by $T$. D. Stewart:85-97. National Museum of Natural History, Smithsonian Institution, Washington, D.C.

1976 The Estimation of Sex on the Basis of the Talus and Calcaneus. American Journal of Physical Anthropology 45:581-588.

Stewart, T. D.

1979 Essentials of Forensic Anthropology. Charles C. Thomas, Springfield.

Trotter, M. and G. C. Gleser

1952 Estimation of Stature from Long Bones of American Whites and Negroes. American Journal of Physical Anthropology, new series 9:463-514. 


\section{APPENDIX B}

ANALYSIS OF WOOD REMAINS FROM THE MORGAN CHAPEL CEMETERY, 41 BP 200

Richard G. Holloway

\section{INTRODUCTION}

During recent excavations by personnel of the Center for Archaeological Research. The University of Texas at San Antonio (CAR-UTSA), for the relocation of Morgan Chapel Cemetery (41 BP 200), a total of 21 graves was located. Twenty-eight wood samples were collected from 18 (85.7\%) of the 21 graves. Of the wood samples, six (67.9\%) were designated as originating from vault planking, and $13(46.4 \%$ ) were from coffins (a11 the coffins at Morgan Chapel Cemetery were wooden). No notation was made in the field designating whether nine $(32.1 \%)$ of the wood samples were from vault planking or coffins, on $7 y$ the grave from which they were taken was noted. Since Grave 0 contained neither a coffin box or vault planking, the wood sample from Grave 0 is assumed to be from the coffin. The wood samples were bagged separately and sent to the Department of Anthropology at Texas A\&M University for analysis.

\section{METHODS AND MATERIALS}

The wood samples were slow 1 y dried at the Texas A\&M 1 aboratory to remove ground moisture. Fresh transverse surfaces were exposed by the "snap method" of Leney and Casteel (1975). Transverse sections provide the most diagnostic features for wood identification to the genus level and thus were used throughout this study. Comparisons of the transverse sections of the samples from Morgan Chapel Cemetery with published identification keys to wood anatomy such as those by Panshin and deZeeuw (1980), and Dale (1968), as well as with modern reference material available at Texas A\&M University, allowed identifications to the genus level. The results of this analysis are presented in Table 6 .

\section{RESULTS}

Wood samples were obtained of $\operatorname{six}(3 / .5 \%)$ of the 16 graves with dug vau 1 ts at the site. All of these vault planking specimens were composed of a species of Pinus ( $p$ ine).

Thirteen wood samples were taken of $11(28.6 \%)$ of the 21 coffins at Morgan Chape 1 Cemetery. Of the 13 samples of coffin wood, eight $(61.5 \%)$ were Pinus (pine). However, this represents only $\operatorname{six}(54.5 \%)$ of the 11 sampled coffins, since three samples were taken of the Grave A coffin wood. Three (23.1\%) samples, or 27.3\% of the sampled coffins, were composed of a hardwood which most closely resembled Prunus (cherry; Fig. $11, a, b$ ). The remaining two (15.4\%) coffin wood samples, or 18.2\% of the ll sampled coffins, could not be identified other than being composed of a hardwood (Angiosperm).

Of the nine wood samples unidentified as to whether they were of vault planking, a coffin box, or coffin wood, seven $(77.8 \%$ ) were composed of Pinus 
TABLE 6. RESULTS OF BURIAL WOOD ANALYSIS, 41 BP 200

\begin{tabular}{|c|c|c|c|c|c|}
\hline Grave & Sex & Age at Death & Vault Planking & Coffin Wood & $\begin{array}{c}\text { Sample } \\
\text { Location Unknown }\end{array}$ \\
\hline A & male & 81 years & - & Pinus (3 samples) & - \\
\hline B & female & 65.5 years & - & Pinus & Pinus \\
\hline $\mathrm{C}$ & unknown & $1-2$ years & - & $\begin{array}{l}\text { Not identified } \\
\text { (Angiosperm) }\end{array}$ & Pinus \\
\hline D & female & infant & - & - & Pinus \\
\hline$E$ & unknown & sub-adult & - & - & - \\
\hline $\bar{F}$ & female & $11-12$ months & - & - & unknown \\
\hline G & female & 71 years & - & Pinus & - \\
\hline $\mathrm{H}$ & female & 79 years & - & $\begin{array}{l}\text { Not identified } \\
\text { (Angiosperm) }\end{array}$ & - \\
\hline I & unknown & 9 months \pm 2 months & - & $=$ & - \\
\hline $\mathrm{J}$ & unknown & infant & - & - & Pinus \\
\hline K & unknown & infant & Pinus & - & Pinus \\
\hline L & unknown & 6 months \pm 2 months & - & - & cf. Salicaceae \\
\hline$M$ & unknown & 2 years \pm 6 months & Pinus & - & Pinus \\
\hline$N$ & male? & adult & - & - & - \\
\hline 0 & unknown & adult & - & Pinus & - \\
\hline$P$ & unknown & 6 months or less & - & Pinus & - \\
\hline Q & unknown & $12-15$ years & Pinus & Pinus & - \\
\hline $\mathrm{R}$ & unknown & newborn & Pinus & cf. Prunus & - \\
\hline $\mathrm{S}$ & unknown & probably newborn & - & Pinus & - \\
\hline $\mathrm{T}$ & unknown & infant & Pinus & cf. Prunus & - \\
\hline U & female? & adu $7 t$ & Pinus & cf. Prunus & - \\
\hline
\end{tabular}



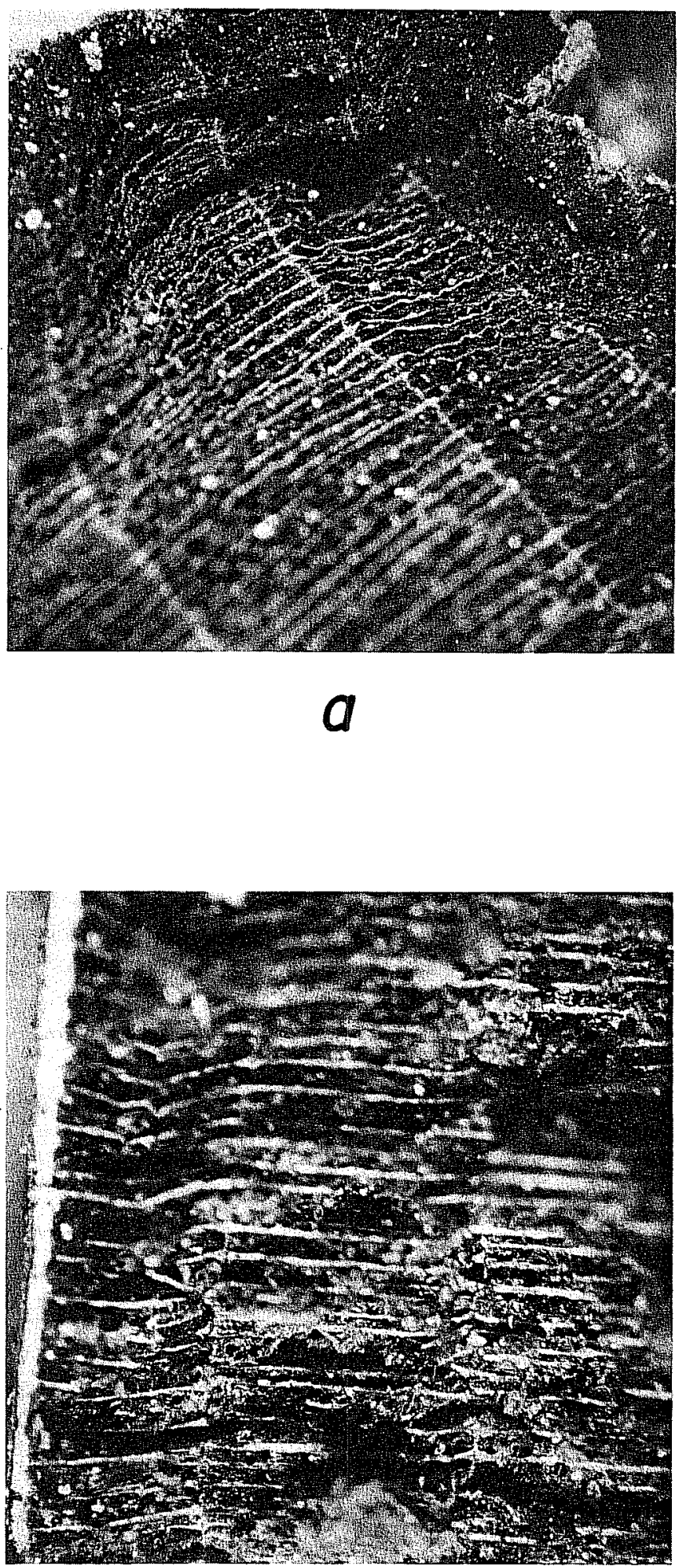

$b$

Figure 11. Microphotographs of the Coffin Wood Sample of cf. Prunus from Grave U. a, photographed at 300X; b, photographed at $400 x$. 
(pine). One (11.1\%) wood sample, Grave L, closely resembled Salicaceae which is the wi 110 family and includes pop 1 ar (Populus palmeri), quaking aspen (Populus tremuloides), and willow (Salix). The remaining wood sample could not be identified.

\section{COMMENTS}

Four (80\%) of the five sampled graves with hardwood coffins were those of infants; the fifth, Grave $U$, was an adu 1 t. Not al 1 the infants, however, were buried in hardwood coffins. Two infants, Graves $P$ and $S$, were buried in Pinus ( $p$ ine) coffins. Since only one of the graves (H) with a hardwood coffin was identified by a grave marker, there is no clear relationship between those individuals with hardwood coffins and those with pine coffins. It is interesting to speculate as to the causes for the variability in the types of coffin wood. Those individuals with hardwood coffins may be related, or infants below a certain age may have been afforded slightly different burial ceremonies or treatment. The 1 ater speculation, however, at this stage appears indefensible due to the variation and inconsistency of coffin wood types for infants and adults. At the present stage of knowledge concerning the individuals buried at Morgan Chapel Cemetery, though, we can only speculate.

REFERENCES CITED

Date, A.

1968 Comparative Wood Anatomy of Some Shrubs Native to the Northern Rocky Mountains. Research Paper INT-45. Ogden, Utah.

Leney, L. and R. W. Castee1

1975 Simplified Procedure for Examining Charcoal Specimens for Identification. Journal of Archaeological Science 2:153-159.

Panshin, A. J. and C. deZeeuw

1980 Textbook of Wood Techno?ogy. McGraw-Hi11, New York. 